\title{
An Archaeological Survey of a Portion of the Choke Canyon Reservoir Area in McMullen and Live Oak Counties, Texas
}

\author{
Alston V. Thoms \\ Department of Anthropology, Texas A\&M University \\ John L. Montgomery \\ Center for Archaeological Research \\ Alice W. Portnoy \\ Center for Archaeological Research
}

Follow this and additional works at: https://scholarworks.sfasu.edu/ita

Part of the American Material Culture Commons, Archaeological Anthropology Commons, Environmental Studies Commons, Other American Studies Commons, Other Arts and Humanities Commons, Other History of Art, Architecture, and Archaeology Commons, and the United States History Commons

Tell us how this article helped you.

This Article is brought to you for free and open access by the Center for Regional Heritage Research at SFA ScholarWorks. It has been accepted for inclusion in Index of Texas Archaeology: Open Access Gray Literature from the Lone Star State by an authorized editor of SFA ScholarWorks. For more information, please contact cdsscholarworks@sfasu.edu. 


\section{An Archaeological Survey of a Portion of the Choke Canyon Reservoir Area in McMullen and Live Oak Counties, Texas \\ Creative Commons License \\ (c) (1) (9)}

This work is licensed under a Creative Commons Attribution-NonCommercial 4.0 International License 


\title{
AN ARCHAEOLOGICAL SURVEY OF A PORTION OF THE CHOKE CANYON RESERVOIR AREA IN McMULLEN AND LIVE OAK COUNTIES, TEXAS
}

\author{
By \\ Alston V. Thoms, John L. Montgomery, and \\ Alice W. Portnoy \\ Report prepared by the \\ Cultural Resources Institute \\ Texas Tech University
}

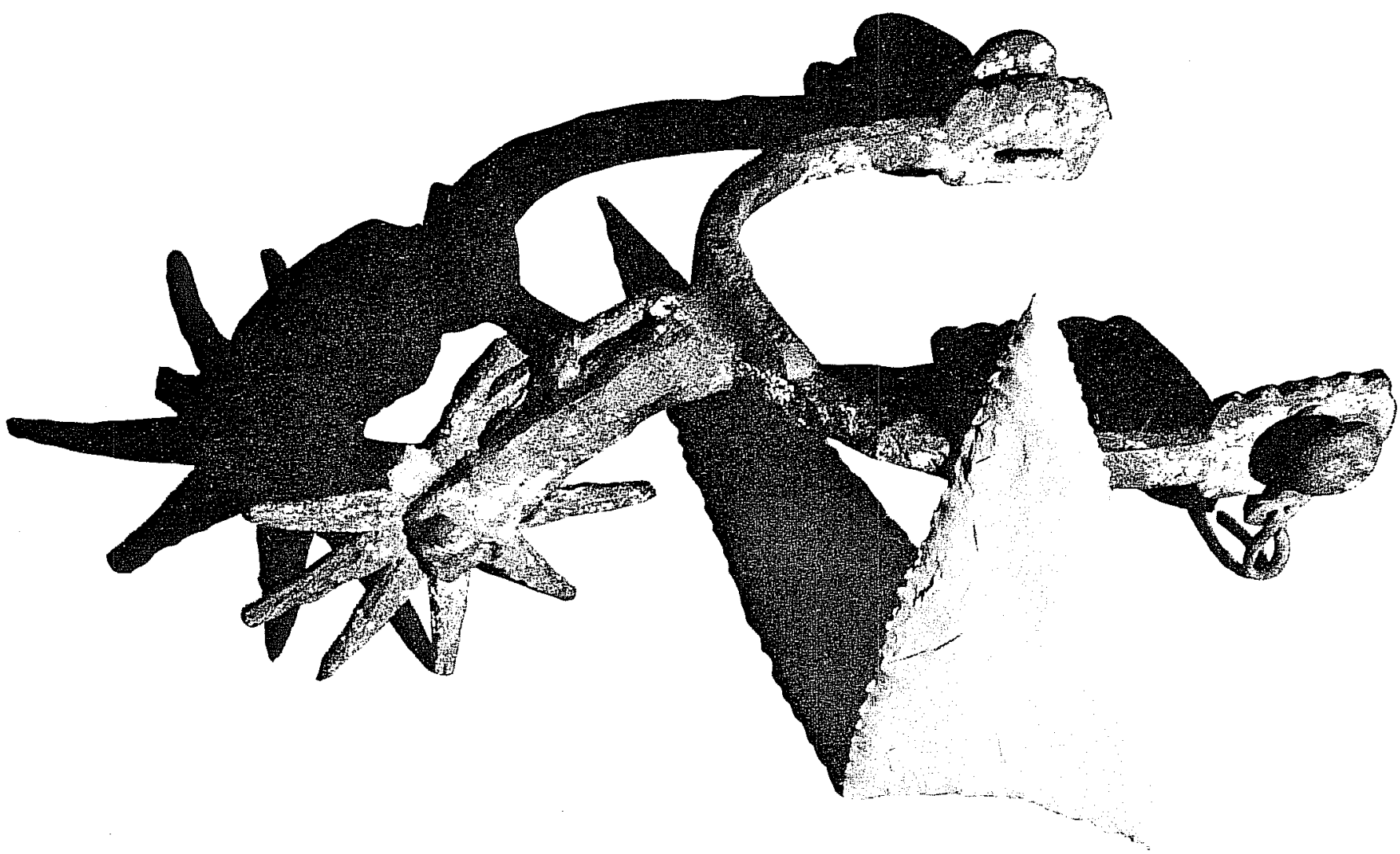

Center for Archaeological Research

The University of Texas at San Antonio

Choke Canyon Series: Volume 3 



\title{
AN ARCHAEOLOGICAL SURVEY OF A PORTION OF THE \\ CHOKE CANYON RESERVOIR AREA IN \\ McMULLEN AND LIVE OAK COUNTIES, TEXAS
}

by

Alston V. Thoms, John L. Montgomery, and Alice W. Portnoy

\author{
Report prepared by the \\ Cultural Resources Institute \\ Texas Tech University
}

Center for Archaeological Research

The University of Texas at San Antonio

Choke Canyon Series: Volume 3 



\section{ABSTRACT}

An intensive cultural resource survey was carried out on approximately 2544 hectares (6285 acres) of the proposed Choke Canyon Reservoir by the Cultural Resources Institute (CRI) of Texas Tech University from August through October 1977. The project was undertaken in response to needs of the Bureau of Reclamation. This report is one of a multivolume study.'concerning the area's cultural resources. During the 1977 survey, 113 archaeological sites, 42 low density artifact scatters, and five isolated finds were located and recorded. A no-collection policy was maintained, except isolated finds. In the late fal1 1977, 15 of the recorded sites were subjected to 1 imited testing activities. The cultural resources recorded during the survey document the presence of human groups in the reservoir beginning in late Paleo-Indian times and extending to the present. Based upon the limited occurrence of diagnostic artifacts, most of the prehistoric occupation occurred during the Archaic. Historic sites recorded were occupied primarily during the last quarter of the 19th century and the first quarter of the 20th century.

This report documents the research design and particularly the methodology utilized during the project. Special emphasis is given to describing the systematic and intensive survey, as well as to the random/judgmental approach of selecting the various sites for limited testing. Cultural material recovered during testing activities are described in techno-morphological terms.

The nature of. survey projects in general and the paucity of reliable time markers recovered during field work severely limited the development of a cultural chronology for the study area. Research efforts resulted in the development of a model of 1 ithic technology based on the ready availability of raw materials. Also presented is a settlement and subsistence pattern model which is based primarily on a rainy and dry season dichotomy and the availability of food resources. 

TABLE OF CONTENTS

Page

ABSTRACT ...........................

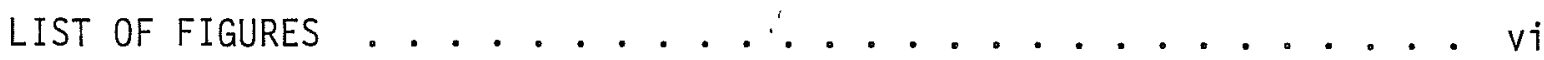

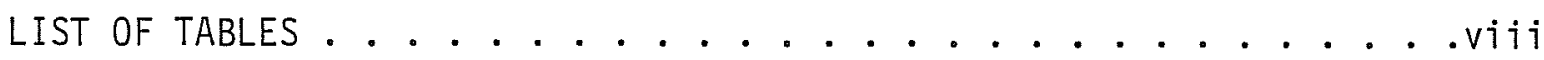

ACKNOWLEDGMENTS ..................... . . .

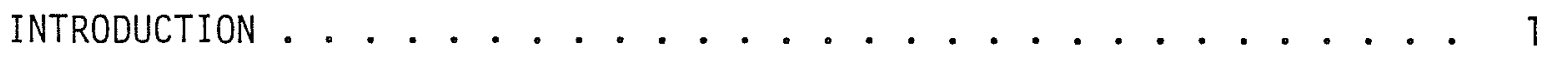

The Proposed Project . . . . . . . . . . . . 1

Changes in the Project .............. 2

Effects of Changes ................ 2

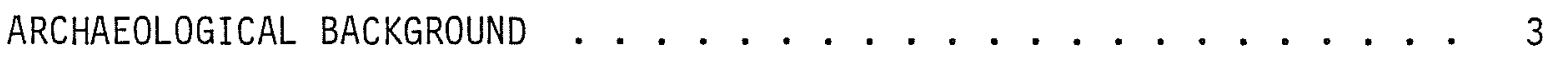

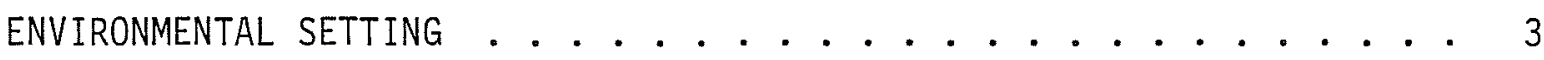

Physiography ................. 3

Geology .................... 5

Topographic Setting............... 6

Climate and Weather and Its Effects on Human Behavior..... 7

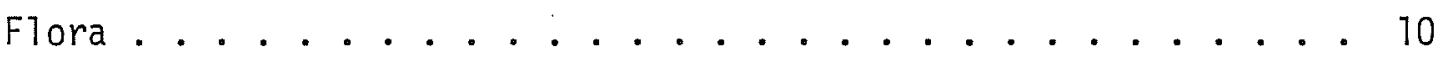

Fauna ...................... . 11

THE FIELD PROJECT . . . . . . . . . . . . . . . 14

The Intensive Survey . . . . . . . . . . . . 15

Supplementary Investigations . . . . . . . . . 28

Procedures Used in Selecting Sites

for Supplementary Investigations . . . . . . . . . 31

RESULTS OF THE PROJECT ......................... 39

Field and Laboratory Analysis . . . . . . . . . . . 39

Lithic Materials ................ . . 66

Chipped Stone .............. 66 
Page

Ground Stone . . . . . . . . . . . 116

Hammerstones ................... 178

Heat-Fractured Rock ............. 119

Other Lithic Materials . . . . . . . . . . 121

Other Materials ................... 122

Historic Artifacts . . . . . . . . . . . . 126

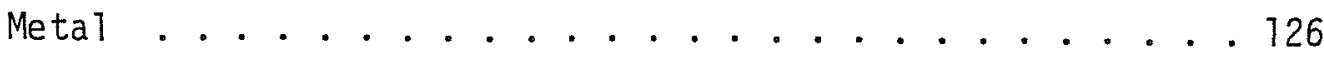

Ceramic ................... 129

Porcelain .................. 132

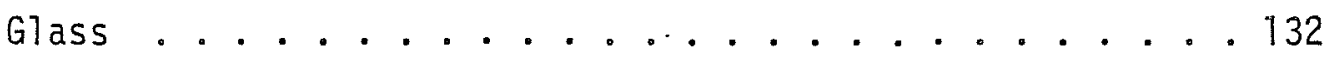

Miscellaneous Historic Items . . . . . . . . . 137

Descriptions of Representative Sites ........... 138

41 LK 31 and 41 LK 32 . . . . . . . . . . . . . . . . . . . .

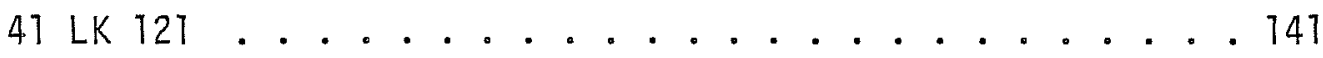

41 LK 152 . . . . . . . . . . . . . 144

41 LK 159 . . . . . . . . . . . . . . 149

41 LK 171 . . . . . . . . . . . . . . 155

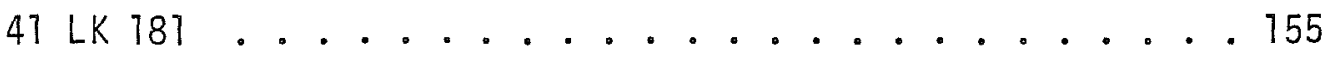

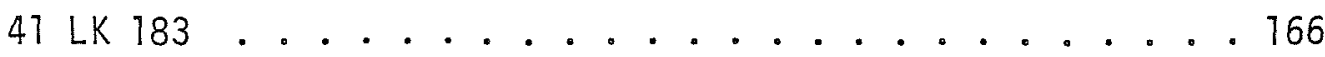

41 MC $199 \ldots \ldots . \ldots 169$

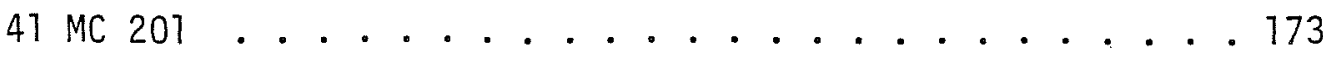

47 MC $209 \ldots \ldots 187$

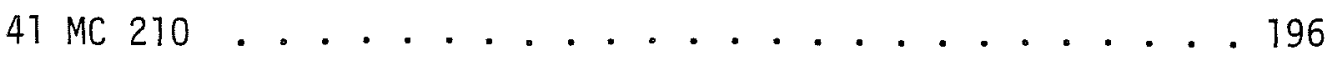

41 MC $214 \ldots \ldots . \ldots 198$

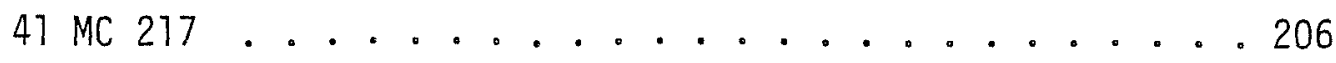

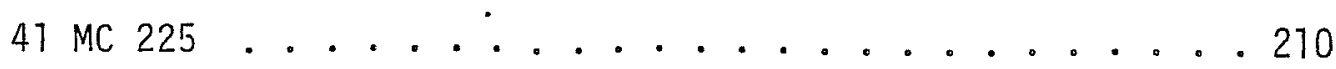


Cultural Resources of the Study Area . . . . . . . . 213 Low Density Scatters . . . . . . . . . 213

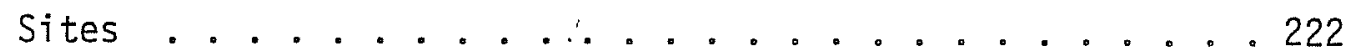
INTERPRETATIONS . . . . . . . . . . 225

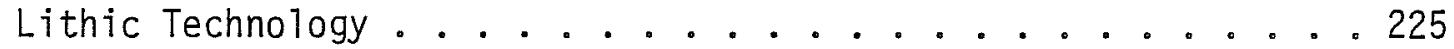

Settlement and Subsistence ............. 240

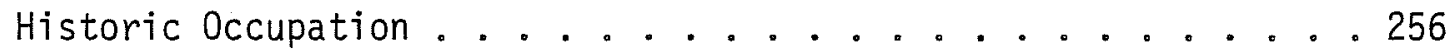

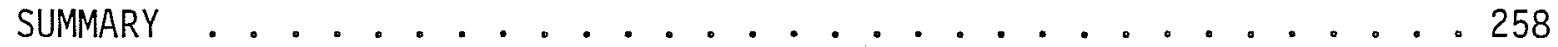
PROVISIONAL RECOMMENDATIONS . . . . . . . . . 260

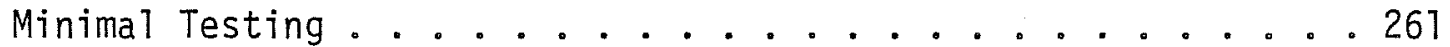

Limited Testing . . . . . . . . . . . . . 262

Intensive Testing . . . . . . . . . . . 262

No Additional Investigations . . . . . . . . . 263

Research Orientation of Future Investigations . . . . . 263 REFERENCES CITED . . . . . . . . . . . 264 KEY TO TABLES $14,15,16$, AND 17 , FLAKES AND CHIPS $\ldots \ldots 277$

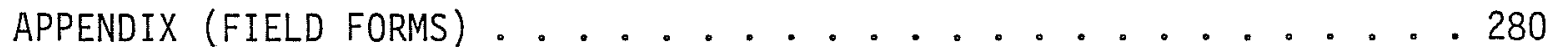




\section{LIST OF FIGURES}

Page

1. Nueces River Project, Choke Canyon Reservoir, CRI Survey Areas

2. Subdivisions of Water Courses................ 8

3. Map of W. W. Walton Property . . . . . . . . . . . 19

4. Map of N.H. Schwartz, R. T. McDermott, and

J. Davidson Properties ................. 20

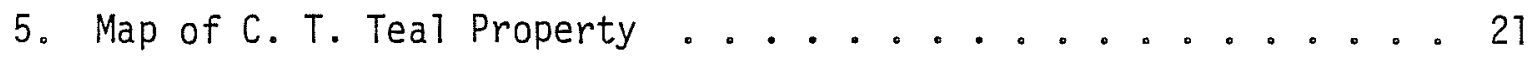

6. Map of G. Morri11 Property ............... 22

7. Grouping the Sites by Topographic Setting and Elevation . . . . 37

8. Lithic Artifacts: Cores, Trimmed Cobbles,

Flakes, and Chips................. 69

9. Lithic Artifacts: Unifaces and Bifaces ........... 81

10. Lithic Artifacts: Various Bifaces and Ground Stone . . . . . . 95

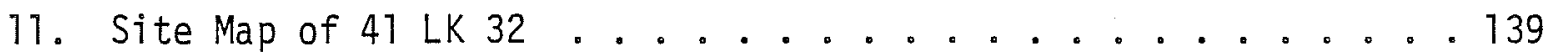

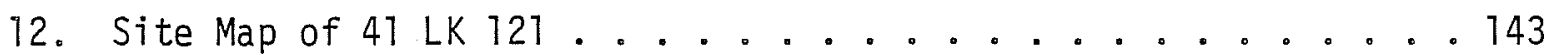

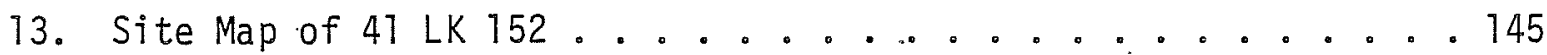

14. Views of 41 LK 152, 41 LK 159, and 41 LK 181 . . . . . . . . 148

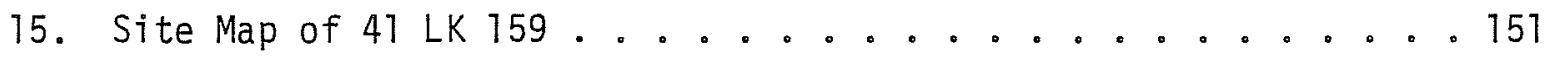

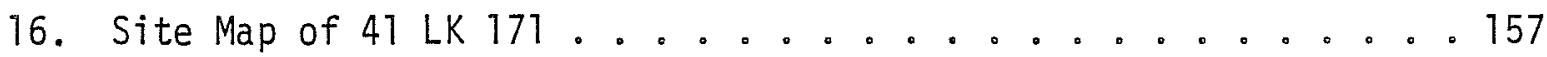

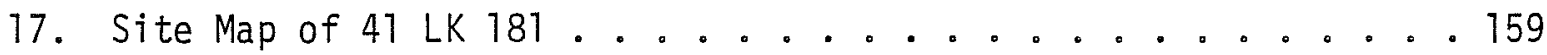

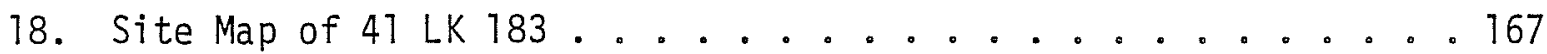

19. Site Map of 41 MC 199 .......................... 171

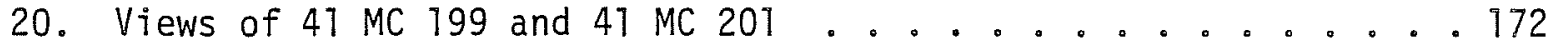

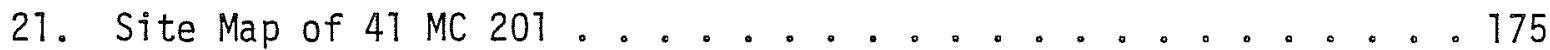

22. Views of 41 MC 201, 41 MC 209, 41 MC 214, and 41 MC 225 .... 185

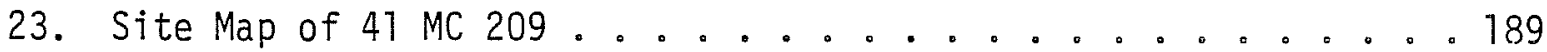




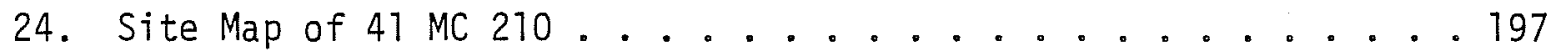

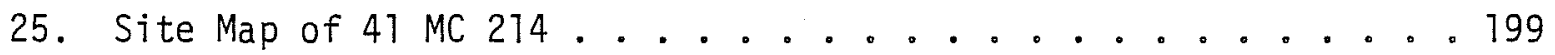

26. Site Map of 41 MC 217 . .......................... 207

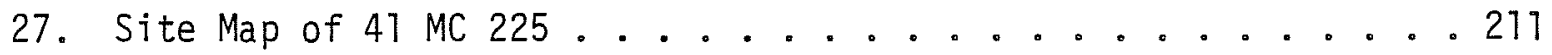




\section{LIST OF TABLES}

Page

1. Surveys Compared .................... 23

2. Site Variables ................ 32

3. Sites in Each Group ...................... 38

4. Characteristics of Al1 Recorded Sites............ 40

5. Cultural Materials at A11 Recorded Sites .......... 49

6. Low Density Artifact Scatters (LDS) . . . . . . . . . . . 58

7. General Classification of Collected Aboriginal Materials . . . 64

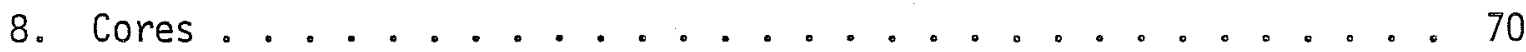

9. Trimmed Artifacts ................... 73

10. Unifacial Artifacts .................... 82

11. Thick Bifaces.................... . . 85

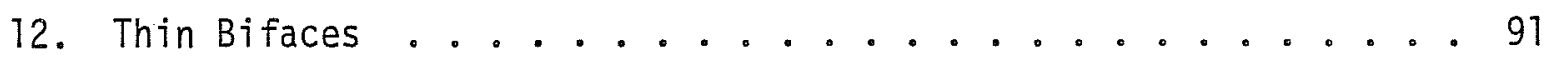

13. Projectile Pointlike and Miscellaneous Bifaces ........ 99

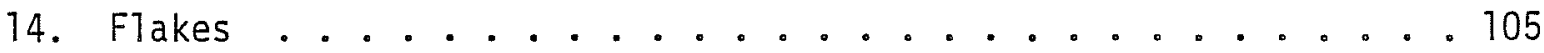

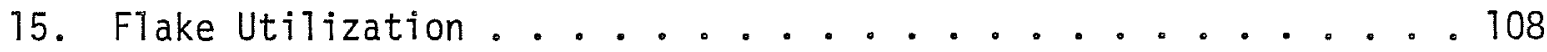

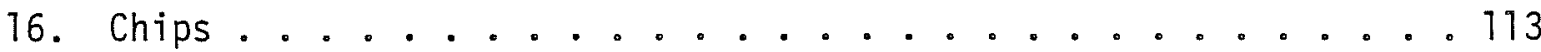

17. Chip Utilization ................... 114

18. Lithic Shatter, Split Cobbles, Hammerstones . . . . . . . 115

19. Ground Stone ..................... . 117

20. Heat-Fractured Rock ................. 120

21. Mussel and Gastropod She11 . . . . . . . . . . . 124

22. Occurrence of Characteristics at A11 (113) Recorded Sites . . . 214

23. Attribute Analysis of Sites ................ 217

24. Topographic Settings of Site Types . . . . . . . . . . 218 viii 
25. Diagnostic for Testing Models . . . . . . . . . 228

26. Evidence for Lithic Reduction Activities at Recorded Sites, by Location ... . . . . . . . . . . . . 231

27. Food Processing and/or Consumption by Lithic Reduction Phases and Location, Recorded Sites . . . . . . . . . . 232

28. Summary of Lithic Reduction Phases with Food Processing and/or Consumption, Recorded Sites ............. . 233

29. Evidence for Lithic Reduction Activities at Tested Sites, by Location . . . . . . . . . . . . . . . 234

30. Food Processing and/or Food Consumption by Lithic Reduction Phases and Location, Tested Sites . . . . . . . . . 235

31. Summary of Lithic Reduction Phases with Food Processing and/or Consumption, Tested Sites ............. 236

32. Evidence of Core-Tool and Core-Flake Industries at Recorded Sites ................ . . 238

33. Evidence of Core-Tool and Core-Flake Industries at Tested Sites................. . . 239

34. Generalized Topographic Settings of Site Types A-V . . . . . 244

35. Generalized Topographic Settings of Single Site Attributes . . . 245

36. Comparison of Sites $1 \mathrm{~km}$ or Less from Permanent Water and Sites More than $1 \mathrm{~km}$ from Permanent Water . . . . . . . . 247

37. Relationships Among Food Processing and/or Consumption Activities . . . . . . . . . . 248

38. Major Categories of Prehistoric Sites $(W-Z) \ldots 250$

39. Percentages of Stone Tool Types at Tested Sites . . . . . . . 251

40. Percentages of Flake and Chip Types; Presence of Mussel and Gastropod She11 and Heat-Fractured Rock at Tested Sites . . . . 252

41. Time Indicators in Collected Materials . . . . . . . . . 254

42. Time Indicators in Survey Data (not collected) . . . . . 255

43. General Categories for Historic Sites . . . . . . . . . 257 


\section{ACKNOWLEDGMENTS}

Studies of past human behavior are seldom accomplished without substantial contributions from many individuals and organizations. The authors wish to formally acknowledge the support provided by those who have helped in the completion of this study. The residents of Three Rivers, Calliham, and Tilden welcomed and assisted the field crew of the Cultural Resources Institute at every opportunity. We are especially indebted to Buford Dugger, Joe Crawford, David Thoms, and their families, for they made our stay in Three Rivers most enjoyable.

This study was carried out as a subcontract with the Center for Archaeological Research (CAR) at The University of Texas at San Antonio (UTSA). Dr. Thomas R. Hester, Director of CAR and Principal Investigator of the entire project, maintained order in this joint venture and cooperated with CRI personnel in every possible manner. We also extend a special thanks to Grant D. Hall, Field Director for the overall project, Dr. Joel Gunn, Daniel E. Fox, Royce Mahula, David Brown, and all of the CAR field crew. Each person contributed his time and knowledge as well as direct assistance during the project. Discussions with these people provided us not only with a significant learning experience, but also with valuable insight in past human behavior in the Choke Canyon Reservoir area.

Thoms and Montgomery carried out most of the testing phase of the survey project. However, time limitations were imposed and without the assistance of several volunteers during field work we would not have been able to complete the reported testing. We extend our gratitude to Bill Shumann, Larry Henson, David Brown, Don Rael, Philip A. Bandy, and Walter Thoms, each of whom contributed several days to our field effort. Walter Thoms. (Alston's father) was especially helpful because of his knowledge of the area and acquaintance with local residents.

We also wish to express our gratitude to the Texas Historical Commission, especially Alton Briggs; to the Bureau of Reclamation, especially Stephen Ireland, Bob Rowel1, and Rudy 0Iivo; and to Joe Coughran of the U.S. Soil Conservation Service at Tilden. These people and their organizations freely extended valuable information and services, cooperating with us throughout the study. Without their assistance, the successful completion of this project would not have been possible.

People in other departments at Texas Tech University made substantial contributions to the project. Dr. Henry Wright of the Range and Wildlife Department arranged for us to use their FM transceivers during the survey; this was of great help. Dr. Stuart Pimm of the Biology Department helped us with the computer programming. Dr. B. L. Allen of the Plant and Soil Science Department did the soil analyses. We also appreciate the use of the cartography equipment in the Geography Department and the drafting equipment in the Civit Engineering Department.

Many people associated with the Cultural Resources Institute also contributed to this study. We extend a special word of thanks to Dr. William J. MayerOakes, Director of CRI and of the CRI portion of the Nueces River Project. He provided the authors and others associated with the project with guidance 
and insured that all phases of our study were completed and met his high standards of scholarship. Alice Portnoy acted as project manager and editor. Richard Alvey and Christopher Jurgens assisted Thoms and Montgomery throughout the survey phase of the project. They also washed all the artifacts and completed the initial cataloging and classification procedures. In addition, Alvey prepared draft copies of the site maps and defined the vegetational associations within the study area. The final versions of the drafted illustrations were prepared primarily by Brook Bowman with assistance from Steve and Toni Ireland. Many of the primary data tables were organized and proofed by Janie Randolph, Roanne Vidal, and Linda Thoms, who also assisted in preparing the final version of the property maps. Typing of the various drafts of this report was done by Linda Austin, Janie Randolph, Roanne Vidal, and Elaine Reimer.

Most of the original draft report was written by Thoms and Montgomery, but Alvey prepared the sections mentioned above; Portnoy wrote introductory material for several sections and added transitional material in some sections. Montgomery and Thoms jointly prepared the draft chapter on cultural materials. Montgomery wrote the draft sections on. geology, physiography, climate, and site-testing methodology. Thoms prepared the draft sections on site descriptions, survey strategy and data, settlement and subsistence, cultural history and recommendations. Portnoy later extended Thoms's and Montgomery's work and revised the original draft report.

Thoms and Montgomery also extend sincere appreciation and special thanks to their wives, Linda Thoms and Cori Montgomery, who endured their prolonged absence and provided encouragement throughout this project. 

INTRODUCTION

This report of the survey and limited (surface and subsurface) testing of previously unrecorded sites is one part of a three-part subcontract between Texas Tech University (TTU) and The University of Texas at San Antonio (UTSA). The subcontract project was carried out between Ju1y 1, 1977 and September 1, 1978 by TTU's Cultural Resources Institute' (CRI). As are the other two parts of the project (historical research and historic sites archaeology), this part is based on the Scope of Work requirements of the Bureau of Reclamation RFP \#50-V0897 and the subsequent proposal and research design submitted to UTSA by CRI (Mayer-Oakes 1977).

\section{The Proposed Project}

The Scope of Work for the Nueces River Project (Choke Canyon Reservoir) required that research be directed toward the following objectives:

1. Establishment of a sound cultural chronological framework for the project area;

2. Examination of settlement and subsistence patterns evident in the project area;

3. Preparation of nomination forms for each site or district considered eligible for inclusion in the National Register of Historic Places;

4. Recommendations for Phase II mitigation.

In addition to the required topics, several other topics were proposed by CRI. They were considered supplemental and had as their objective the provision of more specific data useful in interpreting past human behavior. They were as follows:

1. Study of natural resources available to prehistoric inhabitants of the project area;

2. Study of lithic technology with emphasis on tool types and functions;

3. Study of seasonality and scheduling practices;

4. Development of a predictive model based on ethnohistorical and archaeological data stressing human behavior with emphasis on settlement and subsistence patterns. 
Changes in the Project

The original proposal submitted by CRI contained an elaborate research design that was both monetarily and temporally expensive. It was submitted to the Center for Archaeological Research (CAR) of UTSA, the prime contractor, as a statement of what could be done, assuming that the requested funds were available from the Bureau of Reclamation. After reviewing the proposal and gaining additional knowledge about available funds, CAR reduced the funds allotted to the TTU survey/testing project by approximately $50 \%$. The proposai for the entire Choke Canyon project was then submitted to the Bureau of Reclamation. The Bureau then found it necessary to reduce funding for the survey/testing project by approximately $10 \%$. There was not sufficient time to develop a new research design each time there was a reduction in funding. Rather, we took the position that we would strive to attain as many and as much of each of the original objectives as was permitted by available time and money.

\section{Effects of Changes}

These changes affected costs, personnel, and field techniques; directly related were various effects on the accomplishment of project objectives.

First of a11, we had less time to prepare for field work, but we could compensate for this because both Montgomery and Thoms had previous experience in the south Texas area.

As a result of the reduction in our project time, the anticipated complementary data from CAR were processed at a time when we were already preparing our report. This had an effect on the objectives of determining seasonality and scheduling practices as well as elucidating cultural history. The CRI project did not recover a significant number of soil samples or faunal remains, and only one site yielded sufficient charcoal for dating purposes. While the CAR project did recover the above types of materials, they were not analyzed in time for incorporation into the CRI study. Because only a limited amount of cultural material was recovered (from $10 \%$ of the sites recorded by CRI), there were not enough materials for a detailed study of site function. This also prevented us from making detailed site-by-site recommendations for Phase II (testing phase) and National Register nominations.

Increasing the transect width resulted in a reduction in the intensity of the survey. The decrease in survey intensity obviously affected the number of sites recorded in relation to the target universe ("a11 potentially observable cultural resources," Thoms 1978:3). This has been demonstrated by CAR's discovery of previously unrecorded sites in an area surveyed by CRI (Grant D. Ha11, May 15, 1978, personal communication). With fewer of the observable sites recorded than anticipated, the Choke Canyon survey data are less complete as they reflect the target universe. Therefore, there is a greater possibility that potentially significant sites remain undiscovered. We feel, however, that the vast majority of observable cultural resources were recorded and that our survey techniques allowed us to record numerous examples of all types of sites. The fact that some sites remain unirecorded, of course, affects the settlement pattern study, but again we feel that the negative effect is minimal. Our Choke Canyon survey data are most amenable to a study of the area's settlement patterns. 
Data gathered regarding natural resources were not significantly affected by the survey being less intensive. The primary difficulty in studying natural resources in the Choke Canyon area rests on the fact that only a smal1 percentage of the area retains native vegetation. Most of the area has been mechanically cleared and the present vegetation is more a result of clearing activities than of natural processes. During the Historic period, other factors such as overgrazing and droughts have altered the vegetational pattern resulting in a denser brush cover.

The various changes in our overall survey strategy affected the results of the work at Choke Canyon. We were able to accomplish less than anticipated primarily because fewer cultural materials were collected during the project. As a result, we concentrated on utilizing our most reliable data, site location. These data have been found to be useful in developing a general settlement pattern model which includes some seasonality and site function information.

\section{ARCHAEOLOGICAL BACKGROUND}

This report of the work done by CRI-TTU under subcontract to CAR for the Bureau of Reclamation is one part of a many-part-project. Duplication of both effort and report material is being avoided. A comprehensive treatment of the archaeological background and regional prehistory will be found in Volume 5 (Hall, Black, and Graves 1981) of the Choke Canyon research series. The reader is also referred to the report of the initial archaeological survey of Choke Canyon carried out by personnel from the Texas Historical Commission (THC) (Lynn, Fox, and O'Ma11ey 1977:38-42) and to Montgomery (1978:15-23).

A 7 imited archaeological reconnaissance of the Choke Canyon Reservoir area was carried out in 1968. Eighteen sites were recorded during this survey, and it was clearly demonstrated that the area contained substantial and potentially significant prehistoric and historic cultural resources (Wakefield 1968). In 1974 and 1976, the major portion of the Choke Canyon Reservoir area was subjected to a cultural resource survey which resulted in the discovery of 161 prehistoric and 11 historic sites (Lynn, Fox, and O'Malley 1977). Due to difficulties in obtaining access to certain privately owned areas within the reservoir area, approximately 3239 hectares remained unsurveyed in 1977. The survey conducted by CRI was originally intended to complete the coverage of the remaining areas. However, the problem of land access was not completely solved, and only 2544 hectares were accessible to CRI. As of the end of 1978, approximately 695 hectares within the reservoir area remained to be surveyed.

\section{ENVIRONMENTAL SETTING}

\section{Physiography}

The Choke Canyon Reservoir (Fig. 1) is located within the area of southern Texas which is part of a natural region termed by some as the Rio Grande Plain (cf. Inglis 1964; Hester, Gilbow, and Albee 1973; Montgomery 1978). Texas boundaries for this region are the Rio Grande on the west and south, the Gulf of Mexico on the east, and the Balcones Escarpment of the Edwards 


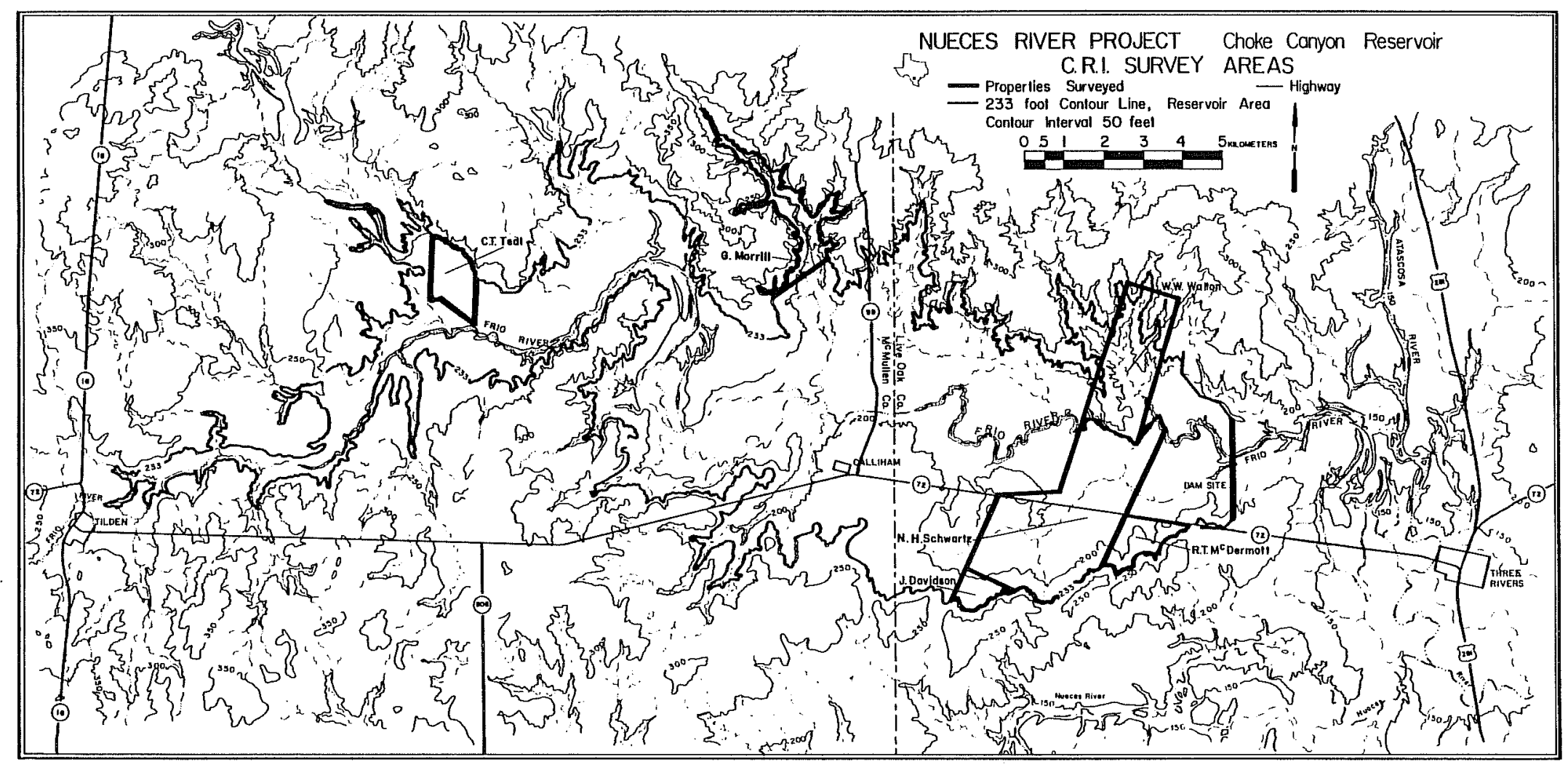

Figure 1. Nueces River Project, Choke Canyon Reservoir, CRI Survey Area. 
Plateau on the north (cf. Montgomery 1978:3). Given these boundaries, the Rio Grande Plain encompasses most of the southern Texas region between San Antonio and Brownsville, Texas. Approximately 26,350 square miles are included within this region (Chambers 1946:111).

Given the boundaries described above, the Rio Grande Plain lies within the physiographic unit termed the West Coastal Plain by Fenneman (1938) and Thornbury (1965). Other physiographic terms for this area include the Coastal Plain (Hunt 1967) and the South Texas Plains (Johnson 1931).

The Rio Grande Plain exhibits a varied topography. At the base of the Edwards Plateau, the region reaches its maximum elevation of 1000 to 1100 feet above mean sea level (Chambers 1946:112). The elevation of the Rio Grande Plain gradually decreases as one moves east towards the Gulf of Mexico. The central portion and most of the northern portion of the area are rolling plains, while the southeastern portion is a level section which generally parallels the Gulf of Mexico coastline. In contrast, the western and southwestern regions exhibit a rugged or dissected topography due to the action of short, rapid streams flowing into the Rio Grande (ibid.).

Geology

Previous studies within the reservoir area (e.g., U.S. Department of the Interior 1975; Lynn, Fox, and O'Ma1.ley 1977) have described the geological characteristics of the study area. The reservoir area is underlain by Tertiary strata formed by sedimentary processes. The Frio River has cut into three geological formations during its history. The deepest of these is the Jackson Group which is overlain by the Frio Formation. The uppermost geological formation is named the Catahoula.

A11 of these sedimentary formations were laid down during the Cenozoic era, an interval of time marked by numerous marine transgressions and recessions over parts of present-day Texas (Plummer 1966:526-529). The earliest Fayette Formation is a widespread Eocene marine deposit laid down during extensive sea advancement, while the later Frio and Catahoula Formations are primarily 01 igocene land deposits which indicate sea regression. Each formation retains specific lithologic characteristics which are related to the cyclical Cenozoic sea movements.

Plummer (1966:678) provides the following 1ithologic description of the Jackson Group:

It consists of shallow-water, marine, and beach deposits, composed of medium and fine-grained, thin-bedded sand, argillaceous and tuffaceous clays and tuffs, and lentils of coarse, rounded, and polished sand grains. In many places the beds are somewhat fossiliferous. They represent the lower, or Eocene, portion of the pyroclastic epoch, during which violently active volcanoes began to play an important part in supplying material to the sediments. 
In the western area of the Choke Canyon Reservoir area, the sandstone layers capping the Jackson Group have formed topographic features referred to as bluffs or cuestas (Lynn, Fox, and 0'Malley 1977:6). The top of the Whitsett member of the Fayette Formation is overlain by the Frio and Catahoula Formations.

The Frio Formation is characterized by the presence of massive, greenish gray clay. As a whole, this formation consists of "over $95 \%$ clay, about $4 \%$ sand and sandy silt, and concentrations . . . The silt is gray, extremely fine grained, noncalcareous, and very gypsiferous" (Plummer 1966:706). Lithologically, the Frio Formation represents nonmarine depositions, which contrasts with the earlier Jackson Group.

Unconformably overlying the Frio Formation is the Catahoula Formation. The formation is primarily a tuff bed which ranges in color from white to greenish gray. The tuff is "finely textured, massively bedded, . . and are interbedded with tuffaceous clay and tuffaceous sand" (ibid.:721). In 1ithological terms, the Catahoula consists of about $60 \%$ pyroclastic materials (tuff), 20-30\% sandstone, $10-20 \%$ argillaceous clay, and a trace of conglomerate. The tuff component of the Catahoula Formation has "at least six types of soils" (Plummer 1966:721).

Outcrops of all three of the formations described above can be related to general physiographic features within the region of the Choke Canyon Reservoir. Plummer (1966:681) has noted that the Jackson Group outcrops are characterized by an undulating topography with moderate slopes, generally wide valleys, and ranges of low hills. Most of these surfaces are lightly vegetated.

The next formation, the Frio, is surficially expressed as a generally flat, featureless plain covered by mesquite, various cacti and thorny brush. This plain has been termed the Frio Plain, and it extends from the southeast corner of Atascosa County southeastward across McMullen County to Rio Grande City. The width of this plain varies, with the narrowest areas located in Live Oak $(1.6 \mathrm{~km})$ and McMullen $(3.2-6.4 \mathrm{~km})$ Counties.

Catahoula outcrops in south Texas occupy "a belt of rolling, moderately dissected, more or less improved and cultivated farmland in south-central Texas and pasture land in south Texas which extends from southern Gonzales County, through northern Karnes, northern Live Oak, and northwestern Duval Counties, to eastern Webb County, then bends southward across eastern Webb County and disappears beneath younger formations in Zapata County." Width of this outcrop area is widest in McMullen (12.8-16.0 km) and Duval Counties (Plummer 1966:713-714). Jett $(1977: 6)$ reports that this formation forms the narrow "choke" area of Choke Canyon at the proposed damsite on the Frio River.

\section{Topographic Setting}

Topographic setting is defined in this report either in terms of water courses or is given an upland designation. River is used to describe the Frio River, and primary tributary refers to major water courses which empty into the river. A11 primary tributaries are named on the USGS $7.5^{\prime}$ topographic maps. These are San Miguel Creek, Opossum Creek, and Willow Hollow, all of which empty into 
the Frio River from the north. Secondary tributary defines water courses which have confluences with primary tributaries. The term minor tributary refers to sma11 drainages which empty into secondary tributaries, as well as to smal1 unnamed water courses which flow directly into the river. Most of the minor tributaries which empty into the Frio are located south of the river on the N. H. Schwartz, J. Davidson, and R. T. McDermott properties. Each of the above water courses is subdivided into three parts: the floodplain, the terrace(s), and the valley wall. We use the term upland to describe areas above and not directly associated with a specific water course. These terms are slightly modified from those used by Lynn, Fox, and 0'Malley (1977) to describe the Choke Canyon topography. Figure 2 illustrates our usage of terms which subdivide water courses.

\section{Climate and Weather and Its Effects on Human Behavior}

The Rio Grande Plain has a generally mild climate, due primarily to the area's proximity to the Gulf of Mexico. The Gulf of Mexico, which retains a stable water temperature, provides a moderate (in terms of temperature) source of air flow over the Rio Grande Plain. By being the most southward region of Texas as well as having the protection of the Edwards Plateau to the north, the Rio Grande Plain is generally spared severe winter weather (cf. Chambers 1946:112).

Mild winters and long growing seasons are usual within the Rio Grande Plain. When colder conditions do occur, they are short lived and the temperature rarely drops below freezing. Thornthwaite (1948) has described the contemporary climate as being semiarid and megathermal. The Choke Canyon Reservoir region has also been described as an area exhibiting a mesothermal steppe climate with the dry season occurring in the winter months (Russel 1945).

Tilden, Texas is a contemporary town located at the west end of the proposed reservoir area. Yearly climatological information from the U.S. Department of Commerce Tilden Station (No. 20-41) has been summarized by Lynn, Fox, and 0'Malley (1977:7). They report that the yearly precipitation figures for Tilden average 23.08 inches $(60 \mathrm{~cm})$, with most precipitation occurring during thunderstorms and heavy downpours. Evaporation exceeds precipitation by about 36 inches $(91.44 \mathrm{~cm})$ annual1y, which leads to the mesothermal and megathermal designations given above by Russel (1945) and Thornthwaite (1948). Southeasterly winds prevail in the area, and occasional hurricanes affect the climatological picture, sometimes in an extreme fashion. Drought conditions are common and also extreme in some cases (Lynn, Fox, and 0'Malley 1977:7). Water flow measurements along stations on the Frio River and nearby streams reflect the highly seasonal precipitation cycle.

The Choke Canyon area is typified by a semiarid and megathermal climate (Blair 1950:102). According to Blair, there is a 20-40\% deficiency of moisture for plant growth, with plant growth occurring throughout the year. Most of the rain falls in the late and early fall; this corresponds to the period of highest river flows.

Rainfall data at Three Rivers and George West in the Choke Canyon area and at Pearsal1 and Uvalde upstream on the Frio River were collected. The rainfall 


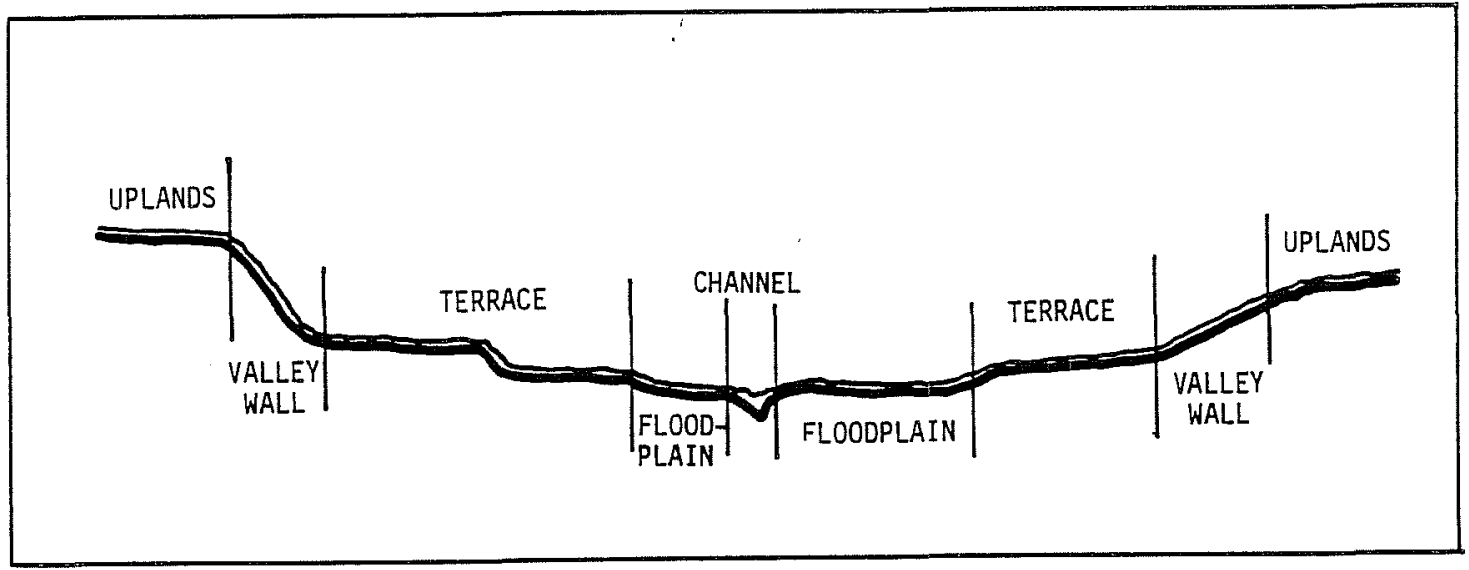

a

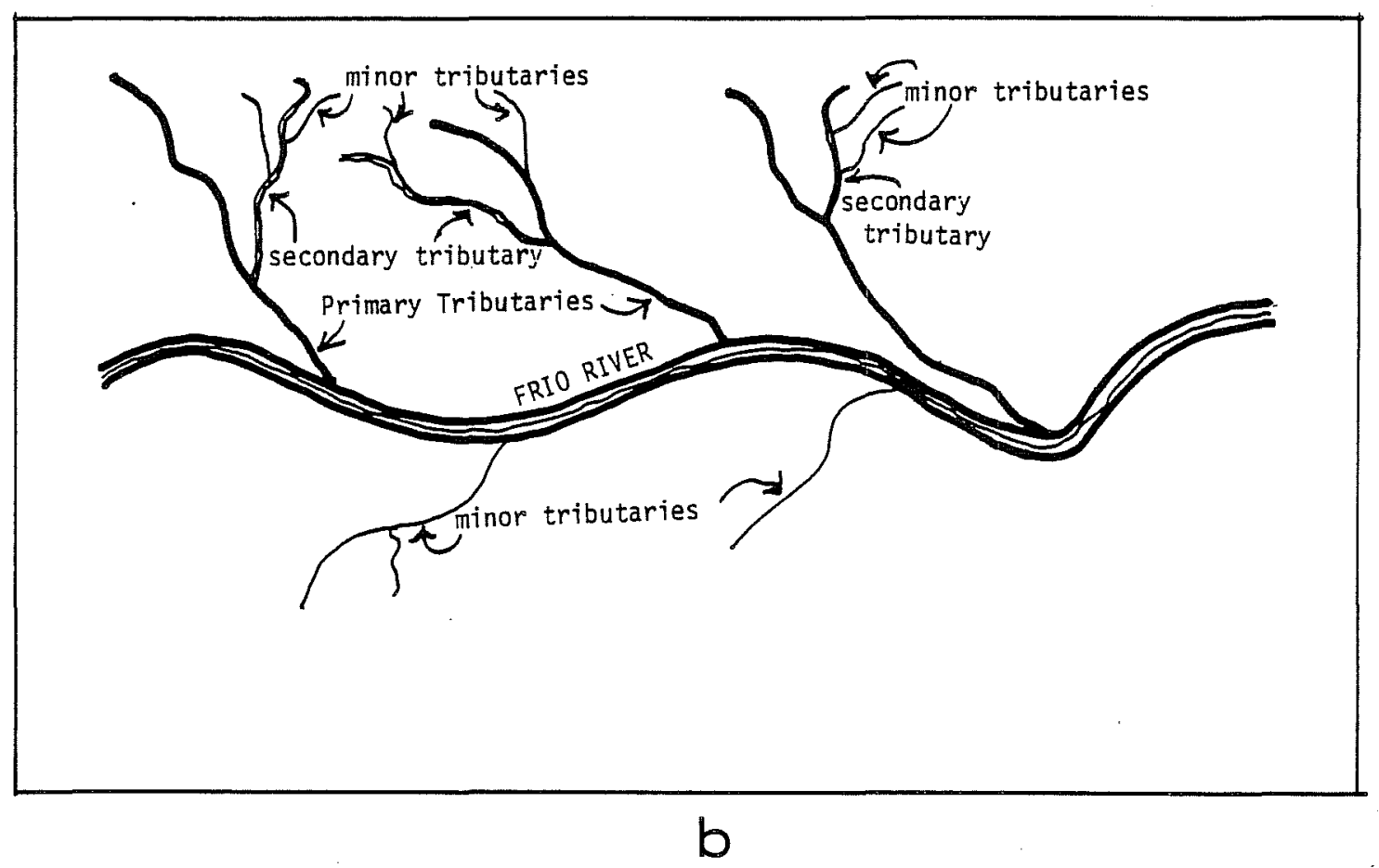

Figure 2. Subdivision of water Courses. a, schematic section; b, plan. 
upstream peaks in May and June, contributing more water to the rivers during these months than in the fall. There is a low in July, with a rise in the early fall months of September and October (hurricane season). Localized heavy rains may fall at any time during the summer, leading to flood situations. A good example of this is the 21.01 inches of rain which fell in July of 1932 at Uvalde (U.S. Department of Commerce, Weather Bureau 1952:101). Results of that rain were felt al1 the way down the Frio River to Three Rivers. On July 8, 1932 at Calliham, Texas, the U.S. Geological Survey (U.S. Department of Interior, Geological Survey 1950:286) river gauging station recorded a stage height (crest) of 39.20 feet above datum. The datum at that point is 153.47 feet above mean sea level (msl). At that point, an area over $5 \mathrm{~km}$ wide would be submerged by a crest of that height. At Three Rivers, the gauge height was 43.8 feet above datum, datum lying at 101.13 feet above ms 1 (ibid.:228). Flood stage at this station is 37 feet above datum (Bunnemeyer $1921: 149-151)$.

Maximum stage height at Three Rivers occurred during Hurricane Beulah in September 1967 (U.S. Department of Interior, Geological Survey 1967:472) with a measurement of 49.21 feet above datum. This would inundate everything below the 150 feet above msl elevation. When plotted on the USGS $7.5^{\prime}$ topographic map, most of Three Rivers was inundated. This agrees with flood marks and comments by local residents (David Thoms, May 1978, personal communication). Three Rivers received 21.02 inches of rain during the month of September 1967 (Trowbridge 1967:420). An area $5 \mathrm{~km}$ wide was under water during this flood.

During the same storm, Tilden had 12 inches of rain. The Frio River crested at 28.92 feet above datum (218.1 feet above ms 1), inundating everything below. 247.02 feet above ms 1. Approximately one-half of Tilden was submerged during this flood (Joe Coughran, May 1978, personal communication). Plotting this elevation (247.02 feet) on the USGS $7.5^{\prime}$ topographic map, an area of bottomland $1 \mathrm{~km}$ wide would be inundated.

Hurricanes occur frequently enough that residents of the area have learned that they must be prepared to move to higher ground during hurricane season. Presumably if the Anglo-Americans who have only resided in the area since 1858 (first occupation of Yarbrough Bend) have learned this lesson, a similar result should have occurred among the aborigines who previously occupied this area for a longer period of time.

To survive in this rather harsh environment, the native Indian peoples had to be tied into the natural cycle of events. If floods were known to occur during the late spring and early fal1--removing large sections of bottomland from use--the aboriginal populations would utilize other areas and resources during this time. Oviedo (1974:43) states that Indians killed large numbers of fish during the floods in April and May. Nets were probably used in sloughs out of the main flow. Other resources available on the upland, including game, would also have been utilized at this time. During August through October, prickly pear, mesquite beans, and deer also are available in the more open areas of the uplands. Pecans are available in November and December (James Templeton, November 1977, personal communication). Oviedo (ibid.:43-44) says that Indians utilizing the pecan groves on the lower Colorado scared off al1 the game and had nothing to eat but nuts. River flows for the month of November are low; 
river mussels (Unio sp.) could also be obtained at this time. From November to March, the aborigines would have been able to utilize the bottomlands. River flows during these months are the lowest of the year--below 150 cubic feet per second at Calliham (U.S. Department of Interior, Geological Survey: 1950, 1960, 1965, 1966, 1967, 1968, 1969, 1970, 1971, 1972, 1973, 1974, 1975, 1976).

As a hunting and gathering population, Choke Canyon's prehistoric inhabitants moved in a seasonal cycle to utilize resources in different areas. Other reasons may be attributed to these moves, e.g., river conditions and weather. People who are closely tied to their environment are aware of subtle changes in weather and river flows. They know what these mean and what appropriate actions must be taken.

\section{Flora*}

During the course of the survey it was noted that the vegetation of the area could be divided into associations, i.e., groups of plants that are usually associated with each other. One of the crew members, Rick A7vey, recorded and described these associations as follows:

Association 1 consists primarily of live oak, common hackberry, and water elm, with mesquite and whitebrush on its margins. Other plants are ball and Spanish mosses and mustang grapes. This association is mainly along the river bank.

Association 2 consists of common hackberry. along the creek edges but thins out toward the association's upstream edge. Large mesquite and whitebrush are common on the margins of the association. Margins are marked by the loss of the large common hackberry, while mesquites get smaller and whitebrush increases. There are occasional intruders such as Texas persimmon, spiny hackberry, prickly pear, agarita, and some acacia. There is a rare live oak in some areas. This association is normally clustered along the water courses and intermittent streams.

Association 3 consists of sparse to thick stands of Texas persimmon, agarita, spiny hackberry, prickly pear, soapbush, mesquite, and some yucca. Common hackberry may intrude on the downslope margin, rarely mescal-bean sophora and tasajillo. The upslope margin is usually marked by increasing numbers of acacias and mimosas, but these species may be scattered throughout. This association is normally on the valley wall slopes.

Association 4 consists primarily of acacias and mimosas. These occur in moderate to extremely dense thickets. Some spiny hackberry is scattered throughout. This association is normally found on very rocky ridge tops along the top of the valley wall.

Association 5 is mainly a mixing of the species from Associations 3 and 4 with many open areas. Plants include large mesquite, clumps of acacias, spiny hackberry, soapbush, agarita, prickly pear, yuccas, and an occasional Texas

*A historical study of floral and faunal changes in the region appears in an MA thesis by Christopher J. Jurgens (Department of Anthropology, Texas Tech University 1980). 
persimmon; a11 are interspersed with native grasses. This association is found mainly on flat upland areas.

Association 6 appears on previously cleared areas that were used for pastures and are not directly linked to any particular geographic zone. Species include Bermuda and other grasses and variable amounts of huisache, mesquite, whitebrush, and other intruders. The association is still used mainly as pasturage.

Association 7 was also cleared originally, but it is now densely overgrown with mesquite, prickly pear, soapbush, whitebrush, some acacias, spiny hackberry, some yuccas, and rarely mescal-bean sophora and spiny allthorn. This association covers most of the south side of the Frio River valley, except for the valley walls and the various stream courses.

Association 8 is that of fields currently under cultivation and is primarily cotton. This association is in the Frio River floodplain.

Association 9 is along an old dry slough bed of the Frio River. The species are mainly Drummond rattlebox and some low grasses and mesquites.

Alvey also noted desert willow growing along State Highway 72 , but not in any of the vegetational associations within the survey area.

Fauna

The Tamaulipan Biotic Province defined by Blair (1950:93-117) supports a large number of mammal species. Changes have occurred in this fauna since the 1500s, but it is still typified by predominantly arid-adapted species. Large animals which interfered with ranching activities in the late 1800s were eradicated. Buffalo (bison), pronghorn antelope, gray wolf, jaguar, and bear have all disappeared from the Choke Canyon area. Mountain lions and ocelots have become extremely rare in the area (J. C. Grubb, January 1978, personal communication). 01d World rats and mice (Family Muridae), nutria, and the armadillo have been introduced into the area in the last 150 years.

Fire was used in south Texas to drive game (Oviedo 1974:43). Among the coastal Indians, Oviedo (ibid.:44) states that during prickly pear season, when the Indians were perhaps near what is now Corpus Christi, they caught deer to eat. At other times of the year, they killed great quantities of "rats" along the rivers (Oviedo 1974:43).

In an analysis of faunal remains from sites in Zavala county, many varied species were identified (Hester and Hi11 1975:25-26). At the Tortuga Flat site (41 ZV 155), three bison, eight pronghorn, and 22 white-tailed deer were represented in the areas excavated. This reflects the relative proportions of animals utilized at this site; deer were more common at times than bison even in this northwest Rio Grande Plain site. Smaller lagomorphs and rodents appear to have made up a moderate portion of the aboriginal diet. Cotton rats (Sigmodon hispidus) are the most prevalent of the rodents, followed by woodrats (Neotoma micropus). Cottontail rabbits (Sylvilagus floridanus) are more prevalent than jackrabbits (Lepus californicus). Other rodents such as pocket gophers (Geomys 
sp.), white-footed mice (Peromyscus sp.), and ground squirrels (Citellus sp.) also occur and are good environmental indicators. Canids and procyonids are found as are mustelids, but no felids appear in the predator faunal record (ibid.). At $41 \mathrm{ZV} 60$ and $41 \mathrm{ZV} \mathrm{14,} \mathrm{the} \mathrm{faunal} \mathrm{record} \mathrm{is} \mathrm{approximately} \mathrm{the} \mathrm{same,}$ with the exception of a felid (Lynx rufus, bobcat) found at 41 ZV 14 (Hester and $\mathrm{HiT1}$ 1975:27-29).

Birds occur in the Choke Canyon area in great numbers. The Central Flyway funnels many migratory birds through the area (Peterson 1963:ix). The Choke Canyon area is on the edge of this flyway, lying $120 \mathrm{~km}$ inland from the coast (Eric Bolen, October 1977 personal communication). Many migrating waterfowl appear during their seasonal migrations in the spring and fall (ibid.:ix). Some winter in the area. A large number of geese and duck species are part of these migrations. In Coahuila, waterfowl were caught by Indian hunters swimming below the surface and drowning them by pulling them under (Ruecking 1953: 485). It is possible that south Texas aborigines used the same method. Twenty raptorial species occur in the area (Blair et al. 1968:309-320); the Texas Tech field crew observed five of these in Choke Canyon in 1977. Galliform birds are numerous in the Choke Canyon area.

The native wild turkey (Meleagris gallopavo) is present in the area. On Leoncitas Creek in 1844, Bollaert (Hollon and Butler 1956:370) noted many turkeys. Hester and Hil1 (1975:27) report turkey bone from $41 \mathrm{ZV} 60$ in Zavala County. The native Indians utilized this large bird; it provided quite a bit of meat and males have beautiful feathers (Blair et al. 1968:326).

Four species of ow1 occur in the Choke Canyon area (Peterson 1963:124-131). Feathers would be the only resource obtained from these birds. The archaeological implications of owls are that they deposit small mammal bones in refuse piles beneath their nests (Lundelius 1964:29).

Doves occur in great numbers in south Texas and while they are utilized heavily by modern sport hunters, they are hard to collect without a shotgun. Aborigines would have been able to collect some by means of bow and arrow, rocks, or snares.

Quail will allow humans to approach within range to use rocks or nets. They also cluster in coveys on the ground which would make capture with nets feasible. Traps constructed of basketry and netting would also work; modern wildlife biologists often use wire traps to capture quail for banding ( $P$. $B$. Uzze11, October 1978, personal communication).

Reptiles and amphibians were utilized by the local Indian population. Oviedo (1974:43) reported that the Indians ate snakes, lizards, frogs, and other kinds of reptiles. Bandelier (1972:62), in her translation of Álvar Nunez Cabeza de Vaca's diary, also reported that the aborigines ate lizards, salamanders, and serpents.

Blair (1950:104) reports 36 species of snakes and 19 species of 1izards occurring in the Tamaulipan Biotic Province. Four of the snakes are poisonous; three of these are the pit-vipers: copperhead (Agkistrodon contortrix), cottonmouth (Agkistrodon piscivorus), and western diamondback rattlesnake 
(Crotalus atrox). The eastern coral snake (Micrurus fulvius) also occurs in Choke Canyon. Other common snakes in the area are water snakes (Natrix sp.), corn and rat snakes (Elaphe sp.), king and milk snakes (Lampropeltis sp.), and the racer (Coluber constrictor).

Various turtles occur in different habitats in the reservoir area. Ten species of turties are 1isted for this part of Texas (B1air et al. 1968:216-229). Except for the Texas tortoise (Gopherus berlandieri) and the western box turtle (Terrapene ornata), al1 of them live in semiaquatic habitats. The softshell turtles (Trionyx sp.) and chelydrid turtles--snappers, etc.,--grow to large size and would provide a good food source.

One member of the Order Crocodilia occurs in the Choke Canyon area. The American a17igator (Alligator mississipiensis) occurs in and around the Frio River. The Karankawas along the coast (Newcomb 1961:66) utilized a11igator "grease" as mosquito repellant. Alligators can be caught in nets (K. C. Jurgens, January 1978, personal communication) or speared through the eyes as the Bidai did (Newcomb 1961:324).

Most lizards in the area are sma11 creatures, but members of the genus Sceloporus reach about 10 inches in length. Lizards are agile and hard to catch, but could be caught in large numbers around the edges of brush fires set by the Indians (Oviedo 1974:43; Bandelier 1972). Combined with vegetal food, this would result in a relatively balanced diet.

Amphibians (frogs and salamanders) occur mainly in moist areas along the creeks and rivers. The Urodela amphibians (salamanders) are either aquatic or semiaquatic in habitat preference (Blair et al. 1968:170-190). Five families of anurans live in the Choke Canyon area. Three of these families (Microhylidae, Pelobatidae, and Bufonidae) are toads. (We do not know whether oviedo considered toads as separate from frogs.) Most toads are more arid-adapted than frogs (W. Frank Blair, May 1976, personal communication). Two families of frogs (Hylidae and Ranidae) occur here. The hylid frogs are tree frogs; the ranids are "typical" frogs like the bullfrog (Rana catesbeiana) and leopard frog (Rana pipiens). Frogs can be caught by hand or speared.

Faunal analysis of material from late Prehistoric and Protohistoric sites in south Texas (Hester and Hil1 1975:25-29) yielded several reptile and amphibian species. Box turtle (Terrapene sp.), bul1snakes (Pituophis melanoleucus), rattlesnake (Crotalus sp.), rat snake (Elaphe sp.), racer snake (Coluber sp.), horned toad (Phrynosoma cornutum), box turtle (Terrapene ornata), slider turtle (Pseudemys sp.), and unidentified frog remains were identified (ibid.:28-29). The riparian zones are smaller in the Zavala County study area than in the Choke Canyon area; fewer aquatic or semiaquatic species might be found. More might occur in sites in the Choke Canyon area.

The Rio Grande Plain possesses a large and varied ichtyofauna (Hubbs 1957: 89-104; Hubbs 1976). Many of the species are smal1 fish, averaging less than four inches in length. Larger fish, such as gar, carp, catfish, sunfish, and drum, would have been obtainable by seining or bow fishing. Ruecking (1953:484-486) lists fish as a food eaten; they were caught with seines or shot with bows in historic times. 
Species such as alligator gar, carp, channel catfish, or flathead catfish will grow to large sizes. 01der flathead catfish may weigh $100 \mathrm{lb}$. Blue catfish can grow to 150 1b or more. Maximum weight for alligator gar is 300 lb (Blair et al. 1968:39-105). While modern Euro-Americans think of the gar as a "trash-fish," they can be eaten. Fish bone occurs at the Late Prehistoric Tortuga Flat site (41 ZV 155) in Zavala County (Hester and Hi11 1975:25). Alligator gar (Lepisosteus spatula) bone also occurs at 41 ZV 60 in Zavala County (ibid.:27). It has been reported that Indians of the region were using seines as a method of catching fish (Ruecking 1953:484-486). Cordage nets, depending on the mesh size, will operate as efficiently as modern nylon nets; large fish can be handled in this manner. Using smaller mesh size, seines can catch even minnows. Large numbers of these would provide as much food as fewer, large fish.

Of the modern ichthyofauna, many species reach their greatest densities in lakes. Large lakes were not a major habitat in this area in prehistoric times; therefore, lacustrine schooling fish such as shad were not as prevalent. Riverine fish such as gar, carp, various suckers, and catfish would have been prevalent. Prior to the erection of barriers downstream such as at Lake Corpus Christi, some marine species may have been able to move upstream in the Nueces drainage. In the Colorado River drainage, the Atlantic needlefish (Strongylura marina) has been caught as far upstream as Bastrop (Hubbs 1957: 95). This is over 120 river miles from the coast. Hubbs (ibid) suggests that coastal species such as sheepshead minnow (Cyprinodon variegatus), tidewater silverside (Menidia beryllina), and rainwater killifish (Lucania parva) may occur throughout the Tamaulipan Biotic Province.

What effects could changes in stream flow have on aquatic habitats? Price and Gunter (1943:143) state that small streams on the eastern flank of the Reynosa cuesta became intermittent in the period 1870-1895. A change to intermittent flow would el iminate most aquatic fauna in the feeder streams. This would reduce the amount of available food for an aboriginal hunting and gathering population.

\section{THE FIELD PROJECT}

The field project was conducted in two stages. The first stage, intensive survey, took place from August 1977 through September 30, 1977. The goal was to discover and record all cultural resources on the surface of the 2544-hectare (6285 acres) study area. We recorded 111 sites, 43 low density artifact scatters, and five isolated artifact finds. The second stage, supplementary investigation of a representative sample of the recorded resources, took place from October 14, 1977, through November 17, 1977. It consisted of various combinations of controlled surface recording and collection and test pit excavation at 15 sites. Two additional sites were recorded for a total of 113. Its goal was to collect data which could contribute to an understanding of natural resources, lithic technology, seasonality, and settlement and subsistence patterns in the area. 
The Intensive Survey

\section{Concept and Significance}

The survey of the 2544-hectare area in Choke Canyon Reservoir was designed as an intensive survey. Scovi11, Gordon, and Anderson (1972:3) broadly defined intensive survey as "a comprehensive and extended physical examination of an area, for the purpose of obtaining an accurate sample of data on all archaeological resources, situations, and associated environmental variables."

The term $100 \%$ survey is often used interchangeably with the term intensive survey. However, it is not practical and probably not possible to document the complete surface extension of the archaeological record in any given area during an intensive survey. The virtual impossibility of documenting al1 surface manifestations is sufficient reason to elect to use the term intensive survey as opposed to 100\% survey, which implies that al1 observable cultural resources are recorded.

The ideal goal of anthropological archaeology is to understand the whole of past human behavior. If this goal is to be achieved or even approached, the archaeologist must first know what data are available (i.e., he must define the archaeological record). During the intensive survey the archaeological record is in fact defined by discovering and reporting the nature and surface distribution of cultural resources.

The term target universe has been defined as "al1 potentially observable cultural resources within a specific study area" (Thoms 1978:3). Target universe is contrasted to the term "known universe, or those cultural resources which are actually documented as a result of an intensive survey in a specific study area." Therefore, the known universe is actually the data base for discussions relating to the target universe. Survey error is defined as the difference between the target universe and the known universe. An indirect correlation exists between the survey error and the data base. As the survey error increases, there is a corresponding decrease in the reliability of the data base (i.e., the known universe) as it represents the target universe (ibid).

The level of survey error is extremely significant in intensive surveys (for more complete discussion, see Thoms 1978). Under current conditions in contract archaeology, undiscovered cultural resources may be considered nonexistent and, as a result, potentially significant portions of the record of past human behavior are excluded from future discussion. The preceding statement reflects the fact that most federal agencies have developed guidelines for implementation of cultural resource management laws. The necessary archaeological investigations are often divided into sequential phases such as: 1) archival and literature search; 2) intensive surveys; 3) test excavation; and 4) final mitigation (often full-scale excavation). While intensive surveys are only a part of the larger concept of cultural resource management, they define the known universe and are an acceptable primary tool for cultural resource managers.

Considering the significance of intensive surveys, it is of paramount importance to minimize the survey error. Conducting the survey with enough intensity to discover a maximum number of cultural resources is the most direct 
way to minimize survey error. Intensity of surface coverage is measured directly by the spacing between individual surveyors (assuming transect coverage of the study area) and secondarily by the rate of coverage (Schiffer, Sullivan, and Klinger 1978:21). However, survey error is not the only factor which conditions the archaeologist's ability to understand the whole of past human behavior.

Seven sources of bias which intervene between human action and the archaeologist's perception of that action may be identified as follows: 1) not all behavior patterns result in patterned material culture; 2) of those which do, not all will occur where there is an opportunity for inclusion in archaeological context; 3) of those so occurring, not all will be included in such context; 4) of those which are included, not al1 will be preserved; 5) of those which are preserved initially, not al1 will survive; 6) of those surviving, not all will be exposed to, or by, the archaeologists; and 7) among patterns exposed to the archaeologist, not al1 will be perceived or properly identified (Collins 1975:29).

Survey error is of course a part of collins's seventh source of bias. The objective of the preceding discussion is simply to make clear that there is a significant difference between the target and the known universes. Furthermore, the archaeologist must be aware of this difference for it conditions his interpretations of past human behavior. The first six of collins's (ibid.) sources of bias are not subject to significant amelioration by the archaeologist. The archaeologist can, however, decrease the level of survey error by striving for greater intensity during the survey.

Obviously, many factors condition the actual level of intensity for any particular project. In contract archaeology, the most apparent conditioning factors are the monetary and temporal restrictions stipulated in the contract. Schiffer, Sullivan, and Klinger (1978) have discussed a variety of controllable and uncontrollable factors which condition the likelihood of encountering cultural resources, i.e., the discovery probability. Uncontrollable factors include the abundance, clustering, obtrusiveness, visibility, and accessibility of archaeological materials; controllable factors include survey techniques and strategy (ibid.).

Many conditioning factors can be minimized by making adjustments during the proposal and/or project stages of an intensive survey. For example, when funding is low, it may be feasible to suggest a sampling design which allows for the desired level of intensity of coverage of representative portions of the study area (see Thoms 1976, for an example of this approach). It may also be possible to modify the proposed survey techniques during the project and still maintain an acceptable level of intensity of coverage. When seasonal environmental conditions limit surface exposure, it may be possible to re-schedule the project. Schiffer, Sullivan, and Klinger (1978) suggest a variety of ways to compensate for the conditioning factors of the intensive survey.

\section{Definitions}

Since 1974 it has been a CRI practice to define the term site, as well as other categories of cultural resources, on a project-by-project basis. In a 
very broad sense, the term site can be defined as "an area in which past human activity has modified the natural environment, usually with the addition of cultural materials" (Thoms and Proctor 1977:18). However, in the Choke Canyon area it is difficult to walk $160 \mathrm{~km}$ without discovering some evidence of past human activity: major portions of the reservoir area could be defined as sites. Much of the scattered cultural debris in Choke Canyon is confined to gravel ridges and represents limited (as evidenced by surface materials) quarry activities. As a result of continual erosion and also brush-clearing activities, many cultural surficial manifestations are almost wholly destroyed. But one encounters a very thin scatter of heat-fractured rock and/or chipped stone debris on many slopes and relatively flat areas. Much of the cultural material on the surface may have been exposed as a result of rodent activity, vegetational processes, normal pedological processes, and/or recent human activities, such as cutting senderos (local term for linear clearances) and building fences or roads.

Considering the above, as well as information derived from background research and our previous experience in the area, we decided to define and categorize observable cultural resources we anticipated discovering in the reservoir area. Definitions presented below were derived during the evening following the first day of survey activities. A site is defined as any area which exhibits 10 or more cultural items, including tools, lithic debitage, heatfractured rock, and faunal remains associated with other more definite cultural artifacts, e.g., lithic debitage, per $25 \mathrm{~m}^{2}$. Following general discussions by Colitins (1975:61-68) and specific suggestions by Schiffer, Sullivan, and K1inger (1978:3), we employ the term low density artifact scatter (originally we used the term non-site); we have defined this term in a subjective manner as an obvious near-site-level concentration of cultural materials. The third category of cultural resources is termed isolated artifact and is defined as a single potentially diagnostic cultural item (or fragment [s] of same), usually a tool, which is not associated with other cultural materials.

\section{Choke Canyon Survey Strategy}

The survey of the 2544 hectares in Choke Canyon Reservoir was designed as an intensive survey. Intensity can be considered the amount of effort devoted to inspecting surveyed areas; it can be controlled by the archaeologist and "has the most profound effect on discovery probabilities. . ." (Schiffer, Sullivan, and K1inger 1978:21). The methods and techniques employed in implementing an intensive survey have varied through time and from project to project. Traditionally, the method of coverage has been pedestrian in nature. During the last few years variations of the transect technique have become commonplace as a means of systematically covering the surface (e.g., see Martin 1973; Thoms 1976; Thoms and Proctor 1977; Beckett and Bussey 1977; Reher 1977; Whaten 1977). This approach has been previously employed in south Texas; examples include the 1976 survey of portions of Hidalgo and Willacy Counties, Texas (Mallouf, Baskin, and Killen 1977:99-100) and several surveys by CAR.

The Cultural Resources Institute (CRI) first employed the transect technique during the summer of 1974 (see Thoms 1976). Since that time all CRI survey projects have employed the transect technique, but in various widths and 
patterns within individual transects. Generally, however, surveyors walk a zigzag pattern within their respective transects.

As previously stated, the proposal for the intensive survey included a research design with specific methods and techniques for conducting the survey. Considering that the planned survey was to be intensive, the primary objective was to locate and record the maximum number of observable cultural resources. The zigzag transect technique was proposed with individuals spaced at approximately $25 \mathrm{~m}$, the width varying depending on environmental conditions. In general, it has become common to have spacing from 10-75 $\mathrm{m}$ when employing the transect technique (Schiffer, Sullivan, and Klinger 1978:22). At the proposal stage it was estimated that a rate of coverage of 12 hectares ( 30 acres) per person per day could be achieved. This estimate was based on CRI's previous survey rates, background research, and general familiarity with the region's environment and potential cultural resources.

Because heavy rains in the spring of 1977 resulted in abnormal vegetational growth in the study area, the survey was delayed until late summer when visibility was greatly enhanced as a result of a prolonged dry period.

\section{Surveys Compared}

During the spring of 1974 and the spring of 1976 some 10,931 hectares $(27,000$ acres) of the reservoir were subjected to an intensive archaeological survey by the Texas Historical Commission (Lynn, Fox, and O'Malley 1977). It is helpful to compare the general nature and results of the THC (1974, 1976) and CRI (1977) surveys. This will provide the reader with an overal1 perspective of the archaeological record in the reservoir area and explain the reasons underlying the differences between the two surveys. Our survey area maps (Figs. 3, 4, 5, and 6) illustrate al1 cultural resources recorded by CRI, as we11 as those adjacent to our survey areas that were recorded during the earlier survey. For a complete documentation of all sites recorded during the previous survey, the reader is referred to Lynn, Fox, and 0'Malley (1977).

There are no statements in this THC report concerning the techniques employed to cover the surface. The report states that 230 work days were spent during the survey, including time to test excavate 11 sites. Based on this figure, we have estimated a survey rate of approximately 53 hectares (131 acres) per person day. During the survey 161 sites were located and recorded. This gives a general site density figure of roughly one site every 68 hectares. Sites ranged in size from 10,000 to $600,000 \mathrm{~m}^{2}$. Most of the sites were located along the Frio River or its major tributaries (Lynn, Fox, and 0'Malley 1977).

The 2544-hectare intensive survey conducted by CRI was completed in 128 person days. With this level of intensity, we were able to average 20 hectares (49 acres) per person day. In the course of the CRI survey, 113 sites were located and recorded. This gives an overall site density of one site every 23 hectares (56 acres). Site size varied from $5 \mathrm{~m}^{2}$ to $385,000 \mathrm{~m}^{2}$. Some sites were situated along the Frio River and its major tributaries, but most were situated away from the major drainage. 
Figure 3. Map of W. W. Walton Property.

PAGE 19 REDACTED

Figure 4. Map of N. H. Schwartz, R. T. McDermott, and J. Davidson Properties.

PAGE 20 REDACTED

Figure 5. Map of C. T. Teal Property

PAGE 21 REDACTED

Figure 6. Map of G. Morrill Property.

PAGE 22 REDACTED 
The obvious question is raised: Why are the results of these two intensive surveys so different? The question is prompted by the fact that the natural environments involved were almost identical and both projects were directed towards recording all observable cultural resources. Similarities and differences between the two projects are summarized in Table 1.

TABLE 1. SURVEYS COMPARED

\section{Previous Survey}

Reason

Location

Topography

Vegetation

Season and year

Cost

Area

Type

Method

Technique

Collection

Procedure

Interval between

surveyors

Number of person

days in field

Rate of coverage

(per person day)

Site definition

Number of sites recorded
Public Law 93-291, for reservoir construction

Choke Canyon reservoir area, south Texas

Dissected plain

Low brush, cultivated

fields, forest

Spring 1974 and 1976

Approximately $\$ 43,000$

10,931 hectares

$(27,000$ acres $)$

Intensive

Pedestrian

Undefined

Site-specific

provenience

Undefined

208 (approximateiy)

53 hectares (131 acres)

Undefined

161

\section{CRI Survey}

Public Law 93-291, for reservoir construction

Choke Canyon reservoir area, south Texas

Dissected plain

Low brush, cultivated fields, forest

Fal1 1977

Approximately $\$ 43,000$

2544 hectares (6285 acres)

Intensive

Pedestrian

Zigzag transect

No collection during survey

65 meters

128

20 hectares (49 acres)

More than 10 artifacts in a $25 \mathrm{~m}^{2}$ area

113 
TABLE 1. (continued)

\begin{tabular}{|c|c|c|}
\hline & Previous Survey & CRI Survey \\
\hline Site size range & $10,000 \mathrm{~m}^{2}$ to $600,000 \mathrm{~m}^{2}$ & $5 \mathrm{~m}^{2}$ to $385,000 \mathrm{~m}^{2}$ \\
\hline $\begin{array}{l}\text { Overal1 site } \\
\text { density }\end{array}$ & $\begin{array}{l}14.7 \text { sites per } \mathrm{km}^{2} \\
(3.8 \text { per section-- } \\
640 \text { acres) }\end{array}$ & $\begin{array}{l}43.5 \text { per } \mathrm{km}^{2} \\
(11.4 \text { per section-- } \\
640 \text { acres) }\end{array}$ \\
\hline $\begin{array}{l}\text { Low density scatter } \\
\text { definition }\end{array}$ & Undefined & $\begin{array}{l}\text { Fewer than } 10 \text { artifacts } \\
\text { in a } 25 \mathrm{~m}^{2} \text { area }\end{array}$ \\
\hline $\begin{array}{l}\text { Number of low } \\
\text { density scatters }\end{array}$ & $0^{*}$ & 43 \\
\hline $\begin{array}{l}\text { Number of isolated } \\
\text { artifacts }\end{array}$ & 0 & 5 \\
\hline $\begin{array}{l}\text { General location of } \\
\text { cultural resources }\end{array}$ & $\begin{array}{l}\text { Most sites along river } \\
\text { and major tributaries, } \\
\text { few away from major } \\
\text { drainage }\end{array}$ & $\begin{array}{l}\text { Sites also along river } \\
\text { and major tributaries, } \\
\text { but most away from major } \\
\text { drainage }\end{array}$ \\
\hline
\end{tabular}

Despite numerous similarities, the CRI survey resul.ted in an overall site density approximately three times greater than that of the previous survey. The CRI survey recorded 75 sites smaller than the smallest site recorded during the previous survey, and 18 of these were smaller than $500 \mathrm{~m}^{2}$. Furthermore, many sites recorded by CRI were located in areas similar to those where no sites had been previously recorded. It is doubtful that actual settlement pattern differences account for these results since in many cases the two survey areas were separated only by fences. Furthermore, climatological and vegetational conditions were similar during both surveys, and land access to the areas covered was not a major problem for either survey. Given the above situation, the uncontrollable factors--abundance, clustering, obtrusiveness, visibility, and accessibility of archaeological materials (Schiffer, Sullivan, and Klinger 1978)--do not account for the differences between the two surveys.

Once the comparisons are made between the two surveys, it is possible to suggest several reasons for the different results. The following statements are based on comparing the results and on information gathered or deduced from the larger survey which was not included in the final report. Economics and controllable survey factors--survey techniques and strategies (ibid.) account for most of the observed differences.

Many of these differences between the results of the two projects can be explained by the fact that both projects were undertaken for essentially the same amount of money (approximately $\$ 43,000$ ). Roughly $\$ 3.93$ was available to survey each hectare of the 10,931-hectare area as compared to $\$ 16.91$ for the 2544-hectare area. It should be noted that approximately 22 person days were

*Some may have been recorded as sites. 
devoted to testing sites in the larger area and 40 person days were spent testing sites in the 2544-hectare area. With available funds almost equal, it is obvious that this conditioned the intensity of the larger survey more than that of the smaller survey.

Both surveys were pedestrian in nature, but specific strategies probably differed considerably. During the small survey equal attention was given to al1 areas. This was presumabiy not the case with the larger survey because large areas were declared void of cultural resources; sites were recorded in areas similar to these during the smaller survey. Considering the number of cultural resources recorded during the two surveys, the level of intensity also differed between the projects. This is also made evident by examining the distribution of sites. The observed site size differences probably reflect differing site definitions employed during the two surveys. More detailed comparisons between the two intensive surveys are rendered almost impossible because the final report of the larger survey did not include a discussion of the research design at the technique level, nor did the report detajl the manner in which the survey was actually carried out.

\section{Implementation}

During the pre-proposal, proposal, and pre-field stages of the 1977 CRI project and as late as the first several days of the field stage, no decisions were made by the contracting agency or by the prime contractor regarding which of the unsurveyed areas of the reservoir would be surveyed by CRI. During discussions with Bureau of Reclamation personnel, it became apparent that only certain land tracts had been condemned and/or purchased by the Bureau. In the final analysis, accessibility to land tracts determined which area CRI surveyed. Acreage surveyed by CRI is shown in Figure 1.

Considering that the areas for intensive survey were already determined, it was not necessary to develop a sampling design to select a representative sample of areas to be covered. Rather, our research design stipulated that al1 areas would be subject to the same techniques of surface coverage. The primary problem was then to employ a survey strategy that would allow us to effectively and efficiently complete the survey within the limits of available monetary and temporal resources.

The survey began in the southern portion of the Walton property adjacent to the Frio River. Our technique for covering the area was to visually divide it into parcels of contiguous transects approximately $25 \mathrm{~m}$ (distance was paced) wide. Individual parcels within specific land tracts general1y exhibited existing boundaries, such as fences, roads, senderos, and drainages. The parcels were selected because they were distinct units which were also indicated on the topographic maps, and their size was small enough to minimize logistical problems. Each day's survey was initiated along and parallel to a distinctive boundary (e.g., fence, sendero, or drainage). Each individual walked a zigzag pattern within his 25-m transect; an effort was made to insure some overlap between transects. Due to the very dense brush, which at times limited visibility to less than $5 \mathrm{~m}$, it was decided that the outside surveyor (Thoms and Montgomery always held both outside positions), or the individual 
farthest from the distinctive boundary of the parcel, would mark the limits of his transect with wire flags. Upon completing a transect, the individual who set the flags would return on the adjacent transect and collect the flags while another surveyor marked the outside limits of the new sweep (equivalent to four transects) by setting another line of wire flags. The two individuals responsible for the middle transects kept in continual visual and/or verbal contact with surveyors to their right and left. A combination of setting wire flags and continual communication among crew members provided reasonable assurance that we were not missing large areas.

Once cultural resources were encountered by one surveyor, the others marked their progress with wire flags or flagging tape, walked to the location of the observed cultural materials, and documented the occurrence; with the exceptions of isolated artifacts, no collections were made during the survey.

\section{Procedures}

Individual crew members documented the site as follows: 1) Montgomery took at least two photographs of the site, plus photographs of individual features (if present); he drove in a metal stake and attached an embossable aluminum label identifying the site and marked its location with two or three streamers of pink flagging tape; he also completed the UTSA computerized site forms and conducted a brief reconnaissance of the site, recording notes in his field notebook; 2) Jurgens and Alvey divided the site into two parts, each being responsible for documenting half of the site; they each drew rough sketch maps (distances by paced measurements) indicating areas of concentrated cultural debris and evident features as well as the site's dimensions; they flagged the site's limits with yellow flagging tape and marked obvious tools and features (e.g., hearths and artifact concentration areas) with pink flagging tape; 3) Thoms took detailed notes based on his examination of the site and information provided by other crew members; he also completed the TTU site form and drew a sketch map, which indicated approximate contour lines, site dimensions, location of artifact concentration areas, other features and tools, and the site marker. The process of documenting sites in the above manner and returning to the appropriate starting position generaliy took from $45-90$ minutes, depending upon the nature of the cultural resource.

We were very fortunate to have available copies of the Bureau's detailed 2-inch contour interval topographic maps. The maps were recently compiled especially for the Choke Canyon Reservoir construction project. The copies we used in the field were at a scale of 1 inch equals 800 feet; they were extremely accurate (except in a few instances where vegetation obscured topography) and also indicated major vegetational areas, most roads, trails, senderos, fences, and existing buildings. With such detailed maps available we were able to accurately plot sites. However, available copies were limited to two for field work and one for laboratory work. Thoms and Montgomery carried the Bureau maps while Jurgens and Alvey carried USGS 7.5' topographic maps. 


\section{Procedural Changes}

As previously stated, a major problem was to develop an effective and efficient survey strategy (based on our proposal) that would allow us to complete the survey within two months and still have sufficient time to carry out a surface collection/test excavation program at a representative sample of sites as supplementary investigations. The survey strategy discussed in the preceding section was employed at the outset of our survey. During the first few days of field work the survey strategy resulted in a rate of coverage ranging from 4-8 hectares per person day. While this was effective, it was not very efficient. Our lack of efficiency was attributed to the following conditions: 1) a transect width too narrow; 2) four crew members documenting every site; 3) difficulty in communications among crew members; 4) routine slow progress during initial work days; 5) very thick brush, primarily acacia, which made crawling a part of each day's work; 6) hot and humid weather; and 7) constant apprehension about discovering rattlesnakes (which was justified throughout the survey).

It was necessary to achieve an average rate of coverage of 19 hectares

(47 acres) per person day if we were to complete the survey within the allotted time. We soon learned to cope with environmental conditions as well as to understand the general nature of the cultitural resources; the result was an increase in our rate of coverage. However, it was necessary to modify the survey technique if we were to achieve the desired rate of coverage. After experimenting with several transect widths, we discovered that a width of $65 \mathrm{~m}$ (when coupled with other factors) would yield the desired rate of coverage. We also wanted to know how walking a zigzag pattern in a $65-\mathrm{m}$ transect compared to walking a straight-line pattern. In order to gather information on distances walked using the zigzag technique, each crew member used a pedometer. Distances walked using the pedometer were consistent among a11 crew members. The zigzag pattern resulted in walking 2 1/2-3 times the straight-line distance of any given transect (straight-line distances were measured on maps).

We continued to work as one group surveying four contiguous transects, but with two-person crews. Using this approach, only two individuals recorded any given site, unless a site was observed in three or more transects. Crews were Thoms/Jurgens and Montgomery/A7vey. Thoms and Montgomery took detailed notes on each site his crew discovered, completed the TTU survey form (including the sketch map). and examined the site to verify data supplied by the field assistants. Jurgens and Alvey flagged the site's 1 imits, as well as potentially diagnostic tools and features. They also placed and labeled the site marker, took photographs, completed the UTSA site survey forms, and recorded brief site specific comments in their field notes. In most cases 30-60 minutes were spent recording individual sites. After three weeks of survey work we acquired two FM transceivers which were carried by Thoms and Montgomery for the remainder of the survey. The transceivers were extremely useful and aided significantly in increasing our rate of coverage. Other aspects of the survey strategy remained as discussed earlier. By the tenth day of survey work the techniques described above (with the exception of the FM transceivers) were fully implemented and were employed throughout the survey. During the survey the rate of coverage varied from 4-40 hectares per person day. As has been noted, vegetation density and surface visibility 
varied considerably throughout the study area, and this accounts for most of the variation in the survey rate. In a71, 128 person days (i.e., each day a surveyor was in the field more than four hours) were spent surveying 2544 hectares (6285 acres). The overall average survey rate was 20 hectares

(49 acres) per person day.

\section{Survey Data}

A large number of site specific attributes were monitored during the CRI survey. These data were considered relevant to the research design which has been discussed in the preceding section of this report. Information was documented on TTU and UTSA site survey forms (see Appendix I) as well as in individual field notes. In addition to information specifically requested on site survey forms, we monitored other site attributes which might be considered project specific attributes. These additional attributes were generaliy listed on site survey forms, but at times they were listed in field notes. Project specific attributes included visual estimates (agreed upon by all crew members examining the site) of overall artifact density per square meter; number of hearths; percentages of heat-fractured rock and chipped stone (the two total $100 \%$ ); percentages of primary, secondary, and interior flakes (total of 100\%); and percentage of undisturbed portion of the site. No collections were made; sketches were made of all observed chipped stone tools and many of the ground stone tools. Low density artifact scatters were described (e.g., location, size, types, and quantity of materials) in field notes and on topographic maps. Isolated artifacts were collected, documented on CRI site survey forms (without a sketch map), and plotted on the topographic map.

\section{Supplementary Investigations}

The supplementary field investigations were conducted in a testing program which consisted of both surface and subsurface testing procedures. The term testing is used not in a narrow sense implying excavation, however limited, but in a broad sense of intensively examining a sample of previously observed cultural resources, by surface and/or subsurface means. In this project, there were two phases of field work: phase one, the survey; phase two, the supplementary investigations (testing).

After the intensive survey of the area was completed, a representation sample of sites to undergo supplementary field investigations was drawn. The procedures used in selecting these sites are described in the next major section of this chapter.

\section{Surface Testing Procedures}

Surface documentation of archaeological sites has in recent years become an important research tool in archaeology. The utility of several methods of surface collecting and the usefulness of the data in predicting subsurface evidence can be traced back to several important projects from South America (Mayer-Oakes 1970:2-5)., the Near East (Redman and Watson 1970), and North America (Binford et al. 1970). Beginning at this time, the term intensive 
systematic surface collection became a common phrase for describing an important archaeological tool for documenting surface manifestations and predicting subsurface archaeological remains. Refinements in methodology and technique have led to the analysis of surface patterns by nearest neighbor analysis (cf. Whallon 1974), dimensional analysis of variance (cf. Whallon 1973), chi square analysis (cf. Dacey 1974), and factor analys is (cf. Healar 1972; Downer 1977; Gunn and Mahu1a 1977). Downer (1977) has recently pointed out that certain techniques which seek to define spatial patterning of surface remains from quantitative geography and plant ecology utilize contemporary data, and that mixing of temporally different materials can cause spurious results in archaeological situations. Other recent discussions of site surface sampling are contained within Redman (1975) and Asch (1975).

CRI has made systematic surface collections in several projects. The Canyon Lakes project (Keslin et al. ms.) incorporated a proportionately stratified random sample design. Another project involved transect sampling of an extensive Jornada structural site near ET Paso, Texas (Portnoy 1977). Various sampling schemes have been employed in our archaeological survey projects (cf. Thoms 1976; Thoms and Proctor 1977).

Surface collection procedures followed by the CRI Choke Canyon project are detailed below. They incorporate a random selection of surface:collection units in a fashion which expended the least amount of time and yet insured useful results.

Our testing program provided systematic surface collections at every site scheduled for additional work. Prior to field testing procedures, field maps of all sites to be tested were transferred to gridded paper. This was accomplished with the aid of a Kargl reflecting projector, which enlarged the original field maps. The original field maps were already made on 2-inch contour topographic maps of a scale 1 inch equals 800 feet. The resulting scale on the gridded site maps was such that each grid square on the new map corresponded to $4 \mathrm{~m}^{2}$. This was important, because at each site one or more 4-m² grid units were used in the surface collection procedures. Without these maps from the Bureau of Reclamation, the testing procedures would have been more difficult and time consuming.

In the field, the sequence of activities was as follows:

1) Move the site marker stake to a map grid point as close to the center of the site as possible;

2) Recheck and if necessary redefine the site boundaries and draw them on the map;

3) Number every grid unit which is at least halfway within the site boundaries, beginning with the most northwestern grid unit and moving from left to right;

4) Estimate the area of the site (in $\mathrm{m}^{2}$ ) and determine the number of $4-\mathrm{m}^{2}$ grid units necessary to achieve a $1 \%$ coverage of the site's surface. If the number of grid units needed to sample $1 \%$ of the surface is too large to 
handle within our time framework, a lower percentage level is used;

5) Use a table of random numbers to select the necessary $4-m^{2}$ grid units for each site;

6) Locate the southeast corner of each $4-\mathrm{m}^{2}$ grid unit with a transit and stadia rod or with the Bandy surface surveyor (Bandy 1977);

7) Two-tape in each $4-\mathrm{m}^{2}$ string grid along true north with chaining pins at the four corners; mark the string in $1 \mathrm{~m}$ units and collect all artifacts and ecofacts from each $1 \mathrm{~m}^{2}$. (This step was later simplified by constructing a portable wooden grid which takes only 5-10 minutes to set up.)

Due to time restraints, the surface collections were performed at low percentage levels. At sites of large areal extent, on $7 y 0.25 \%$ to $0.50 \%$ of the site's surface was systematically collected. At smaller sites, up to $1 \%$ of the site's surface was systematically collected.

As time allowed, additional potentially diagnostic tools were recorded and collected outside the collection units. Provenience was recorded by using a transit and tape and the Bandy surface surveyor (ibid.). The transit and stadia rod were also used to record provenience of surface artifacts and features which were described in detail and photographed.

\section{Subsurface Testing Procedures}

Eleven of the 15 tested sites contained naturally exposed profiles in cutbanks which indicated the depth of cultural deposits and the stratigraphy at the site. At three tested sites, test pits were excavated at appropriate locations to document this information. The locations of test pits were subjectively determined by the archaeologists. The remaining site contained a massive borrow pit (excavated by BOR) which exhibited cultural deposits and site stratigraphy in the existing profiles. Some materials were collected from backdirt piles of BOR borrow area head pits; we refer to these collections as uncontrolled grab samples.

The following sequence of activities was followed in the field for collection of soil samples. The test pits were excavated in arbitrary levels whose thickness was normally $10 \mathrm{~cm}$. All test pits were $1 \mathrm{~m}^{2}$ in size. Within each level, a $10 \mathrm{~cm}^{2}$ area was left unexcavated until the remainder of the level was completed. This cube was the soil sample for the particular level of the test pit, and its location was the extreme northwest or southwest corner. If a feature was indicated in or near one of these two corners, the other corner was chosen for removal of the soil sample, thus allowing full disclosure of any features. The soil sample cube was prepared after all other level activities (screening, excavating, recording, photographing) had been finished. A clean trowel was used to face all exposed sides of the soil sample before removal. All samples were carefully removed to minimize contamination. 
Field notes describing the soil samples and the site's general environmental situation were maintained throughout the project.

\section{Supplementary Investigation Data}

The supplementary investigations provided collections of artifacts and ecofacts (e.g., she11, heat-fractured rock, soil samples) that were later subjected to laboratory analysis. Information about hearths and other features was recorded.

\section{Procedures Used in Selecting Sites for Supplementary Investigations}

When the intensive survey was completed, 111 sites had been recorded. The next field stage consisted of supplementary investigations. Project needs and resources indicated that about $10 \%$ of the sites could be further studied in the field. It was essential that this sample should reflect the entire range of site variability and be representative of the total group of sites. This suggested that the total population of sites be stratified before the $10 \%$ sample was drawn, and that the sample be drawn proportionately from each stratum.

During the previous (THC) survey, sites were classified (i.e., the total population [or universe] of sites was stratified) according to their topographic setting. Sites were selected from each class for additional field investigations (Lynn, Fox, and O'Malley 1977). Rather than use only one variable to stratify the population of sites recorded during the CRI survey, we decided to use a large number of both environmental and cultural variables, and to try to do this as objectively as possible.

The archaeological literature describing procedures to sample populations is immense and can be only briefly noted here. The use of research designs based on the principles of probability sampling was established by Rootenberg (1964) and Binford (1964), which led to a wave of archaeological research along these lines. Recent summaries and overviews of archaeological sampling (cf. Flannery 1976; Mueller 1974, 1975) contain detailed information and examples.

\section{Site Variables}

After studying the completed TTU and UTSA survey forms and the field notes for the 111 recorded sites, we decided to use 19 variables (site attributes) that we felt could adequately and objectively describe the variability among the sites. These variables and how they were expressed are shown in Table 2.

\section{Site Selection Procedure}

The dimensions of variability appear in what is in effect a 111 by 19 matrix, which describes al1 111 sites in terms of al1 19 variables. This is too cumbersome for effective analysis--we needed a way to reduce these dimensions 
TABLE 2. SITE VARIABLES

1. Topographic Setting.

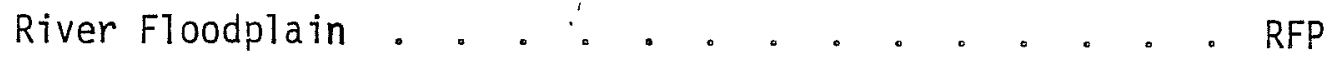

River Terrace •. •. . . . . . . . . . . RTE

River Valley Wall . . . . . . . . . . . . RVW

Primary Tributary Floodplain . . . . . . . . . PTF

Primary Tributary Terrace . . . . . . . . . . PTT

Primary Tributary Valley Wall . . . . . . . . . PTW

Secondary Tributary Floodplain. . . . . . . . STF

Secondary Tributary Terrace. . . . . . . . . . STT

Secondary Tributary Valley Wall . . . . . . . . STW

Minor Tributary Floodplain . . . . . . . . . MTF

Minor Tributary Terrace . . . . . . . . . . . MTT

Minor Tributary Valley Wal1. . . . . . . . . . MTW

Upland. . . . . . . . . . . . . . . . . . UPL

2. Elevation - feet above mean sea level . . . . . (MSL)

3. Soil Types

Sandy Loam . . . . • . . . . . . . . . . . SLM

Sandy Clay . . . . . . . . . . . . . SCL

Sandy Loam and Sandy Clay plus Gravels....... LCG

Calcareous Sandy Clay. . . . . . . . . C CSC

Calcareous Sandy Loam. . . . . . . . . . . CSL

Calcareous Sandy Loam and Sandy Clay and Gravels. . . CSG 
TABLE 2. (continued)

Soil Types

Sandy Loam with Gravels . . . . . . . . . . SLG

Sandy Clay with Gravels .'. . . . . . . . . SCG

4. Estimated Distance from Permanent Water

On Site. . . . . . . . . . . . . . . 01

Within $100 \mathrm{~m}$........... . . 02

$100 \mathrm{~m}-1 \mathrm{~km}$. . . . . . . . . . . . . 03

Greater than $1 \mathrm{~km} \cdot . .+. . . . . .04$

5. Estimated Distance from Seasonal Water

On Site. . . . . . . . . . . . . 01

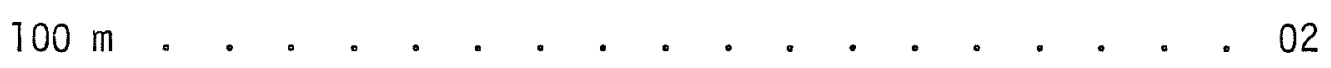

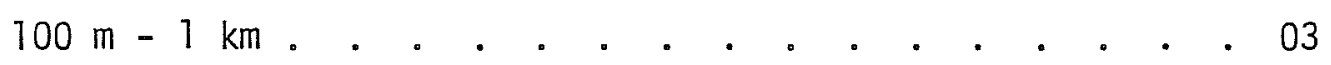

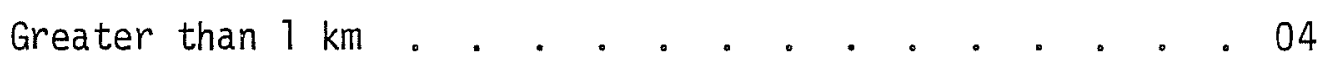

6. Estimated Size

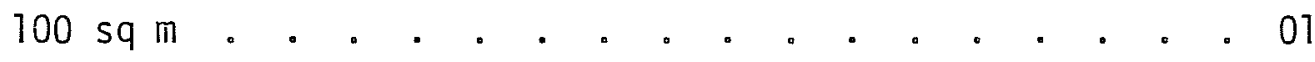

$150-900 \mathrm{sqm}$. . . . . . . . . . 02

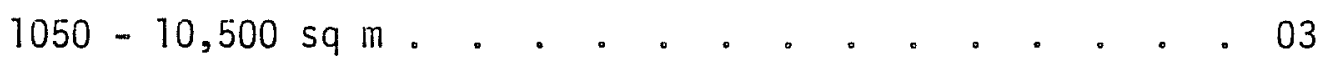

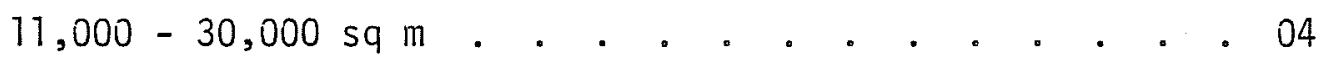

35,000-75,000 sq m . . . . . . . . . . 05

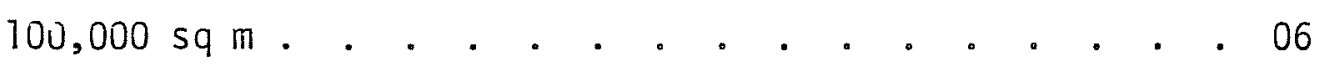

7. Major Type of Heat-Fractured Rock and Presence of Mussel Shel1

Chert . . . . . . . . . . . . . . BFT

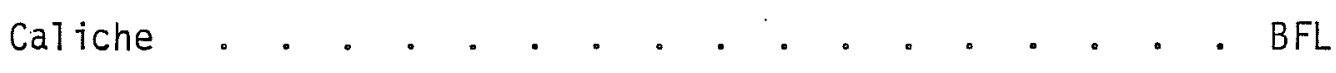

Sandstone . . . . . . . . . . . . . . BFS 
TABLE 2. (continued)

Major Type of Heat-Fractured Rock and Presence of ifussel She11

Chert with Mussel . . . . . . . . . . . . . BTM

Caliche with Mussel. . . . . . . . . . BLM

Sands tone with Musse1 . . . . . . . . . . . . BSM

Ecofacts Absent . . . . . . . . . . . XXX

8. Estinated Flake Type Occurence

Most Interior . . . . . . . . . . . . . . FLI

Plost Secondary . . . . . . . . . . . FLS

Wost Primary . . . . . . . . . . . . FLP

$1 / 2$ Interior $1 / 2$ Secondary . . . . . . . . FIS

$1 / 2$ Interior $1 / 2$ Primary . . . . . . . . . FIP

1/2 Secondary $1 / 2$ Primary . . . . . . . . FSP

9. Estinated Number of Hearths

None. . . . . . . . . . . . . 01

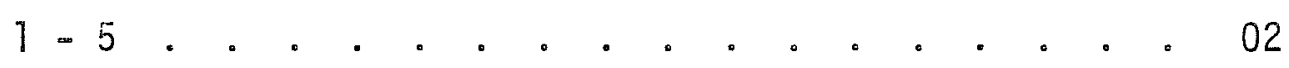

$6-20$. . . . . . . . . . . 03

$21-50$. . . . . . . . . . . 04

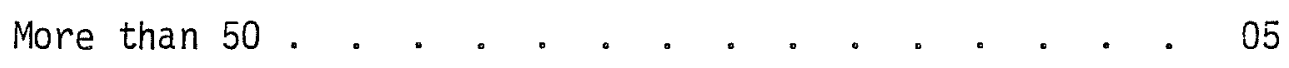

10. Estimated Overa11 Density of Cultural Items

0 - 4 items per sq m. . . . . . . . 01

5 - 9 per sqm.......... . . . 02

$10-24$ per sqm............. . . . . 03

25 - 49 per sq m. . . . . . . . . . . . 04

50 - 99 per sqm. . . . . . . . . . . . 05

More than 100 per sq m. . . . . . . . . . . . 06 
TABLE 2. (continued)

11. Estimated Percentage of Heat-Fractured Rock . . . . 0-100\% (by $10 \%$ interva 15 )

12. Estimated Percentage of Chipped Stone . . . . . 0-100\% (by $10 \%$ intervals)

(Totals of 11 . plus 12 . must equal $100 \%$ )

13. Presence of Cores

Cores Present . . . . . . . . . . . . . . . P

Cores Absent . . . . . . . . . . . . . A

14. Presence of Thick Bifaces

Thick Bifaces Present . . . . . . . . . . . . P

Thick Bifaces Absent . . . . . . . . . . . A

15. Presence of Thin Bifaces

Thin Bifaces Present . . . . . . . . . . . . . P

Thin Bifaces Absent . . . . . . . . . . . . . A

16. Presence of Unifaces

Unifaces Present . . . . . . . . . . . . . . P

Unifaces Absent . . . . . . . . . . . . A

17. Presence of Ground Stone

Ground Stone Present . . . . . . . . . . . . . P

Ground Stone Absent . . . . . . . . . . . . A

18. Presence of Prehistoric Pottery

Prehistoric Pottery Present. . . . . . . . . . . . P

Prehistoric Pottery Absent . . . . . . . . . . A 
TABLE 2. (continued)

19. Presence of Historic Items

Historic European Materials Present . . . . . . . P

Historic European Materials Absent . . . . . . . A

without losing the range of variability. To do this, a Q-mode factor analysis with principal components was applied to the survey data. We used the Texas Tech University IBM 370 computer and the FACTOR program in the SAS software package (Service 1972). We were assisted by Dr. Stuart H. Pimm of the TTU Biology Department and by programmers and consultants at the TTU Computer Center.

Principal components analysis reduces the dimensions of the variability by producing a small number of factors which represent the majority of the variance in the data set (Doran and Hodson 1975:191). The basic character of the data (sites and site variables) has not been changed; the data have been algebraicaliy transformed to provide a more parsimonious examination of the variation among the sites. The entire range of variation is expressed in a way in which it is more easily visualized and dealt with.

The principal components analysis reduced the matrix of 111 sites by 19 variables into several components. The first two components were used in subsequent procedures because they retained the most variance in the original data. That is, the variation expressed by the 19 variables for each site was transformed into two components which summarized most of the variation. Each site was given a score (called a Z-score) for each of these two components. The sites were plotted on a scattergram (Fig. 7), positioned along the X-axis by their first principal component score (Z1) and along the $Y$-axis by their second principal component score (Z2).

\section{Site Selection Resuits}

The scattergram (Fig. 7) showed a generally linear relationship with no clear-cut groups or clusters. This linear relationship indicates that the variability among sites is very gradual: difference can be expressed as a series of grades which flow into each other. One way to sample from a linear grouping is to establish arbitrary interval markers along one of the scattergram axes (Dr. Stuart H. Pimm 1977, personal communication). The data were divided into sets along the first component axis (by $Z 1$ scores). Figure 7 shows how five groups were formed. Group A had scores from 0-30; B had scores 30-40; $C$ had scores 40-50; $D$ had scores 50-60; $E$ had scores 60-70. These five groups formed the strata of the total population of sites from which samples could be drawn. The sites in each group are listed in Table 3.

The number of sites in each group was counted. Group A had 8 sites; B had 10; $C$ had 24; $D$ had 59 ; and $E$ had 10. A $10 \%$ sample would consist of a total of 11 sites; these were allocated proportionately to each stratum. Group A had 1 site; $B$ had 1 ; $C$ had 3 ; $D$ had 5 ; and $E$ had 1 . These were drawn at random 


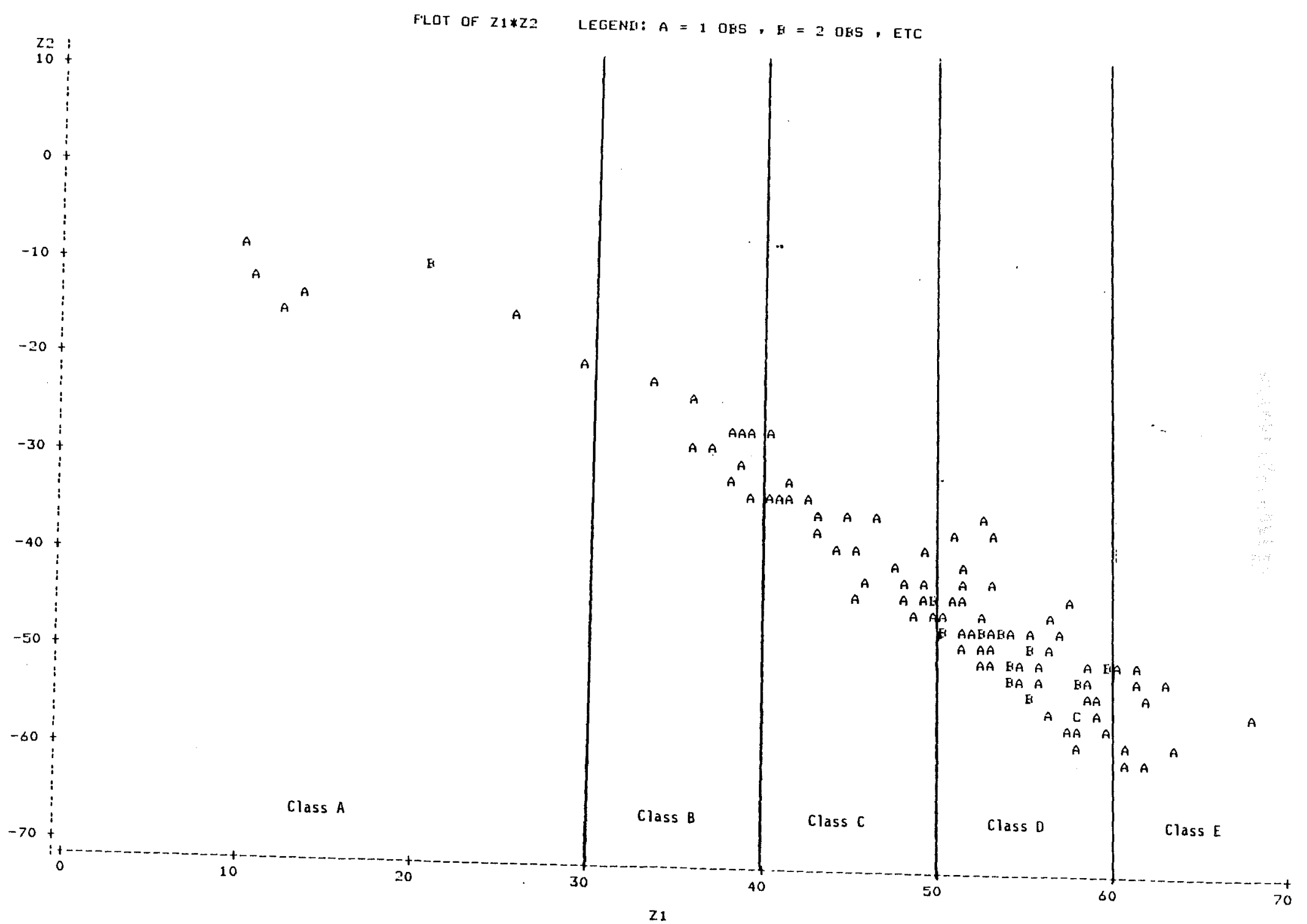

NOTE: SAS INSTITUTE INC., P.0, GOX 10066, RALEIGH, N.C. 27605 
with the following results: 41 LK 152 came from Group A; 41 LK 32 from B; 41 LK 121, 41 LK 183, and 41 LK 199 from C; 41 LK 119, 41 LK 210, 41 LK 159, 41 LK 171, and 41 MC 225 from $D ; 41$ MC 217 from $E$. These sites would receive supplementary investigation in the field.

It has been demonstrated (cf. Mayer-Oakes and Nash 1965; Flannery 1976;

Raab 1977) that if other sites are professionally judged to have unique data potential, they should be added to sites chosen through probability sampling. Four sites, 41 LK 31, 41 MC 201, 41 MC 209, and 41 MC 219, were chosen on this basis and were also scheduled for additional field work, bringing the total to 15 sites. This would have resulted in about a $13 \%$ sample of the total population (111) of sites; this percentage did not change appreciably when two more sites were recorded during the second stage of field work, for a total of 113 sites.

TABLE 3. SITES IN EACH GROUP

Group A (9 sites)

\begin{tabular}{|c|c|c|c|c|}
\hline $\begin{array}{l}47 L K 123 \\
41 L K 134\end{array}$ & $\begin{array}{l}\text { 47LK136 } \\
41 L K 140\end{array}$ & $\begin{array}{l}\text { 41LK152 } \\
41 L K 153\end{array}$ & $\begin{array}{l}\text { 41LK197 } \\
41 L K 202\end{array}$ & $47 M C 214$ \\
\hline \multicolumn{5}{|c|}{ Group B (10 sites) } \\
\hline $\begin{array}{l}\text { 41LK31 } \\
47 \text { LK32 }\end{array}$ & $\begin{array}{l}47 L K 126 \\
41 L K 127\end{array}$ & $\begin{array}{l}\text { 41LK148 } \\
47 L K 187\end{array}$ & $\begin{array}{l}\text { 41LK190 } \\
\text { 41LK198 }\end{array}$ & $\begin{array}{l}\text { 41 LK199 } \\
41 \text { MC226 }\end{array}$ \\
\hline \multicolumn{5}{|c|}{ Group C (25 sites) } \\
\hline $\begin{array}{l}\text { 41LK120 } \\
\text { 41LK121 } \\
41 L K 132 \\
41 L K 147 \\
47 L K 149\end{array}$ & $\begin{array}{l}\text { 41LK150 } \\
41 L K 151 \\
41 L K 163 \\
41 L K 165 \\
\text { 41LK168 }\end{array}$ & $\begin{array}{l}\text { 41LK170 } \\
41 \mathrm{LK} 175 \\
41 \mathrm{LK} 182 \\
41 \mathrm{LK} 183 \\
41 \mathrm{LK} 184\end{array}$ & $\begin{array}{l}\text { 41LK185 } \\
\text { 41LK186 } \\
\text { 41LK188 } \\
\text { 41LK191 } \\
\text { 41LK195 }\end{array}$ & $\begin{array}{l}41 L K 201 \\
41 \mathrm{MC} 197 \\
41 \mathrm{MC} 199 \\
41 \mathrm{MC} 205 \\
41 \mathrm{MC} 207\end{array}$ \\
\hline
\end{tabular}

Group D (59 sites)

$\begin{array}{lclll}41 L K 118 & 41 L K 141 & 41 L K 162 & 41 L K 181 & 41 M C 203 \\ 41 L K 119 & 41 L K 142 & 41 L K 164 & 41 L K 189 & 41 M C 204 \\ 41 L K 124 & 41 L K 143 & 41 L K 166 & 41 L K 192 & 41 M C 206 \\ 41 L K 125 & 41 L K 146 & 41 L K 167 & 41 L K 193 & 41 M C 208 \\ 41 L K 128 & 41 L K 154 & 41 L K 169 & 41 L K 194 & 41 M C 210 \\ 41 L K 129 & 41 L K 155 & 41 L K 171 & 41 L K 196 & 41 M C 211 \\ 41 L K 130 & 41 L K 156 & 41 L K 172 & 41 L K 200 & 41 M C 213 \\ 41 L K 131 & 41 L K 157 & 41 L K 176 & 41 M C 196 & 41 M C 215 \\ 41 L K 133 & 41 L K 158 & 41 L K 177 & 41 M C 198 & 41 M C 216 \\ 41 L K 135 & 41 L K 159 & 41 L K 178 & 41 M C 200 & 41 M C 218 \\ 41 L K 137 & 41 L K 160 & 41 L K 179 & 41 M C 201 & 41 M C 225 \\ 41 L K 138 & 41 L K 161 & 41 L K 180 & 41 M C 202 & \\ \text { Group E (10 sites) } & & & \\ 41 L K 122 & 41 L K 144 & 41 L K 173 & 41 M C 209 & 41 M C 217 \\ 41 L K 139 & 41 L K 145 & 41 L K 174 & 41 M C 212 & 41 M C 227\end{array}$




\section{RESULTS OF THE PROJECT}

Field and Laboratory Analysis

When the two stages of field work (intensive survey and supplementary investigations) had been completed, all records and collected materials were brought back to the CRI project laboratory at TTU; 1aboratory analysis and report preparation began.

Information about the 111 sites recorded and the materials observed, but not collected, during the intensive survey (and about the two additional sites recorded during supplementary investigations) was entered on TTU and UTSA survey forms (Appendix I.) and in field notes kept by each crew member. Photos and sketches were also made. Information gained during the survey is presented in Tables 4 and 5 and discussed later in this chapter. Sites are plotted on the survey unit maps (Figs. 3, 4, 5, and 6). The 43 low density artifact scatters located and the five isolated finds collected during the survey are also plotted on these maps. The low density scatters are described in Table 6.

It should be noted that some of the information in Tables 2, 4, and 5 appears as ranges rather than as absolute values. This reflects how it was recorded on the UTSA site survey forms. For example, estimated distances from permanent and seasonal water sources were recorded as being on site, less than $100 \mathrm{~m}$ from the site, $100 \mathrm{~m}$ to $1 \mathrm{~km}$ from the site, or greater than $1 \mathrm{~km}$ from the site. It has already been noted (in the preceding chapter in the discussion of survey procedures) that some site attributes listed (in Tables 2, 4, and 5) are based on visual estimates agreed upon by a11 crew members examining the site.

The supplementary field investigations (surface and/or subsurface testing) of 15 sites yielded site maps and photos; feature forms, drawings, and photos; surface collection unit forms, photos, and collected materials; controlled grab sample records and collected materials; some materials from uncontrolled grab samples from backdirt piles from BOR borrow area head pits; test excavation unit level forms, photos, and excavated materials; and soil and charcoal samples. Specific information about each site is discussed and figures (maps, drawings, photos) noted in the description of each site appear later in this chapter.

The materials collected from each of the 15 sites were treated in various ways. Heat-fractured rock was weighed; mussel and gastropod she11s were counted. Lithic artifacts were measured, morphologically described, and separated into like-sized and shaped and other categories (see Table 7). Historic artifacts were described, counted and measured where appropriate, and identified when possible. Other items were appropriately recorded and described. Charcoal samples from sites were sent to UTSA for inclusion in their collection of samples to be radiocarbon tested. Soil samples from sites were sent to Dr. B. L. Allen of the TTU Plant and Soil Science Department for testing. 
Keys to the notation used for topography, soil, distances from permanent and seasonal water, and density of cultural materials appear in Table 2.

Survey units are as follows: 1 - W. W. Walton; 2 - George Morri11; 3 - H. N. Schwartz; 4 - R. T. McDermott; 5 - J. Davidson; and 6 - C. T. Neal.

Vegetational associations are described in the chapter "Environmental Setting."

\begin{tabular}{|c|c|c|c|c|c|c|c|c|c|c|}
\hline $\begin{array}{l}\text { Site } \\
\text { Number }\end{array}$ & $\begin{array}{c}\text { Survey } \\
\text { Unit }\end{array}$ & $\begin{array}{l}\text { Veg. } \\
\text { Assoc. }\end{array}$ & Topography & $\begin{array}{l}\text { Elev; } \\
\left(\mathrm{ft}_{\mathrm{o}}\right)\end{array}$ & Soil & $\begin{array}{l}\text { Distance } \\
\text { from } \\
\text { permanent } \\
\text { water }\end{array}$ & $\begin{array}{l}\text { Distance } \\
\text { from } \\
\text { seasonal } \\
\text { water }\end{array}$ & $\begin{array}{l}\text { Size } \\
(\mathrm{sq} \mathrm{m})\end{array}$ & $\begin{array}{c}\text { Depth } \\
(\mathrm{m})\end{array}$ & Density \\
\hline 41LK31 & 3 & 6 & RFP & 160 & SLM & 2 & 2 & $2250^{\circ}$ & 3.0 & 1 \\
\hline 41LK32 & 3 & $1 / 6$ & RFP & 165 & SLM & 3 & 2 & 1200 & 3.0 & 1 \\
\hline 41LK118 & 1 & 6 & PTT & 180 & LCG & 3 & 2 & 150,000 & 0.5 & 1 \\
\hline 41LK119 & 1 & $2 / 6$ & PTT & 170 & LCG & 3 & 2 & 37,500 & 1.0 & 1 \\
\hline 41LK120 & 1 & 6 & RTE & 180 & LCG & 3 & 3 & 19,500 & 0.5 & 1 \\
\hline 41LK121 & 1 & 3 & RTE & 166 & LCG & 3 & 2 & 2975 & 1.0 & 1 \\
\hline $41 L K 122$ & 1 & 6 & UPL & 190 & SLM & 3 & 3 & 150,000 & 0.5 & 1 \\
\hline 41LK123 & 1 & 3 & UPL & 200 & SLM & 3 & 3 & 7800 & 1.5 & 2 \\
\hline 41LK124 & 1 & $2 / 3$ & STT & 166 & SLM & 4 & 2 & 18,000 & 0.5 & 1 \\
\hline
\end{tabular}


TABLE 4. (continued)

\begin{tabular}{|c|c|c|c|c|c|c|c|c|c|c|}
\hline $\begin{array}{l}\text { Site } \\
\text { Number }\end{array}$ & $\begin{array}{l}\text { Survey } \\
\text { Unit }\end{array}$ & $\begin{array}{l}\text { Veg. } \\
\text { Assoc. }\end{array}$ & Topography & $\begin{array}{l}\text { Elev. } \\
(\mathrm{ft})\end{array}$ & Soil & $\begin{array}{l}\text { Distance } \\
\text { from } \\
\text { permanent } \\
\text { water }\end{array}$ & $\begin{array}{l}\text { Distance } \\
\text { from } \\
\text { seasonal } \\
\text { water }\end{array}$ & $\begin{array}{l}\text { Size } \\
(\mathrm{sq} \mathrm{m})\end{array}$ & $\underset{(\mathrm{m})}{\text { Depth }}$ & Density \\
\hline $41 L K 125$ & 1 & $2 / 3$ & STT & 166 & $\mathrm{SCL}$ & 4 & 1 & 6000 & 0.3 & 1 \\
\hline 41LK126 & 1 & 4 & UPL & 200 & SLM & 4 & 3 & 3150 & 0.3 & 2 \\
\hline 41LK127 & 1 & $2 / 3$ & UPL & 196 & LCG & 3 & 3 & 11,000 & 0.5 & 1 \\
\hline $41 L K 128$ & 1 & 3 & RTE & 180 & LCG & 3 & 1 & 350,000 & 0.5 & 2 \\
\hline 41LK1 29 & 1 & 3 & RTE & 210 & LCG & 3 & 2 & 16,000 & 0.2 & 1 \\
\hline 41LKI30 & 1 & $3 / 4$ & STF & 200 & LCG & 4 & 1 & 7500 & 0.2 & 2 \\
\hline 41LK131 & 1 & 3 & STF & 190 & LCG & 4 & 1 & 14,400 & 0.3 & 1 \\
\hline 41LK132 & 1 & $2 / 3$ & STT & 170 & SLM & 4 & 2 & 4000 & 1.0 & 1 \\
\hline 41LK133 & 1 & 3 & STT & 210 & LCG & 4 & 2 & 6750 & 0.3 & 3 \\
\hline 41LK134 & 1 & 3 & STT & 180 & LCG & 4 & 2 & 3750 & 0.5 & 1 \\
\hline 41LK135 & 1 & $2 / 4$ & STT & 230 & LCG & 4 & 2 & 3000 & 0.3 & 1 \\
\hline $41 \mathrm{LK} 136$ & 1 & 3 & STW & 190 & LCG & 4 & $2^{\prime}$ & 3825 & 0.3 & 1 \\
\hline
\end{tabular}


TABLE 4. (continued)

\begin{tabular}{|c|c|c|c|c|c|c|c|c|c|c|}
\hline $\begin{array}{l}\text { Site } \\
\text { Number }\end{array}$ & $\begin{array}{l}\text { Survey } \\
\text { Unit }\end{array}$ & $\begin{array}{l}\text { Veg. } \\
\text { Assoc. }\end{array}$ & Topography & $\begin{array}{l}\text { Elev. } \\
\text { (ft) }\end{array}$ & Soil & $\begin{array}{l}\text { Distance } \\
\text { from } \\
\text { permanent } \\
\text { water } \\
\end{array}$ & $\begin{array}{l}\text { Distance } \\
\text { from } \\
\text { seasonal } \\
\text { water } \\
\end{array}$ & $\begin{array}{l}\text { Size } \\
\text { ( sq } \mathrm{m})\end{array}$ & $\begin{array}{l}\text { Depth } \\
(\mathrm{m})\end{array}$ & Density \\
\hline $41 L K 137$ & 1 & 3 & STF & 230 & SLM & 4 & 2 & 7500 & 0.2 & 1 \\
\hline 41 LK138 & 1 & $4 / 5$ & STF & 270 & CSL & 4 & 2 & 400 & 0.5 & 1 \\
\hline 41LK139 & 1 & 5 & UPL & 270 & SLM & 4 & 3 & 120,000 & 0.3 & 1 \\
\hline $41 L K 140$ & 1 & 5 & UPL & 253 & SLM & 4 & 3 & $750^{\circ}$ & 0.2 & 3 \\
\hline 41LK141 & 1 & 3 & STF & 230 & $\mathrm{SCL}$ & 4 & 2 & 3200 & .05 & 1 \\
\hline $41 L K 142$ & 1 & 3 & STT & 230 & SLM & 4 & 2 & 9200 & 1.0 & 1 \\
\hline 41LKT43 & 1 & 3 & STT & 170 & $\mathrm{SCL}$ & 4 & 2 & 6000 & 0.5 & 1 \\
\hline $41 L K 144$ & 1 & 3 & STW & 240 & LCG & 4 & 3 & 6000 & 0.5 & 2 \\
\hline $41 L K 145$ & 1 & 5 & STT & 230 & $\mathrm{SCL}$ & 4 & 2 & 600 & 0.2 & 1 \\
\hline 41LK146 & 1 & 2 & STT & 210 & $\mathrm{SCL}$ & 4 & 2 & 675 & 0.2 & 1 \\
\hline $41 \mathrm{LK} 147$ & 1 & $2 / 3$ & STT & 220 & LCG & 4 & 2 & 7500 & 1.0 & 1 \\
\hline 41LK148 & 1 & 2 & STF & 100 & $\mathrm{SCL}$ & 4 & 2 & 3750 & 0.5 & 1 \\
\hline 41LK149 & 1 & 2 & STF & 210 & $\mathrm{SCL}$ & 4 & 2 & 8000 & 1.0 & 1 \\
\hline $47 L K 150$ & 1 & 3 & STW & 230 & $\mathrm{SCL}$ & 4 & 2 & 225 & 0.5 & 2 \\
\hline
\end{tabular}


TABLE 4. (continued)

\begin{tabular}{|c|c|c|c|c|c|c|c|c|c|c|}
\hline $\begin{array}{l}\text { Site } \\
\text { Number }\end{array}$ & $\begin{array}{l}\text { Survey } \\
\text { Unit }\end{array}$ & $\begin{array}{l}\text { Veg. } \\
\text { Assoc. }\end{array}$ & Topography & $\begin{array}{l}\text { Elev. } \\
(\mathrm{ft})\end{array}$ & Soil & $\begin{array}{l}\text { Dis tance } \\
\text { from } \\
\text { permanent } \\
\text { water }\end{array}$ & $\begin{array}{l}\text { Distance } \\
\text { from } \\
\text { seasonal } \\
\text { water }\end{array}$ & $\begin{array}{l}\text { Size } \\
(\mathrm{sq} \mathrm{m})\end{array}$ & $\underset{(m)}{\text { Depth }}$ & Density \\
\hline 41LK151 & 1 & 5 & UPL & 240 & $\mathrm{SCL}$ & 4 & 3 & 6600 & 0.3 & 1 \\
\hline 41LK152 & 1 & 5 & UPL & 270 & CSG & 4 & 3 & 100 & 0.5 & 2 \\
\hline 41LK153 & 1 & 5 & PTW & 190 & LCG & 4 & 3 & 600 & 0.5 & 2 \\
\hline $41 L K 154$ & 1 & 3 & PTF & 180 & $\mathrm{SCL}$ & 4 & 2 & 2925 & 0.3 & 1 \\
\hline $41 L K 155$ & 1 & 3 & PTF & 180 & $\mathrm{SCL}$ & 4 & 1 & 150 & 0.5 & 1 \\
\hline 41LK156 & 1 & 5 & UPL & 253 & SLM & 4 & 3 & 42,000 & 0.2 & 1 \\
\hline $41 L K 157$ & 3 & 7 & MTW & 190 & SLM & 4 & 3 & 600 & 0.2 & 1 \\
\hline $41 L K 158$ & 3 & 6 & MTW & 200 & SLM & 4 & 3 & 15,000 & 0.3 & 1 \\
\hline $41 L K 159$ & 3 & 7 & MTW & 188 & SLM & 4 & 2 & 20,000 & 1.0 & 1 \\
\hline $41 L K 160$ & 3 & 7 & RTE & 176 & SLM & 4 & 3 & 100 & 0.2 & 1 \\
\hline $41 L K 161$ & 3 & 6 & MTW & 184 & SLM & 4 & 2 & 2100 & 0.3 & 1 \\
\hline $41 L K 162$ & 3 & 6 & RTE & 194 & SLM & 4 & 3 & 1875 & 0.3 & 1 \\
\hline 41LK163 & 3 & 7 & RTE & 175 & SLM & 4 & 2 & 2000 & 0.3 & 1 \\
\hline
\end{tabular}


TABLE 4. (continued)

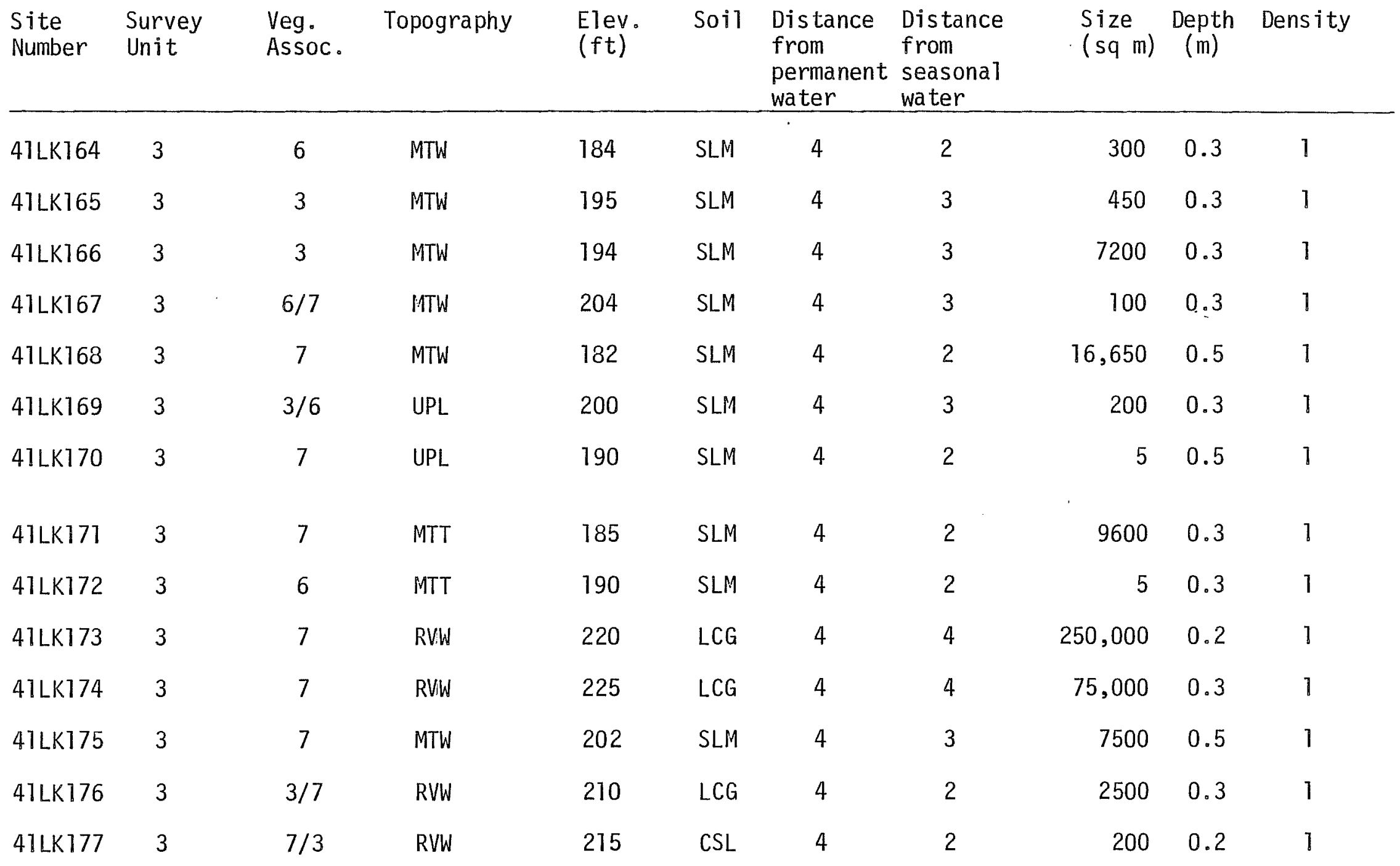


TABLE 4. (continued)

\begin{tabular}{|c|c|c|c|c|c|c|c|c|c|c|}
\hline $\begin{array}{l}\text { Site } \\
\text { Number }\end{array}$ & $\begin{array}{l}\text { Survey } \\
\text { Unit }\end{array}$ & $\begin{array}{l}\text { Veg. } \\
\text { Assoc. }\end{array}$ & Topography & $\begin{array}{l}\text { Elev. } \\
(\mathrm{ft})\end{array}$ & Soil & $\begin{array}{l}\text { Distance } \\
\text { from } \\
\text { permanent } \\
\text { water }\end{array}$ & $\begin{array}{l}\text { Distance } \\
\text { from } \\
\text { seasonal } \\
\text { water } \\
\end{array}$ & $\begin{array}{l}\text { Size } \\
(\mathrm{sq} \text { m) }\end{array}$ & $\begin{array}{l}\text { Depth } \\
(\mathrm{m})\end{array}$ & Density \\
\hline 41LK178 & 3 & 3 & RVW & 228 & LCG & 4 & 1 & 8100 & 0.2 & 1 \\
\hline $41 L K 179$ & 3 & 7 & RVW & 208 & $\mathrm{CSG}$ & 4 & 2 & 500 & 0.2 & 1 \\
\hline 41LK180 & 3 & $3 / 7$ & RVW & 228 & SLG & 4 & 3 & 7800 & 0.2 & 1 \\
\hline 41LKI81 & 3 & $3 / 7$ & RVW & 218 & CSL & 4 & 1 & 9900 & 0.2 & 1 \\
\hline $41 \mathrm{LK} / \delta 2$ & 3 & 7 & MTT & 194 & SLM & 4 & 1 & 30,000 & 0.5 & 2 \\
\hline 41LK1ठ3 & 3 & 7 & MTW & 188 & SLM & 4 & 3 & 450 & 0.3 & 1 \\
\hline 41LK184 & 3 & 7 & MTW & 184 & SLM & 4 & 2 & 17,000 & 0.3 & 1 \\
\hline 41LK1هं & 3 & 7 & MTW & 180 & SLM & 4 & 2 & 2400 & 0.3 & 2 \\
\hline 41LK1ชô & 3 & 3 & MTW & 195 & SLM & 4 & 3 & 3500 & 0.5 & 1 \\
\hline 41LK187 & 4 & 3 & MTT & 210 & SLG & 4 & 2 & 2000 & 0.2 & 1 \\
\hline 41LK1 & 4 & 3 & MTT & 200 & $\mathrm{CSG}$ & 4 & 3 & 25 & 0.2 & 1 \\
\hline $41 \mathrm{LK} 139$ & 4 & 3 & MTT & 195 & LCG & 4 & 3 & 8000 & 0.2 & 1 \\
\hline 41LK190 & 4 & 3 & MTT & 203 & SLM & 4 & 3 & 2400 & 0.2 & 1 \\
\hline
\end{tabular}


TABLE 4. (continued)

\begin{tabular}{|c|c|c|c|c|c|c|c|c|c|c|}
\hline $\begin{array}{l}\text { Site } \\
\text { Number }\end{array}$ & $\begin{array}{l}\text { Survey } \\
\text { Unit }\end{array}$ & $\begin{array}{l}\text { Veg. } \\
\text { Assoc. }\end{array}$ & Topography & $\begin{array}{l}\text { Elev. } \\
(f t)\end{array}$ & Soit & $\begin{array}{l}\text { Distance } \\
\text { from } \\
\text { permanent } \\
\text { water }\end{array}$ & $\begin{array}{l}\text { Distance } \\
\text { from } \\
\text { seasonal } \\
\text { water }\end{array}$ & $\begin{array}{l}\text { Size } \\
\text { ( sq m) }\end{array}$ & $\begin{array}{l}\text { Depth } \\
\text { (m) }\end{array}$ & Density \\
\hline 41LK191 & 4 & 3 & UPL & 218 & SLM & 4 & 3 & 5500 & 0.3 & 1 \\
\hline $41 L K 192$ & 4 & 3 & $R V W$ & 231 & SLM & 4 & 2 & 9900 & 0.2 & 1 \\
\hline $41 L K 193$ & 5 & 3 & $\mathrm{RVW}$ & 230 & $\mathrm{SCL}$ & 4 & 2 & 16,000 & 0.2 & 1 \\
\hline 41LK194 & 5 & $3 / 7$ & MTT & 208 & CSL & 4 & 3 & 30,000 & 0.5 & 2 \\
\hline 41LKT95 & 3 & 8 & RFP & 168 & $\mathrm{SCL}$ & 3 & 3 & 4000 & 1.5 & 1 \\
\hline 41LK196 & 3 & 8 & RFP & 170 & $\mathrm{SCL}$ & 3 & 3 & 9900 & 1.5 & 1 \\
\hline $41 L K 197$ & 3 & 3 & RFP & 165 & SLM & 3 & 2 & 8750 & 0.25 & 3 \\
\hline $41 L K 198$ & 3 & $6 / 7$ & RFP & 165 & SLM & 4 & 1 & 11,000 & 1.5 & 1 \\
\hline 41LK199 & 3 & 6 & RTE & 180 & SLG & 3 & 2 & 56,250 & 1.5 & 1 \\
\hline $41 \mathrm{LK} 200$ & 3 & 7 & MTF & 164 & $\mathrm{SCL}$ & 4 & 3 & 12,000 & 0.3 & 1 \\
\hline $41 L K 201$ & 3 & $1 / 8$ & RFP & 165 & SLM & 4 & 1 & 24,900 & 1.5 & 1 \\
\hline $41 L K 20^{\prime} 2$ & 3 & 1 & RFP & 160 & SLM & 1 & 1 & 500 & 0.50 & 1 \\
\hline
\end{tabular}


TABLE 4. (continued)

\begin{tabular}{|c|c|c|c|c|c|c|c|c|c|c|}
\hline $\begin{array}{l}\text { Site } \\
\text { Number }\end{array}$ & $\begin{array}{l}\text { Survey } \\
\text { Unit }\end{array}$ & $\begin{array}{l}\text { Veg. } \\
\text { Assoc. }\end{array}$ & Topography & $\begin{array}{l}\text { Elev. } \\
(f t)\end{array}$ & Soil & $\begin{array}{l}\text { Distance } \\
\text { from } \\
\text { permanent } \\
\text { water }\end{array}$ & $\begin{array}{l}\text { Distance } \\
\text { from } \\
\text { seasonal } \\
\text { water } \\
\end{array}$ & $\begin{array}{l}\text { Size } \\
\text { (sq m) }\end{array}$ & $\begin{array}{l}\text { Depth } \\
(\mathrm{m})\end{array}$ & Density \\
\hline $41 M C 196$ & 2 & 7 & PTT & 200 & SLM & 2 & 2 & 385,000 & 1.0 & 1 \\
\hline $41 M C 197$ & 2 & 3 & STT & 230 & SLM & 3 & 1 & 1400 & 1.0 & 1 \\
\hline $47 M C 198$ & 2 & 3 & STF & 220 & $\mathrm{SCL}$ & 4 & 1 & 3000 & 0.2 & 1 \\
\hline $41 M C 799$ & 2 & $2 / 3$ & STF & 220 & SLM & 4 & 1 & 900 & 1.0 & 1 \\
\hline $41 M C 200$ & 2 & 2 & STT & 220 & LCG & 3 & 1 & 20,000 & 1.0 & 1 \\
\hline $41 \mathrm{MC} 201$ & 2 & $2 / 3$ & STT & 210 & SLM & 2 & 2 & 50,000 & 1.0 & 2 \\
\hline $41 \mathrm{MC} 202$ & 2 & $2 / 3$ & STT & 215 & SLM & 3 & 2 & 60,000 & 1.0 & 2 \\
\hline $41 \mathrm{MC} 203$ & 2 & 7 & PTT & 210 & SLM & 2 & 2 & 262,500 & 1.0 & 2 \\
\hline $41 M C 2204$ & 2 & 3 & PTT & 205 & SLM & 2 & 2 & 15,750 & 1.0 & 2 \\
\hline $47 \mathrm{MC} 20 \mathrm{~S}$ & 2 & 3 & STT & 220 & SLM & 4 & 1 & 2800 & 0.3 & 2 \\
\hline $41 M C 206$ & 2 & 3 & PTT & 205 & LCG & 2 & 1 & 200 & 0.3 & 2 \\
\hline $47 M C 207$ & 2 & $2 / 3$ & PTT & 210 & SLM & 2 & 1 & 4200 & 1.0 & 1 \\
\hline $41 M C 208$ & 2 & 3 & STT & 230 & LCG & 3 & 1 & 7500 & 0.3 & 1 \\
\hline $41 M C 209$ & 2 & $2 / 3$ & STT & 230 & $\mathrm{CSG}$ & 2 & 1 & 120,000 & 0.3 & 3 \\
\hline
\end{tabular}


TABLE 4. (continued)

\begin{tabular}{|c|c|c|c|c|c|c|c|c|c|c|}
\hline $\begin{array}{l}\text { Site } \\
\text { Number }\end{array}$ & $\begin{array}{l}\text { Survey } \\
\text { Unit }\end{array}$ & $\begin{array}{l}\text { Veg. } \\
\text { Assoc. }\end{array}$ & Topography & $\begin{array}{l}\text { Elev. } \\
(f t)\end{array}$ & So il & $\begin{array}{l}\text { Distance } \\
\text { from } \\
\text { permanent } \\
\text { water }\end{array}$ & $\begin{array}{l}\text { Distance } \\
\text { from } \\
\text { seasona } 1 \\
\text { water }\end{array}$ & $\begin{array}{c}\text { Size } \\
(\mathrm{sq} \mathrm{m})\end{array}$ & $\begin{array}{c}\text { Depth } \\
\text { (m) }\end{array}$ & Density \\
\hline $41 M C 210$ & 2 & 3 & PTT & 225 & SLM & 3 & 2 & 1050 & 0.3 & 1 \\
\hline $41 \mathrm{MC} 211$ & 2 & 7 & PTT & 230 & SLM & 3 & 3 & 38,400 & 0.2 & 1 \\
\hline $47 M C 212$ & 2 & 3 & PTT & 231 & LCG & 3 & 1 & 40,000 & 0.3 & 2 \\
\hline $41 \mathrm{MC} 213$ & 2 & 3 & STT & 230 & LCG & 3 & 1 & 10,500 & 0.5 & $\therefore$ \\
\hline $47 \mathrm{MC} 214$ & 2 & 3 & UPL & 225 & LCG & 2 & 2 & 35,000 & 0.25 & 1 \\
\hline $41 M C 215$ & 2 & 3 & PTT & 210 & SLM & 2 & 1 & 7200 & 0.5 & 2 \\
\hline $41 \mathrm{MC} 216$ & 2 & $3 / 2$ & STT & 230 & LCG & 3 & 2 & 400 & 0.2 & 1 \\
\hline $41 M C^{\prime} 217$ & 2 & 3 & STT & 230 & SLM & 3 & 2 & 1200 & 0.3 & 1 \\
\hline $41 M C 218$ & 2 & $2 / 3$ & PTT & 210 & LCG & 2 & 2 & 9100 & 1.0 & 2 \\
\hline $41 M C 225$ & $\overline{0}$ & 6 & PTT & 230 & SLM & 3 & 3 & 100 & 1.0 & 1 \\
\hline $41 M C 226$ & 6 & 6 & RTE & 230 & SLG & 3 & 3 & 12,000 & 0.5 & 1 \\
\hline $41 \mathrm{NC} 227$ & 6 & 6 & RTE & 221 & SLG & 3 & 3 & 25 & 0.2 & 1 \\
\hline
\end{tabular}


TABLE 5. CULTURAL. MATERIALS AT ALL RECORDED SITES

Keys to the notations used in this table appear in Table 2. $P=$ Present; $A=$ Absent.

\begin{tabular}{|c|c|c|c|c|c|c|c|c|c|c|c|c|}
\hline $\begin{array}{l}\text { Site } \\
\text { Number }\end{array}$ & $\begin{array}{l}\mathrm{HFR} \\
/ M\end{array}$ & Flakes & $\begin{array}{c}\# \\
\text { Hearths } \\
\end{array}$ & $\begin{array}{c}\% \\
\text { HFR } \\
\end{array}$ & $\begin{array}{c}\% \\
\text { CS } \\
\end{array}$ & Cores & $\begin{array}{l}\text { Thick } \\
\text { Bifaces }\end{array}$ & $\begin{array}{l}\text { Thin } \\
\text { Bifaces }\end{array}$ & $\begin{array}{l}\text { Uni- } \\
\text { faces }\end{array}$ & $\begin{array}{c}\text { Ground } \\
\text { Stone }\end{array}$ & $\begin{array}{l}\text { Abo } \\
\text { Pottery }\end{array}$ & $\begin{array}{l}\text { Historic } \\
\text { I tems }\end{array}$ \\
\hline 4]LK31 & BTM & FLI & 2 & 30 & 70 & $P$ & $A$ & $\mathrm{P}$ & $A$ & $A$ & $A$ & $A$ \\
\hline 41LK32 & BTM & FLI & 2 & 40 & 60 & $\mathrm{P}$ & $A$ & $A$ & $A$ & $A$ & $A$ & $A$ \\
\hline 41LK118 & BTM & FLS & 4 & 60 & 40 & $\mathrm{P}$ & A & $\mathrm{P}$ & A & A & A & A \\
\hline $41 L K 119$ & BTM & FLS & 3 & 70 & 30 & $\mathrm{P}$ & $P$ & $A$ & A & $A$ & A & $A$ \\
\hline $41 \mathrm{LK} 120$ & BTM & FLS & 3 & 60 & 40 & $P$ & $P$ & $A$ & $\mathrm{P}$ & $A$ & $A$ & $A$ \\
\hline 41LK121 & BTM & FLS & 2 & 50 & 50 & $A$ & $A$ & $\mathrm{P}$ & $A$ & A & $A$ & $A$ \\
\hline $41 L K 122$ & BTM & FLI & 4 & 90 & 10 & $\mathrm{P}$ & A & $A$ & A & A & $A$ & A \\
\hline $41 L K 123$ & $x X X$ & $x X X$ & 2 & 0 & 0 & A & $A$ & $A$ & $A$ & A & $A$ & $\mathrm{P}$ \\
\hline 41 LK124 & BFT & FLS & 4 & 70 & 30 & $A$ & $A$ & $\mathrm{P}$ & A & $A$ & $A$ & $A$ \\
\hline 41LKT'25 & BFT & FLS & 3 & 80 & 20 & $\mathrm{P}$ & $A$ & $A$ & $A$ & A & $A$ & $A$ \\
\hline $41 L K 126$ & BTM & FLS & 2 & 40 & 60 & $A$ & $A$ & $P$ & $A$ & A & $A$ & $A$ \\
\hline
\end{tabular}


TABLE 5. (continued)

\begin{tabular}{|c|c|c|c|c|c|c|c|c|c|c|c|c|}
\hline $\begin{array}{l}\text { Site } \\
\text { Number }\end{array}$ & $\begin{array}{l}H F R \\
/ M\end{array}$ & Flakes & $\begin{array}{c}\# \\
\text { Hearths }\end{array}$ & $\begin{array}{c}\% \\
\mathrm{HFR}\end{array}$ & $\begin{array}{l}\% \\
\text { CS }\end{array}$ & Cores & $\begin{array}{l}\text { Thick } \\
\text { Bifaces }\end{array}$ & $\begin{array}{l}\text { Thin } \\
\text { Bifaces }\end{array}$ & $\begin{array}{l}\text { Uni- } \\
\text { faces }\end{array}$ & $\begin{array}{l}\text { Ground } \\
\text { Stone }\end{array}$ & $\begin{array}{l}\text { Abo } \\
\text { Pottery }\end{array}$ & $\begin{array}{l}\text { Historic } \\
\text { I tems }\end{array}$ \\
\hline $41 L K 127$ & BTM & FLP & 2 & 30 & 70 & $\mathrm{P}$ & $\mathrm{P}$ & A & A & A & A & A \\
\hline $41 L K 128$ & BTM & FLS & 5 & 60 & 40 & $P$ & $\mathrm{P}$ &.$P$ & A & $\mathrm{P}$ & A & A \\
\hline $41 \mathrm{LK} 129$ & BTM & FLS & 2 & 70 & 30 & $P$ & A & A & A & A & A & A \\
\hline 41LKT30 & BFT & FLP & 2 & 70 & 30 & $P$ & A & A & A & A & A & A \\
\hline 41LK131 & BFT & FLS & 2 & 70 & 30 & $P$ & A & A & A & A & A & A \\
\hline $41 \mathrm{LK} 132$ & BFT & FLI & 2 & 60 & 40 & A & A & $P$ & A & A & $A$ & A \\
\hline 41LKI 33 & BTM & FLS & 3 & 60 & 40 & $\mathrm{P}$ & $P$ & $P$ & A & $P$ & A & A \\
\hline 41LK134 & $x x x$ & FLS & 1 & 0 & 100 & $P$ & $P$ & A & A & A & A & A \\
\hline $41 L K 135$ & BFT & FLS & 2 & 70 & 30 & $\mathrm{P}$ & A & A & A & $A$ & A & A \\
\hline 41LK136 & $x x x$ & FLS & 1 & 0 & 100 & $P$ & A & A & A & $A$ & $A$ & A \\
\hline $41 \mathrm{LK} 137$ & $\mathrm{BFT}$ & FLP & 2 & 70 & 30 & $P$ & A & A & A & A & A & A \\
\hline $41 L K 138$ & BFT & FLP & 2 & 70 & 30 & $\mathrm{P}$ & A & A & A & A & A & A \\
\hline $41 L K 139$ & BFT & FLS & 4 & 80 & 20 & $\mathrm{P}$ & A & A & A & A & A & A \\
\hline
\end{tabular}


TABLE 5. (continued)

\begin{tabular}{|c|c|c|c|c|c|c|c|c|c|c|c|c|}
\hline $\begin{array}{l}\text { Site } \\
\text { Number }\end{array}$ & $\begin{array}{l}\mathrm{HFR} \\
/ \mathrm{M}\end{array}$ & Flakes & $\begin{array}{l}\text { \# } \\
\text { Hearths } \\
\end{array}$ & $\begin{array}{c}\% \\
\text { HFR } \\
\end{array}$ & $\begin{array}{l}\% \\
\text { CS }\end{array}$ & Cores & $\begin{array}{l}\text { Thick } \\
\text { Bifaces }\end{array}$ & $\begin{array}{l}\text { Thin } \\
\text { Bifaces }\end{array}$ & $\begin{array}{l}\text { Uni- } \\
\text { faces }\end{array}$ & $\begin{array}{l}\text { Ground } \\
\text { Stone }\end{array}$ & $\begin{array}{l}\text { Abo } \\
\text { Pottery }\end{array}$ & $\begin{array}{l}\text { His toric } \\
\text { I tems }\end{array}$ \\
\hline $41 L K 140$ & $x x x$ & $x x x$ & 1 & 0 & 0 & A & A & A & A & A & A & $P$ \\
\hline $41 L K 141$ & BFT & FLS & 2 & 70 & 30 & $P$ & A & $\mathrm{P}$ & A & A & A & A \\
\hline 41LK142 & BFT & FLS & 3 & 60 & 40 & $P$ & $P$ & $P$ & A & A & A & A \\
\hline 41LK143 & BTM & FLS & 2 & 70 & 30 & $P$ & $P$ & A & A & A & A & A \\
\hline $41 \mathrm{LK} 144$ & BTM & FLS & 3 & 90 & 10 & $\mathrm{P}$ & A & A & A & A & A & A \\
\hline $41 L K 145$ & BFT & FLS & 2 & 90 & 10 & A & A & A & A & A & A & A \\
\hline 41LK146 & $\mathrm{BFT}$ & FLP & 2 & 80 & 20 & A & $P$ & A & A & A & A & A \\
\hline 41LK147 & BFT & FLS & 2 & 40 & 60 & $P$ & A & A & A & A & A & A \\
\hline 41LK148 & BFT & FIS & 2 & 40 & 60 & $P$ & A & A & A & A & A & A \\
\hline 41LK149 & BFT & FLS & 2 & 50 & 50 & A & $\mathrm{P}$ & A & P & A & A & A \\
\hline 41LK150 & BFT & FLS & 2 & 40 & 60 & $P$ & $P$ & $P$ & A & A & A & A \\
\hline 41LK151 & BFT & FLS & 2 & 60 & 40 & $\mathrm{P}$ & A & A & A & A & A & A \\
\hline 41LK152 & BFT & FLP & 2 & 10 & 90 & $P$ & P & A & A & A & A & A \\
\hline
\end{tabular}


TABLE 5. (continued)

\begin{tabular}{|c|c|c|c|c|c|c|c|c|c|c|c|c|}
\hline $\begin{array}{l}\text { Site } \\
\text { Number }\end{array}$ & $\begin{array}{l}\text { HFR } \\
/ M\end{array}$ & Flakes & $\begin{array}{c}\stackrel{n}{\#} \\
\text { Hearths }\end{array}$ & $\begin{array}{c}\% \\
\text { HFR }\end{array}$ & $\begin{array}{c}\% \\
\mathrm{CS} \\
\end{array}$ & Cores & $\begin{array}{l}\text { Thick } \\
\text { Bifaces }\end{array}$ & $\begin{array}{l}\text { Thin } \\
\text { Bifaces }\end{array}$ & $\begin{array}{l}\text { Uni- } \\
\text { faces }\end{array}$ & $\begin{array}{l}\text { Ground } \\
\text { Stone }\end{array}$ & $\begin{array}{l}\text { Abo } \\
\text { Pottery }\end{array}$ & $\begin{array}{l}\text { Historic } \\
\text { I tems }\end{array}$ \\
\hline $41 L K 153$ & BFT & FLP & 2 & 10 & 90 & $P$ & $\mathrm{P}$ & $A$ & $A$ & $A$ & A & $A$ \\
\hline $41 L K 154$ & $\mathrm{BFT}$ & FLS & 2 & 90 & 10 & $A$ & A & $A$ & $A$ & A & $A$ & A \\
\hline $41 L K 155$ & BFT & FLS & 2 & 80 & 20 & $A$ & $A$ & $A$ & A & A & $A$ & A \\
\hline $41 L K 156$ & BFT & FLS & 3 & 70 & 30 & $\mathrm{P}$ & $A$ & $A$ & $A$ & $A$ & $A$ & $A$ \\
\hline $41 L K 157$ & BFT & FLI & 2 & 80 & 20 & $\mathrm{P}$ & $A$ & A & $A$ & $A$ & $A$ & $A$ \\
\hline $41 L K 158$ & $\mathrm{BFT}$ & FLI & 3 & 70 & 30 & $P$ & $A$ & $P$ & $A$ & $A$ & A & $A$ \\
\hline $41 L K 159$ & BTM & FLS & 3 & 80 & 20 & $P$ & $A$ & $P$ & $A$ & $A$ & $A$ & $P$ \\
\hline $41 L K 160$ & $\mathrm{BFT}$ & FLS & 2 & 90 & 10 & $A$ & $A$ & ${ }^{n} \mathrm{~A}$ & A & $A$ & A & $A$ \\
\hline 41LK161 & $\mathrm{BFT}$ & FLS & 2 & 80 & 20 & $P$ & $A$ & A & $A$ & $A$ & $A$ & $A$ \\
\hline $41 L K 162$ & $\mathrm{BFT}$ & FLI & 2 & 90 & 10 & $P$ & $A$ & $A$ & $A$ & $A$ & $A$ & $A$ \\
\hline $41 L K 163$ & $B F L$ & FLI & 2 & 50 & 50 & $A$ & $A$ & $A$ & $A$ & $A$ & $A$ & $\mathrm{P}$ \\
\hline 41LK 164 & $\mathrm{BFT}$ & FLS & 2 & 90 & 10 & $A$ & $A$ & $A$ & $A$ & $A$ & $A$ & $A$ \\
\hline $41 L K 165$ & $\mathrm{BFT}$ & FLI & 2 & 70 & 30 & $A$ & $A$ & $A$ & $P$ & $A$ & $A$ & $A$ \\
\hline $41 \mathrm{LK} 166$ & BFT & FLI & 2 & 70 & 30 & $A$ & $A$ & A & $P$ & A & $A$ & $A$ \\
\hline
\end{tabular}


TABLE 5. (continued)

\begin{tabular}{|c|c|c|c|c|c|c|c|c|c|c|c|c|}
\hline $\begin{array}{l}\text { Site } \\
\text { Number }\end{array}$ & $\begin{array}{l}\mathrm{HFR} \\
/ \mathrm{M} \\
\end{array}$ & Flakes & $\begin{array}{c}\# \\
\text { Hearths } \\
\end{array}$ & $\begin{array}{c}\% \\
\text { HFR }\end{array}$ & $\begin{array}{l}\% \\
\mathrm{CS} \\
\end{array}$ & Cores & $\begin{array}{l}\text { Thick } \\
\text { Bifaces }\end{array}$ & $\begin{array}{l}\text { Thin } \\
\text { Bifaces }\end{array}$ & $\begin{array}{l}\text { Uni- } \\
\text { faces }\end{array}$ & $\begin{array}{l}\text { Ground } \\
\text { Stone }\end{array}$ & $\begin{array}{l}\text { Abo } \\
\text { Pottery }\end{array}$ & $\begin{array}{l}\text { Historic } \\
\text { Items }\end{array}$ \\
\hline 41LK167 & BFT & FLI & 2 & 90 & 10 & $P$ & $A$ & $P$ & $A$ & $A$ & $A$ & $A$ \\
\hline 41LK168 & BFT & FLI & 2 & 70 & 30 & $\mathrm{P}$ & $A$ & $A$ & $A$ & $A$ & $A$ & $\mathrm{P}$ \\
\hline 41LK169 & $B F L$ & FLI & 2 & 90 & 10 & $A$ & $A$ & A & $A$ & $A$ & $A$ & A \\
\hline 41LK170 & BFL & FLI & 2 & 70 & 30 & A & $A$ & A & A & $A$ & $A$ & $A$ \\
\hline $41 L K 171$ & BLM & FLS & 3 & 80 & 20 & $\mathrm{P}$ & $A$ & $P$ & $A$ & $A$ & $A$ & $A$ \\
\hline 41LK172 & $\mathrm{BFT}$ & FLS & 2 & 90 & 10 & $A$ & $A$ & $A$ & $A$ & $A$ & $A$ & $A$ \\
\hline $41 L K 173$ & $\mathrm{BFT}$ & FLS & 5 & 80 & 20 & $P$ & $\mathrm{P}$ & $\mathrm{P}$ & $A$ & $A$ & $A$ & $A$ \\
\hline 41 LK174 & $\mathrm{BFT}$ & FLS & 5 & 80 & 20 & $\mathrm{P}$ & $P$ & $\mathrm{P}$ & $A$ & $A$ & $A$ & $A$ \\
\hline 41LK175 & $\mathrm{BFT}$ & FLI & 3 & 60 & 40 & $P$ & $\mathrm{P}$ & $A$ & $A$ & $A$ & $A$ & $A$ \\
\hline $41 L K 176$ & BFT & FLI & 4 & 70 & 30 & $\mathrm{P}$ & $P$ & $\mathrm{P}$ & $\mathrm{P}$ & $\mathrm{P}$ & $\mathrm{P}$ & $A$ \\
\hline $41 L K 177$ & BFT & FLP & 2 & 70 & 30 & $\mathrm{P}$ & $A$ & A & $A$ & A & $A$ & A \\
\hline $41 \mathrm{LK} \| .78$ & BFT & FLI & 2 & 80 & 20 & $\mathrm{P}$ & $P$ & $A$ & $A$ & $\mathrm{P}$ & $A$ & $A$ \\
\hline 41LK179 & BFT & FLS & 2 & 70 & 30 & $P$ & $P$ & $A$ & $A$ & $A$ & $A$ & $A$ \\
\hline
\end{tabular}


TABLE 5. (continued)

\begin{tabular}{|c|c|c|c|c|c|c|c|c|c|c|c|c|}
\hline $\begin{array}{l}\text { Site } \\
\text { Number }\end{array}$ & $\begin{array}{l}\mathrm{HFR} \\
\mathrm{MM}\end{array}$ & Flakes & $\begin{array}{c}\# \\
\text { Hearths } \\
\end{array}$ & $\begin{array}{c}\% \\
\text { HFR } \\
\end{array}$ & $\begin{array}{l}\% \\
\text { CS } \\
\end{array}$ & Cores & $\begin{array}{c}\text { Thick } \\
\text { Bifaces }\end{array}$ & $\begin{array}{c}\text { Thin } \\
\text { Bifaces }\end{array}$ & $\begin{array}{r}\text { Uni- } \\
\text { faces }\end{array}$ & $\begin{array}{l}\text { Ground } \\
\text { Stone }\end{array}$ & $\begin{array}{c}\text { Abo } \\
\text { Pottery }\end{array}$ & $\begin{array}{r}\text { Histor } \\
\text { It tems }\end{array}$ \\
\hline 41LK180 & BLM & FLI & 2 & 80 & 20 & P & $\mathrm{P}$ & A & A & $\mathrm{P}$ & A & A \\
\hline 41LK181 & BFT & FLS & 2 & 80 & 20 & A & $P$ & P: & A & $\mathrm{P}$ & A & A \\
\hline 41LK132 & BFT & FLS & 4 & 50 & 50 & $P$ & $P$ & $P$ & $P$ & $P$ & A & A \\
\hline 41LK183 & BFT & FLI & 2 & 60 & 40 & $\mathrm{P}$ & A & $A$ & $P$ & A & A & A \\
\hline 41LK134 & BFT & FLI & 3 & 60 & 40 & $P$ & A & $A$ & A & A & A & A \\
\hline 41LK185 & BFT & FLS & 2 & 50 & 50 & $P$ & A & P & A & P & A & A \\
\hline 41 LK186 & BFT & FLS & 2 & 50 & 50 & $\mathrm{P}$ & A & P & A & A & $A$ & A \\
\hline 41LK187 & BFT & FLS & 2 & 30 & 70 & $P$ & $\mathrm{P}$ & A & A & A & A & A \\
\hline 41LK180 & $\mathrm{BFT}$ & FLI & 1 & 60 & 40 & A & A & A & A & A & A & A \\
\hline 41LK189 & BFT & FLI & 2 & 70 & 30 & $P$ & A & A & A & A & A & A \\
\hline 41LK190 & BFT & FLI & 2 & 40 & 60 & A & A & A & A & A & A & A \\
\hline 41LK191 & BTM & FLI & 3 & 50 & 50 & A & A & P & P & A & A & A \\
\hline 41LK192 & $B F L$ & FL I & 3 & 60 & 40 & $P$ & $P$ & $\mathrm{P}$ & $P$ & $\mathrm{P}$ & A & A \\
\hline 41LK193 & BFT & FIS & 5 & 70 & 30 & $\mathrm{P}$ & A & $\mathrm{P}$ & A & $\mathrm{P}$ & A & A \\
\hline
\end{tabular}


TABLE 5. (continued)

\begin{tabular}{|c|c|c|c|c|c|c|c|c|c|c|c|c|}
\hline $\begin{array}{l}\text { Site } \\
\text { Number }\end{array}$ & $\begin{array}{l}\mathrm{HFR} \\
/ \mathrm{M}\end{array}$ & Flakes & $\begin{array}{c}\# \\
\text { Hearths } \\
\end{array}$ & $\begin{array}{c}\% \\
\text { HFR } \\
\end{array}$ & $\begin{array}{c}\% \\
\mathrm{CS} \\
\end{array}$ & Cores & $\begin{array}{c}\text { Thick } \\
\text { B ifaces }\end{array}$ & $\begin{array}{c}\text { Thin } \\
\text { Bifaces }\end{array}$ & $\begin{array}{r}\text { Uni- } \\
\text { faces }\end{array}$ & $\begin{array}{r}\text { Ground } \\
\text { Stone }\end{array}$ & $\begin{array}{c}\text { Abo } \\
\text { Pottery }\end{array}$ & $\begin{array}{c}\text { Historic } \\
\text { Items }\end{array}$ \\
\hline 41 LK194 & BLM & FLS & 3 & 70 & 30 & $\mathrm{P}$ & A & $P$ & A & A & A & $A$ \\
\hline 41LK195 & BTM & FLI & 2 & 70 & 30 & $A$ & A & $P$ & $A$ & $A$ & A & A \\
\hline 41LK196 & BFT & FLI & 2 & 90 & 10 & $P$ & A & $P$ & A & $A$ & A & $A$ \\
\hline $41 L K 197$ & $x X X$ & $x x X$ & 1 & 0 & 0 & $A$ & A & $A$ & $A$ & $A$ & A & $P$ \\
\hline 41LK198̈ & BTM & FLI & 3 & 40 & 60 & $P$ & A & $P$ & A & A & A & A \\
\hline 41LK199 & BFT & FLI & 2 & 40 & 60 & $\mathrm{P}$ & A & $P$ & A & A & A & $\mathrm{P}$ \\
\hline $41 L K 200$ & $\mathrm{BFT}$ & FLI & 2 & 90 & 10 & $P$ & A & A & $A$ & $A$ & A & $A$ \\
\hline 41LK201 & BTM & FLI & 4 & 40 & 60 & $P$ & A & $\mathrm{P}$ & A & $\mathrm{P}$ & $A$ & $A$ \\
\hline 41LK202 & $X X X$ & $X X X$ & 1 & 0 & 0 & A & A & A & A & A & A & $\mathrm{P}$ \\
\hline $41 M C 196$ & BTM & FLI & 5 & 60 & 40 & $P$ & $P$ & $\mathrm{P}$ & $P$ & $\mathrm{P}$ & A & $A$ \\
\hline 41 MC197 & BFS & FLS & 2 & 60 & 40 & $P$ & A & A & A & A & A & A \\
\hline $41 M C 1903$ & BFT & FLS & 2 & 70 & 30 & A & A & A & A & $A$ & A & $A$ \\
\hline $41 M C 199$ & BFT & FLP & 2 & 60 & 40 & $\mathrm{P}$ & $A$ & $A$ & $A$ & $A$ & $A$ & $A$ \\
\hline
\end{tabular}


TABLE 5. (continued)

\begin{tabular}{|c|c|c|c|c|c|c|c|c|c|c|c|c|}
\hline $\begin{array}{l}\text { Site } \\
\text { Number }\end{array}$ & $\begin{array}{l}\mathrm{HFR} \\
\mathrm{MM}\end{array}$ & Flakes & $\begin{array}{c}\# \\
\text { Hearths } \\
\end{array}$ & $\begin{array}{c}\% \\
\text { HFR } \\
\end{array}$ & $\begin{array}{l}\% \\
\text { CS }\end{array}$ & Cores & $\begin{array}{c}\text { Thick } \\
\text { Bifaces } \\
\end{array}$ & $\begin{array}{c}\text { Thin } \\
\text { Bifaces }\end{array}$ & $\begin{array}{r}\text { Uni- } \\
\text { faces }\end{array}$ & $\begin{array}{l}\text { Ground } \\
\text { Stone }\end{array}$ & $\begin{array}{c}\text { Abo } \\
\text { Pottery }\end{array}$ & $\begin{array}{r}\text { Histor } \\
\text { Items }\end{array}$ \\
\hline 41 MC200 & BFT & FLS & 3 & 70 & 30 & $P$ & A & A & A & A & A & A \\
\hline $41 M C 201$ & BFS & FLI & 5 & 80 & 20 & $P$ & A & A & A & A & $A$ & A \\
\hline $41 M C 202$ & BFT & FLI & 3 & 70 & 30 & $\mathrm{P}$ & A & A & A & A & A & A \\
\hline 41:MC203 & BFT & FLI & 5 & 70 & 30 & $P$ & $P$ & $\mathrm{P}$ & $P$ & $P$ & A & A \\
\hline $41 M C 204$ & BFT & FLI & 4 & 80 & 20 & $\mathrm{P}$ & A & $\mathrm{P}$ & A & A & A & $\cdots$ \\
\hline $47 M C 205$ & BFT & FLS & 2 & 40 & 60 & $P$ & $P$ & $P$ & $A$ & A & $A$ & A \\
\hline $41 M C 206$ & BTM & FLS & 2 & 70 & 30 & $\mathrm{P}$ & A & A & A & $P$ & A & A \\
\hline 47 IMC207 & $\mathrm{BFT}$ & FLS & 3 & 60 & 40 & $\mathrm{P}$ & A & A & A & $A$ & A & A \\
\hline 47MC208 & BFT & FLI & 3 & 80 & 20 & $P$ & $A$ & A & A & A & A & N \\
\hline $47 M C 209$ & BSM & FLI & 5 & 90 & 10 & $\mathrm{P}$ & $\mathrm{P}$ & $\mathrm{P}$ & $P$ & $P$ & A & \\
\hline $47 M C 210$ & BFT & FLS & 2 & 70 & 30 & $P$ & A & A & A & A & A & \\
\hline $47 M C 211$ & BFS & FLS & 3 & 70 & 30 & $P$ & P & A & A & A & $A$ & \\
\hline $47 M C 212$ & BFT & FLS & 5 & 80 & 20 & $\mathrm{P}$ & $P$ & $P$ & $P$ & A & A & \\
\hline $47 M C 213$ & BFT & FLS & 3 & 70 & 30 & $P$ & $P$ & $P$ & A & $A$ & $A$ & \\
\hline
\end{tabular}


TABLE 5. (continued)

\begin{tabular}{|c|c|c|c|c|c|c|c|c|c|c|c|c|}
\hline $\begin{array}{l}\text { Site } \\
\text { Number }\end{array}$ & $\begin{array}{l}\text { HFR } \\
\text { /M }\end{array}$ & Flakes & $\begin{array}{c}\text { \# } \\
\text { Hearths }\end{array}$ & $\begin{array}{c}\% \\
H F R \\
H\end{array}$ & $\begin{array}{l}\% \\
\text { CS } \\
\end{array}$ & Cores & $\begin{array}{c}\text { Thick } \\
\text { Bifaces }\end{array}$ & $\begin{array}{l}\text { Thin } \\
\text { Bifaces }\end{array}$ & $\begin{array}{l}\text { Uni- } \\
\text { faces }\end{array}$ & $\begin{array}{l}\text { Ground } \\
\text { Stone }\end{array}$ & $\begin{array}{c}\text { Abo } \\
\text { Pottery }\end{array}$ & $\begin{array}{l}\text { His toric } \\
\text { I tems }\end{array}$ \\
\hline $41 \mathrm{MC} 214$ & $X X X$ & $X X X$ & 1 & 0 & 0 & A & A & A & A & A & A & $\mathrm{P}$ \\
\hline $41 M C 215$ & BFS & FLS & 4 & 80 & 20 & $\mathrm{P}$ & P & $P$ & A & A & A & A \\
\hline $41 M C 216$ & BFT & FLS & 2 & 80 & 20 & $P$ & A & A & A & A & A & A \\
\hline $41 M C 217$ & BFT & FLS & 2 & 90 & 10 & $P$ & A & A & A & A & A & A \\
\hline $41 \mathrm{MC} 218$ & BFS & FLI & 3 & 60 & 40 & $\mathrm{P}$ & $P$ & $P$ & A & $P$ & A & A \\
\hline 41MC225 & BFS & FLI & 3 & 70 & 30 & A & A & A & A & $P$ & A & A \\
\hline $41 M C 226$ & BFT & FLI & 2 & 30 & 70 & $\mathrm{P}$ & $P$ & $P$ & A & A & A & A \\
\hline $41 M C 227$ & BFT & FLI & 2 & 90 & 10 & $P$ & A & A & A & $P$ & A & A \\
\hline
\end{tabular}




\begin{tabular}{|c|c|c|c|c|}
\hline Number & Topography & $\begin{array}{l}\text { Associated } \\
\text { Sites } \\
\end{array}$ & Size & Description \\
\hline 1 & gravel ridge & $41 L K 119$ & $\begin{array}{l}450 x \\
280 \mathrm{~m}\end{array}$ & cortex flakes; cores \\
\hline 2 & $\begin{array}{l}\text { ridge ends and } \\
\text { slopes }\end{array}$ & $41 L K 129$ & $\begin{array}{l}575 \times \\
250 \mathrm{~m}\end{array}$ & heat-fractured rock; chipped stone debitage \\
\hline 3 & $\begin{array}{l}\text { gravel covered } \\
\text { ridges }\end{array}$ & $41 L K 130$ & $\begin{array}{l}675 \times \\
250 \mathrm{~m}\end{array}$ & quarry debris incl. cores, cortex flakes \\
\hline 4 & $\begin{array}{l}\text { gravel ridge tops } \\
\text { and slopes }\end{array}$ & $\begin{array}{l}41 L K 140 \\
41 L K 156\end{array}$ & $\begin{array}{r}2750 \times \\
325 \mathrm{~m}\end{array}$ & very thin scatter; heat-fractured rock \\
\hline 5 & $\begin{array}{l}\text { ridge tops and } \\
\text { slopes }\end{array}$ & $\begin{array}{l}41 L K 151 \\
41 L K 152\end{array}$ & $\begin{array}{l}950 \times \\
450 \mathrm{~m}\end{array}$ & $\begin{array}{l}\text { quarry debris incl. tested cores and } \\
\text { cortex flakes }\end{array}$ \\
\hline 6 & $\begin{array}{l}\text { gravel covered } \\
\text { ridge slopes }\end{array}$ & $41 \mathrm{MC} 196$ & $\begin{array}{l}280 x \\
200 \mathrm{~m}\end{array}$ & chipped stone quarry debris \\
\hline 7 & $\begin{array}{l}\text { gravel covered ridge } \\
\text { slopes }\end{array}$ & $\begin{array}{l}41 \mathrm{MC} 196 \\
\operatorname{LDS} 6\end{array}$ & $\begin{array}{l}625 \times \\
125 \mathrm{~m}\end{array}$ & chipped stone quarry debris \\
\hline 8 & $\begin{array}{l}\text { north slope of gravel } \\
\text { covered ridge over- } \\
\text { looking secondary } \\
\text { tributary }\end{array}$ & $47 M C 198$ & $\begin{array}{r}1000 \mathrm{x} \\
150 \mathrm{~m}\end{array}$ & chipped stone quarry debris \\
\hline 9 & $\begin{array}{l}\text { south slope as in } \\
\text { LDS } 8\end{array}$ & $41 M C 198$ & $\begin{array}{l}500 \mathrm{x} \\
100 \mathrm{~m}\end{array}$ & chipped stone quarry debris \\
\hline
\end{tabular}


TABLE 6. (continued)

\begin{tabular}{|c|c|c|c|c|}
\hline Number & Topography & $\begin{array}{l}\text { Associated } \\
\text { Sites }\end{array}$ & Size & Description \\
\hline 10 & $\begin{array}{l}\text { along secondary tri- } \\
\text { butary }\end{array}$ & $41 \mathrm{MC} 197$ & $\begin{array}{r}175 \times \\
75 \mathrm{~m}\end{array}$ & $\begin{array}{l}\text { heat-fractured rock; chipped stone } \\
\text { debitage }\end{array}$ \\
\hline 11 & $\begin{array}{l}\text { gravel bar-like feature } \\
\text { in floodplain of Opossum } \\
\text { creek }\end{array}$ & $\begin{array}{l}41 \mathrm{MC} 196 \\
41 \mathrm{MC} 206\end{array}$ & $\begin{array}{l}475 \times \\
200 \mathrm{~m}\end{array}$ & chipped stone quarry debris \\
\hline 12 & $\begin{array}{l}\text { eroded secondary tri- } \\
\text { butary terrace }\end{array}$ & $41 M C 210$ & $\begin{array}{l}125 \mathrm{x} \\
125 \mathrm{~m}\end{array}$ & $\begin{array}{l}\text { heat-fractured sandstone; a few pieces } \\
\text { of chipped stone debitage }\end{array}$ \\
\hline 13 & $\begin{array}{l}\text { gravel ridge top and } \\
\text { slopes }\end{array}$ & $47 M C 214$ & $\begin{array}{l}275 \mathrm{x} \\
250 \mathrm{~m}\end{array}$ & chipped stone quarry debris \\
\hline 14 & $\begin{array}{l}\text { gravel ridge top and } \\
\text { slopes overlooking } \\
\text { Opossum creek and a } \\
\text { secondary tributary. }\end{array}$ & $41 M C 206$ & $\begin{array}{l}700 x \\
275 \mathrm{~m}\end{array}$ & $\begin{array}{l}\text { chipped stone quarry debris; some heat- } \\
\text { fractured rock }\end{array}$ \\
\hline 15 & $\begin{array}{l}\text { cleared field of } \\
\text { bermuda grass }\end{array}$ & $41 L K 158$ & $\begin{array}{l}475 \mathrm{x} \\
250 \mathrm{~m}\end{array}$ & heat-fractured rock; chipped stone debitage \\
\hline 16 & top of a low ridge & $\begin{array}{l}41 L K 163 \\
41 L K 165\end{array}$ & $\begin{array}{l}250 \times \\
250 \mathrm{~m}\end{array}$ & $\begin{array}{l}\text { heat-fractured chert; some chipped stone } \\
\text { debitage }\end{array}$ \\
\hline 17 & $\begin{array}{l}\text { cleared area on a low } \\
\text { ridge top }\end{array}$ & $41 L K 167$ & $\begin{array}{r}275 \times \\
75 \mathrm{~m}\end{array}$ & heat-fractured rock; chipped stone debris \\
\hline 18 & bermuda grass pasture & $41 L K 169$ & $\begin{array}{l}900 \times \\
425 \mathrm{~m}\end{array}$ & $\begin{array}{l}\text { heat-fractured chert and caliche; chipped } \\
\text { stone debris; core; thick biface }\end{array}$ \\
\hline
\end{tabular}




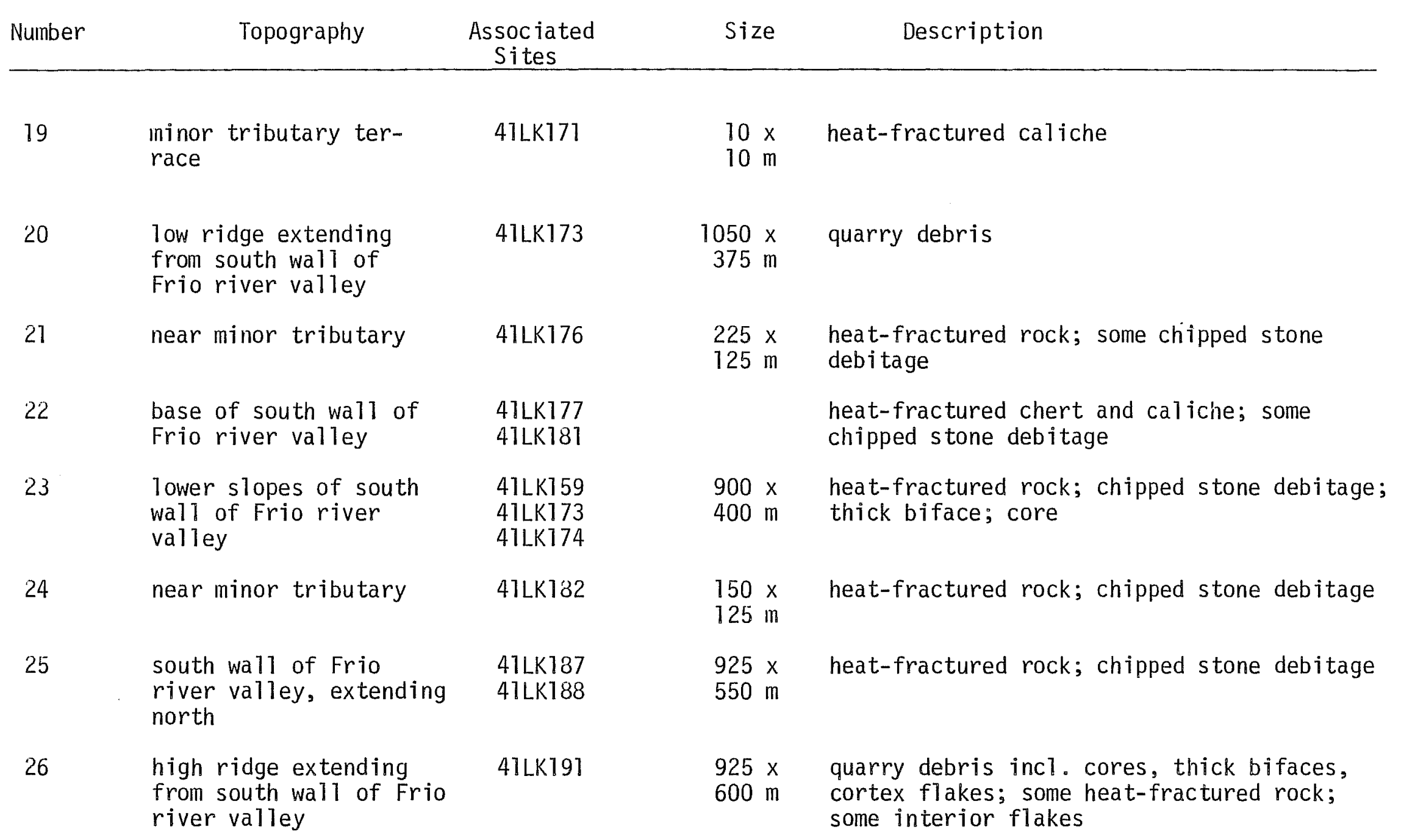


TABLE 6. (continued)

\begin{tabular}{|c|c|c|c|c|}
\hline Number & Topography & $\begin{array}{l}\text { Associated } \\
\text { Sites } \\
\end{array}$ & Size & Description \\
\hline 27 & $\begin{array}{l}\text { south wall of Frio river } \\
\text { valley }\end{array}$ & & $\begin{array}{l}850 \times \\
450 \mathrm{~m}\end{array}$ & quarry debris; some heat-fractured rock \\
\hline 28 & $\begin{array}{l}\text { south wall of Frio river } \\
\text { valley }\end{array}$ & $41 L K 193$ & $\begin{array}{l}150 \times \\
100 \mathrm{~m}\end{array}$ & quarry debris; some heat-fractured rock \\
\hline 29 & near minor tributary & $41 L K 193$ & $\begin{array}{l}75 \times \\
75 \mathrm{~m}\end{array}$ & heat-fractured rock; chipped stone debitage \\
\hline 30 & along minor tributary & $41 L K 193$ & $\begin{array}{l}175 \times \\
125 \mathrm{~m}\end{array}$ & heat-fractured rock; chipped stone debitage \\
\hline 31 & $\begin{array}{l}\text { along minor tributary, } \\
\text { below south wall of } \\
\text { Frio river valley }\end{array}$ & $\begin{array}{l}41 L K 193 \\
41 L K 194\end{array}$ & $\begin{array}{r}125 \mathrm{x} \\
75 \mathrm{~m}\end{array}$ & heat-fractured rock; chipped stone debitage \\
\hline 32 & $\begin{array}{l}\text { along and below south } \\
\text { wall of Frio river valley }\end{array}$ & $41 L K 194$ & $\begin{array}{l}400 \times \\
150 \mathrm{~m}\end{array}$ & heat-fractured rock; chipped stone debitage \\
\hline 33 & $\begin{array}{l}\text { adjacent to meander scar } \\
\text { in south part of flood- } \\
\text { plain of Frio river }\end{array}$ & $41 L K 195$ & $\begin{array}{l}500 \times \\
175 \mathrm{~m}\end{array}$ & heat-fractured chert and caliche; cores; flakes \\
\hline 34 & $\begin{array}{l}\text { adjacent to meander scar } \\
\text { in south part of flood- } \\
\text { plain of Frio river }\end{array}$ & $41 L K 196$ & $\begin{array}{l}375 \times \\
175 \mathrm{~m}\end{array}$ & heat-fractured chert and caliche; flakes; cores \\
\hline
\end{tabular}




\begin{tabular}{|c|c|c|c|c|}
\hline Number & Topography & $\begin{array}{c}\text { Associated } \\
\text { Sites } \\
\end{array}$ & Size & Description \\
\hline 35 & $\begin{array}{l}\text { south part of Frio river } \\
\text { floodplain }\end{array}$ & $\begin{array}{l}\quad 41 \text { LK } 197 \\
\text { (near } 41 \text { LK } 37 \\
\text { recorded by } \\
\text { Coastal Bend } \\
\text { A.S.) }\end{array}$ & $\begin{array}{l}625 x \\
200 \mathrm{~m}\end{array}$ & heat-fractured caliche and sandstone \\
\hline 37 & $\begin{array}{l}\text { edge of meander scar } \\
\text { in Frio river floodplain }\end{array}$ & $41 L K 159$ & $\begin{array}{l}50 x \\
40 \mathrm{~m}\end{array}$ & $\begin{array}{l}\text { heat-fractured chert; flakes; mussel shells; } \\
\text { incised sandstone }\end{array}$ \\
\hline 40 & $\begin{array}{l}\text { low ridge extending into } \\
\text { south part of Frio river } \\
\text { floodplain }\end{array}$ & $47 L K 199$ & $\begin{array}{l}300 \mathrm{x} \\
150 \mathrm{~m}\end{array}$ & heat-fractured rock; chipped stone debitage \\
\hline 41 & $\begin{array}{l}\text { gravel ridge slopes, } \\
\text { adjacent to southern part } \\
\text { of Frio river floodplain }\end{array}$ & $41 L K 200$ & $\begin{array}{l}175 \times \\
100 \mathrm{~m}\end{array}$ & quarry debris \\
\hline
\end{tabular}


TABLE 6. (continued)

\begin{tabular}{|c|c|c|c|c|}
\hline Number & Topography & $\begin{array}{l}\text { Associated } \\
\text { Sites }\end{array}$ & Size & Description \\
\hline 42 & $\begin{array}{l}\text { low gravel ridge and } \\
\text { its slopes }\end{array}$ & 41LK199 & $\begin{aligned} 350 \times \\
75 \mathrm{~m}\end{aligned}$ & $\begin{array}{l}\text { heat-fractured rock; chipped stone } \\
\text { debi tage }\end{array}$ \\
\hline 43 & $\begin{array}{l}\text { south part of Frio } \\
\text { river floodplain }\end{array}$ & 41LK201 & $\begin{array}{l}400 \mathrm{x} \\
250 \mathrm{~m}\end{array}$ & $\begin{array}{l}\text { heat-fractured rock; chipped stone; } \\
\text { mussel shell }\end{array}$ \\
\hline
\end{tabular}


TABLE 7. GENERAL CLASSIFICATION OF COLLECTED ABORIGINAL MATERIALS

I. Lithic Materials (3463 specimens)

A. Chipped Stone (1337)

1. Cores (120)

a. Tested Cores (23):

b. Unidirectional Cores (26)

c. Multidirectional, Prepared Platform Cores (58)

d. Secondary Cores (13)

2. Trimmed Artifacts (44)

a. Trimmed Cobbles (10)

b. Trimmed Flakes (21)

(1) Unifacially Trimmed (14)

(2) Bifacially Trimmed (7)

c. Trimmed Chips (13)

3. Unifacial Artifacts (7)

a. Complete Unifaces (3)

b. Incomplete Unifaces (4)

4. Bifacial Artifacts (109)

a. Thick Bifaces (49)

(1) Ovate/Ovoid (19)

(2) Rounded End (14)

(3) Beveled End (2)

(4) Round (8)

(5) Sma11 (6)

b. Thin Bifaces (41)

(1) Wide (9)

(2) Trianguloid (8)

(3) Trianguloid Beveled (5)

(4) Rectanguloid (3)

(5) Elongated (5)

(6) Concave Base (2)

(7) Rounded End (4)

(8) Pointed End (5)

c. Projectile Pointlike Bifaces (10)

(1) Dare (1)

(2) Edgewaod/Ensor (3)

(3) Gary (1)

(4) Frio (1)

(5) Pedernales (2)

(6) Angostura (1)

(7) Perdiz (1)

d. Miscellaneous Bifaces (10)

5. Debitage (1056)

a. Flakes (571)

b. Chips (457)

c. Shatter (29) 
TABLE 7. (continued)

B. Ground Stone (16)

1. Grinding Stones (4)

2. Grinding Slabs (5)

3. Incised (4)

4. Indeterminate (3)

C. Hammerstones (5)

D. Heat-Fractured Rock (2049)

E. Other Lithic Material

1. Split Cobbles (10)

2. Altered Gravels (4)

3. Petrified Wood (5)

4. Unaltered Sandstone (19)

5. Unaltered Gravels and Cobbles (18)

II. Other Materials

A. Ceramics (1)

B. Burned Clay (7)

C. Faunal Remains

1. Bone (15)

2. Mussel She11 (84)

3. Gastropod Shell (324)

D. Miscellaneous (4)

Two basic questions were asked about the soil samples: 1) Do chemical soil constituents such as $\mathrm{pH}$ and phosphorus indicate prehistoric cultural activity? (cf. Ahler 1971; Gunn and Mahula 1977) and 2) What were the depositional histories at the tested sites? Four chemical components of soils were quantified during the laboratory analyses. They were hydrogen-ion level $(\mathrm{pH})$, percentage of organic matter $(\mathrm{OM})$, percentage of calcium carbonate $\left(\mathrm{CaCO}_{3}\right)$, and the concentration (in parts per million) of total phosphate $\left(\mathrm{P}_{2} \mathrm{O}_{5}\right)$. Results are presented and discussed in the site descriptions.

Lithic manufacturing processes were suggested. Observations resulting from microscopic study of edge damage, using (Ahler 1971) and Tringham et al. (1974) as guides, are presented. Readers should consult Tringham et al. (1974) for interpretations of the edge damage and use-wear data presented in this report. In order to test the comparability of published edge damage descriptions to our project materials, we conducted some brief experiments. Cherts from south Texas were chipped into bifaces and used to cut and scrape soft wood; in al1 cases the edge damage (under microscopic examination) was similar to that described by Tringham (ibid.). Flakes were also used for cutting and scraping soft wood; like results were obtained. Each of the experimental tools was used 100 times to cut or scrape. 
The remainder of this chapter will present the results of the project as follows. First, the materials collected during the supplementary field investigations and analyzed in the laboratory will be described. Second, the 15 sites from which these materials were collected will be described. Third, information gained from all cultural resources documented in the study area will be presented and discussed in an attempt to synthesize the most significant descriptive information. Most of the collected materials are the products and by-products of aboriginal activities in the Choke Canyon Reservoir area. Most of these items are of stone, bone, or she11. Table 7 presents our general classification scheme and numbers of items in each category.

\section{Lithic Materials (3463 specimens)}

The most common lithic resource material in the reservoir area is a grainy brown or gray chert, occurring as cobbles. The grains are easily seen without the aid of a microscope; the color generally varies from a light tan to a dark gray; inclusions frequently occur. Finer grained and different colored local cherts are present but less common. Sometimes these cherts have a reddish or pinkish color, a waxy or greasy luster, and often numerous tiny fracture lines and spalls; these materials have probably been modified by heat (Hester and Collins 1974:221). Described specimens are of these local cherts unless otherwise noted. Where heat treating occurred, it is noted.

In our analysis, lithic materials are first differentiated by the major type of modification they have undergone, $i e_{.}$, chipped, ground, and heat-fractured.

\section{Chipped Stone (1337 specimens)}

In general, we have taken a traditional approach and divided chipped stone artifacts into morpho-technological classes. A similar approach was taken by Lynn, Fox, and O'Malley (1977) in their description of artifacts previously recovered from the reservoir area.

Artifact outline shape is described in conventional terms, as is cross section. Transverse cross sections are used unless otherwise stated. Edge angles are arbitrarily defined: low edge angles are less than $40^{\circ}$.

Basic categories used for chipped stone artifacts are cores, trimmed artifacts, unifaces, bifaces (including projectile points), and debitage (including flakes, chips, and shatter). Some of these categories are subdivided further on the basis of attributes such as size, shape, platform, and cortex. The range of sizes for each subcategory is given in the descriptions.

Most artifact categories are illustrated by a photograph of at least one specimen. The artifacts were coated with ammonium chloride before photographing in order to allow effective photography of details of flake scars. 
CORES (120 specimens; Table 8 )

Cores are lithic materials which have had one or more flakes removed through the intentional human application of force. Lithic raw materials used as cores must fracture conchoidally to produce the desired end results. Such materials (e.g., chert) are abundant and easily obtained within the Choke Canyon Reservoir area.

The following classification and description of cores is based on the number of flake removals, the direction of the flake removals, the type of platforms used for the detachment of flakes, and the size of the core.

\section{Tested Cores (23 specimens)}

These artifacts were flaked only a few times and then discarded. After initial exploration by flaking, they were presumably deemed unsuitable for further reduction activities. Shape is ovoid. Flakes were removed from unprepared (cortex) platforms.

of the collected tested cores, $76.2 \%$ were recovered from the surface of one site, 41 LK 152. This particular site probably functioned as a quarry area, where the initial core reduction activities were performed with regularity.

Specimens 1-6: Six specimens (Fig. 8,a) exhibit a single flake removal. Most of the flake scars are quite large with prominent negative bulbs of force remaining on the core. Size ranges are: length $98.00-200.00 \mathrm{~mm}$, width 77.05$145.00 \mathrm{~mm}$, thickness $45.80-115.00 \mathrm{~mm}$, weight $396.4-3005.1 \mathrm{gm}$.

Specimens 7-23: Seventeen specimens (Fig. 8,b) exhibit two to four flake removals. Three specimens indicate heat treatment. Size ranges are: length $62.15-175.00 \mathrm{~mm}$, width 54.75-116.75 mm, thickness 31.10-102.70 mm, weight.216.3-1777.7 gm.

\section{Unidirectional Cores (26 specimens)}

Cortex Platform (14 specimens)

These cores (Fig. 8,e) are generally tabular in shape and oval in outline. Flakes were struck primarily in one direction, using a cortex-covered edge as a platform for the flake removals. The result of such a reduction process is a pyramid-shaped core, with the point of the pyramid being the flake termination area. This point may still exhibit the original cortex of the core. The base of the pyramid will be the flat face of the core which is still covered with cortex, whose edges were used as platforms for flake removals.

Most of these specimens have undergone a symmetrical reduction sequence. Flakes have been removed from the cortex-covered edge at almost all possible points along the core edge. Several specimens exhibit flake scars which run up the cortex face of the core. These few flake scars (generaliy one or two per core) are not considered to be the primary intended flake removal, since so few flake scars are involved. Two specimens exhibit large flake scars on one face which indicate previous and now obscured attempts to flake the core from another 
Figure 8. Lithic Artifacts: Cores, Trimmed Cobbles, Flakes, and Chips. a, tested core, Specimens 1-6; b, tested core, Specimens 7-23; c, secondary core; d, unidirectional core, prepared platform; e, unidirectional core, cortex platform; f, multidirectional core, prepared platform, Specimens 1-18; g, multidirectional core, prepared platform, Specimens 19-41; $h$, multidirectional core, prepared platform, Specimens 42-58; $i$, trimmed cobble, Specimens 8-10; j, trimmed cobble, Specimens 1-3; k, trimmed cobble, Specimens $4-7 ; 1$, unifacially trimmed flake, Specimens $1-3 ; \mathrm{m}$, unifacially trimmed flake, Specimens 4-5; $n$, unifacially trimmed flake, Specimens 6-13; 0 , unifacially trimmed flake, Specimen 14; p, bifacially trimmed flake; $q$, trimmed chip, Specimens $1-9 ; r$, trimmed chip, Specimens 10-13. 


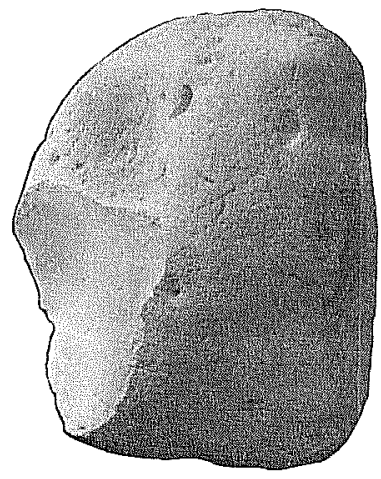

2

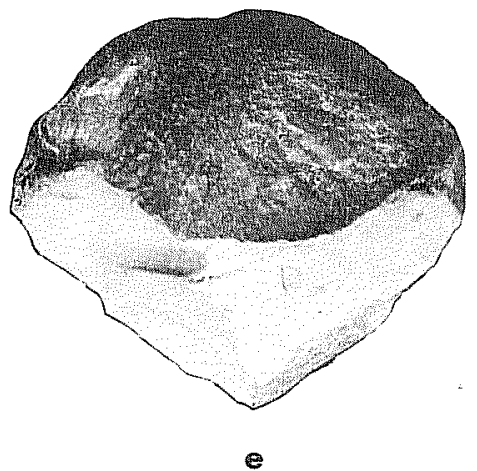

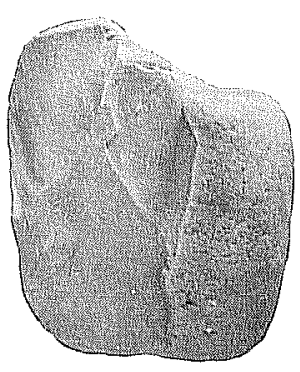

b

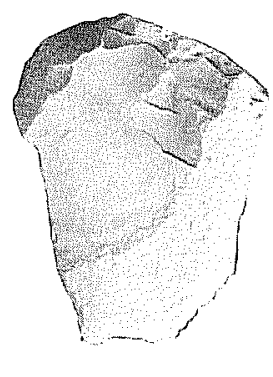

$c$

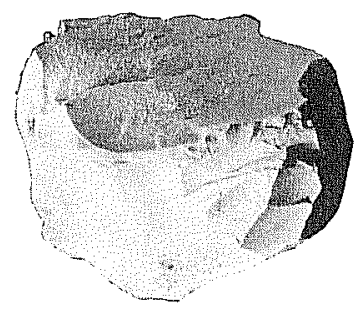

d

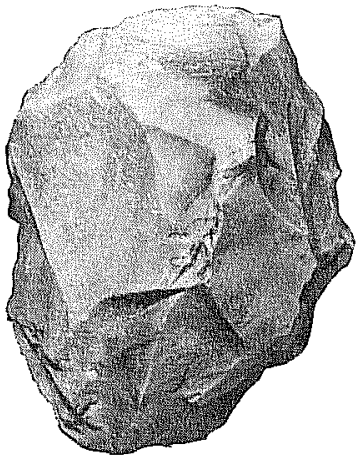

9
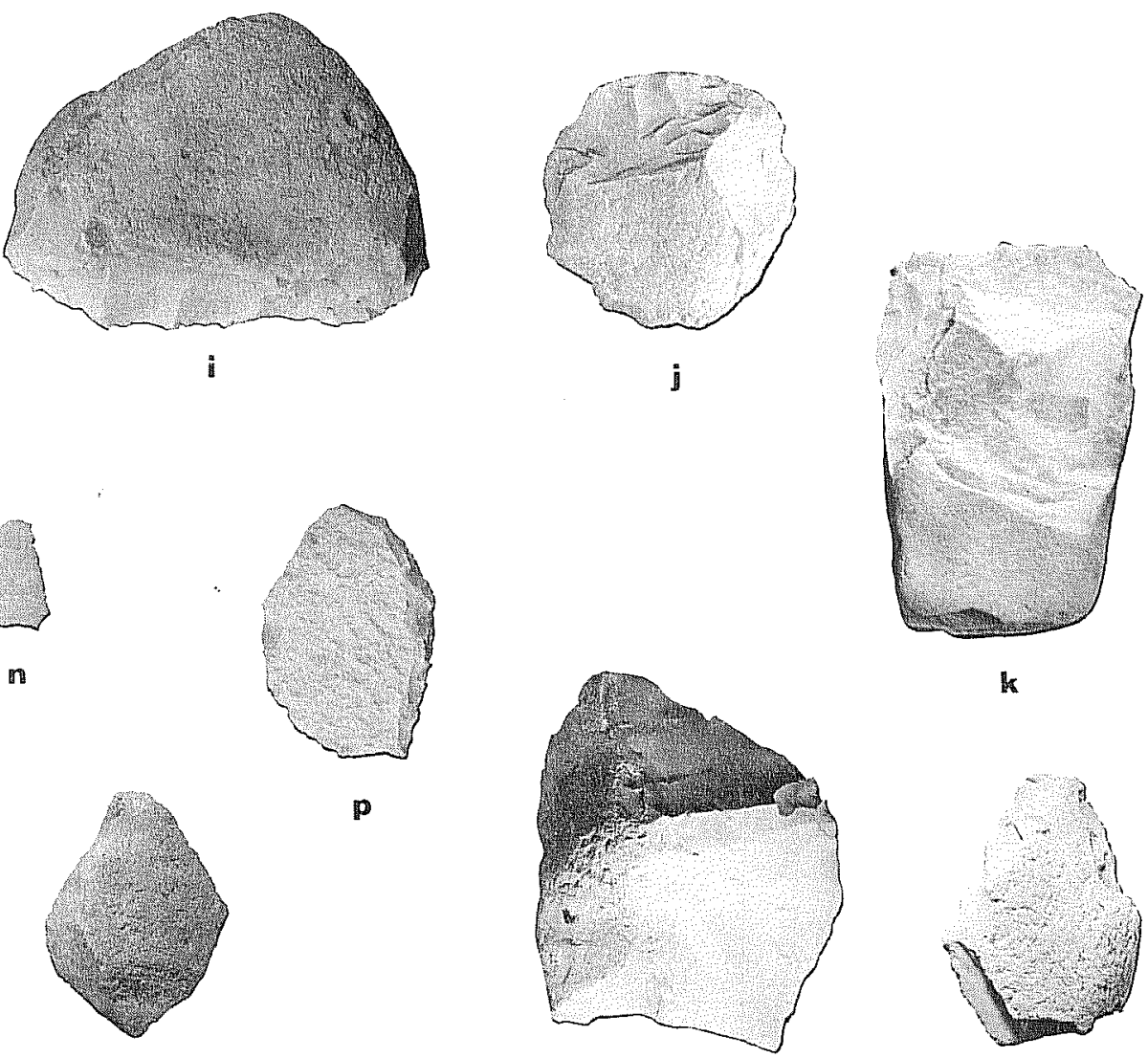

k

n
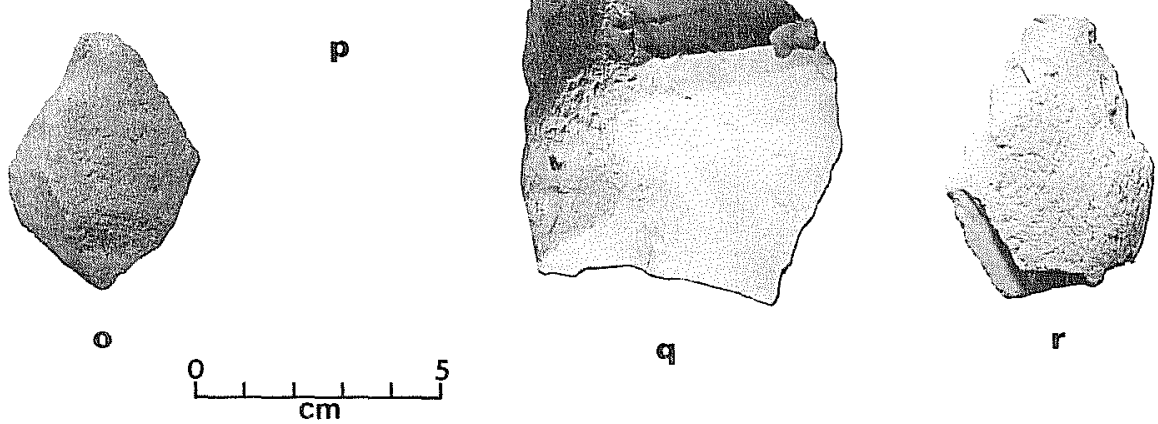
TABLE 8。 CORES

\begin{tabular}{|c|c|c|c|c|c|}
\hline Site Number & Tested & Unidi & ional & Multidirectional & Secondary \\
\hline & & $\begin{array}{l}\text { Cortex } \\
\text { Platform }\end{array}$ & $\begin{array}{l}\text { Prepared } \\
\text { Platform }\end{array}$ & Prepared Platform & \\
\hline 41LK31 & 1 & 1 & 1 & & \\
\hline 41LK32 & 2 & & 1 & 1 & 2 \\
\hline 41LK121 & 1 & 2 & 1 & 5 & 1 \\
\hline $41 L K 152$ & 18 & 4 & 3 & 10 & 4 \\
\hline 41LK159 & & & & 7 & \\
\hline $41 L K 171$ & & & & 6 & 1 \\
\hline 41LK181 & & 3 & & 7 & 2 \\
\hline $41 L K 183$ & & & 1 & 3 & \\
\hline 41MC199 & & 2 & & 1 & 1 \\
\hline $47 M C 201$ & & 2 & 4 & 9 & 2 \\
\hline 41MC209 & 1 & & & 5 & \\
\hline $41 M C 210$ & & & & 1 & \\
\hline $41 M C 214$ & & & & & \\
\hline $41 M C 217$ & & & 1 & 2 & \\
\hline $41 M C 225$ & & & & 1 & \\
\hline
\end{tabular}


direction. One specimen retains old cortex at the flake termination point on the (generally) noncortex face of the core. This cortex is unlike the cortex on the opposite face, and may indicate that a split cobble was utilized as a core. One specimen appears to have been heat treated and exhibits a battered end. It probably also functioned as a hammerstone. Heat treatment may have caused the yellowish red color of another specimen. Size ranges are: length 49.50-124.85 mm, width $34.75-101.95 \mathrm{~mm}$, thickness $16.85-68.05 \mathrm{~mm}$, weight 28.8 $1034.7 \mathrm{gm}$.

\section{Prepared Platform (12 specimens)}

These cores (Fig. 8,d) are generally nodular and exhibit irregular outlines. All of these cores retain a large flake scar which provided a prepared platform for the subsequent unidirectional removal of flakes. In most specimens, the flake removals and the platform flake scar are almost perpendicular to each other. Several of the larger specimens have more than one platform preparation flake scar. Most of the specimens included in this core category retain at least $50 \%$ of the original cortex. One specimen is petrified wood. Size ranges are: length $28.25-112.40 \mathrm{~mm}$, width $26.90-84.05 \mathrm{~mm}$, thickness $26.00-69.05 \mathrm{~mm}$, weight $30.0-706.4 \mathrm{gm}$.

\section{Multidirectional Prepared Platform Cores (58 specimens)}

These are characterized by the removal of flakes in at least two different directions. Flake removals were made from platforms which had been prepared by the prior removal of at least one large flake. A few specimens also use unprepared platforms in addition to prepared platforms, but these occurrences are relatively infrequent.

Specimens 1-18: Eighteen specimens (Fig. 8,b) have been reduced by means of flake removals in two different directions, using (for the most part) prepared platforms. Both tabular and ovate forms were recorded. The amount of cortex remaining on these cores ranges from about $50 \%$ to about $10 \%$. One specimen is flaked primarily in one direction, but flaking in another direction occurs frequentiy enough to consider it as a bidirectional prepared platform core. One specimen was of petrified wood. Size ranges are: 1ength $65.50-111.30 \mathrm{~mm}$, width 40.30-100.80 mm, thickness $21.95-87.10 \mathrm{~mm}$, weight 87.2-931.6 gm.

Specimens 19-41: Twenty-two specimens are characterized by flake removals in more than two distinct directions. The vast majority of these flake removals are made from platforms which have been prepared by the previous removal of one or more flakes. Cortex remaining on these items ranges from about $50 \%$ to about $20 \%$. There is extensive variability in size, shape, and color. Both ovoid and tabular shapes occur in this subcategory, with oval, rectangular, and irregular outlines. One specimen is of petrified wood. Two specimens have been heat treated. Size ranges are: length $52.60-119.5 \mathrm{~mm}$, width $35.50-91.70 \mathrm{~mm}$, thickness $22.85-87.20 \mathrm{~mm}$, weight $59.9-941.4 \mathrm{gm}$.

Specimens 42-58: Another 17 specimens (Fig. 8,h) also exhibit flake removals from more than two distinct directions. Previous flake removals (one or more) provide the platform for subsequent flake removals. The size is small relative 
to al1 cores from all other categories. Cortex covers 1ess than $40 \%$ of the surface on most of these cores. Both tabular and ovoid shapes occur with outlines ranging from irregular to oval. Two specimens were heat treated. The small size, lack of cortex, and multidirectional nature of these items indicate that they probably represent the end result of the lithic reduction sequence (then discarded)。 Size ranges are: length $34.65-82.00 \mathrm{~mm}$, width $27.60-45.50 \mathrm{~mm}$, thickness 15.90-35.25 mm, weight $17.6-89.2 \mathrm{gm}$.

\section{Secondary Cores (13 specimens)}

We followed Schaafsma's (1977:183) concept of secondary core which defined these artifacts (Fig. 8,C) as ". . . large flakes, from which smaller pieces of debitage have been removed. They display a large positive bulb of percussion (force) and one or more smaller, negative debitage scars." Thought of in another way, these items are large pieces of cores which have themselves been detached from larger cores. While these core fragments retain some negative flake scars from previous core reduction activities, one side of the artifact is marked by a positive bulb of force and flake striking platform which indicate where these secondary cores were removed.

Eight items appear to have been heat treated. Cortex remaining on the specimens was most extensive on the secondary cores which have not been heat treated. The amount of cortex on these items varies from $50 \%$ to about $10 \%$, with the majority of specimens retaining cortex on about $30 \%$. Secondary cores which do exhibit signs of heat treatment generally retain about $20 \%$ cortex on their remaining faces. This value ranges from $40 \%$ to $10 \%$. Size ranges are: length $37.70-72.10 \mathrm{~mm}$, width $22.30-56.60 \mathrm{~mm}$, thickness $13.75-36.95 \mathrm{~mm}$, weight $13.00-158.0 \mathrm{gm}$.

TRIMMED ARTIFACTS (44 specimens; Table 9)

Trimmed Cabbles (10 specimens)

These are tabular cobbles which have been marginally flaked (or trimmed) along one or more edges and upon one or both faces. All retain cortex on one or both faces.

Both primary and secondary flake removal scars can be seen on the worked portions of these artifacts. Enough of the original cobble exists to allow identification of the cobbles general shape and size.

Specimens 1-3: On three trimmed cobbles (Fig. 8,j), unifacial trimming has formed steep edge angles along one edge of these artifacts. One specimen is oval in shape and biconvex in cross section; one specimen is trianguloid in shape and rectangular in cross section; one specimen is irregular in outline and plano-convex in cross section. Microscopic examination revealed step fracture scars (terminating abruptiy in a right angle break) and a few scalar flake scars (from scalelike micro-flakes) on the extreme edge of the worked faces; the reverse faces also exhibited a few step fracture scars. These wear patterns also showed medium abrasions on small protrusions. These trimmed cobbles are morphologically similar to the Group III core tools described by 
TABLE 9. TRIMMED ARTIFACTS

\begin{tabular}{|c|c|c|c|c|}
\hline Site Number & Cobbles & Unifacially trimmed & $\begin{array}{l}\text { es } \\
\text { Bifacially trimmed }\end{array}$ & Chips \\
\hline 41LK31 & 1 & & & 1 \\
\hline 47LK32 & 1 & 4 & & 5 \\
\hline $47 L K 121$ & 1 & 1 & & \\
\hline $47 L K 152$ & 2 & 3 & 4 & 1 \\
\hline 41LK159 & 1 & 2 & 1 & 1 \\
\hline 41LK171 & 1 & 1 & & \\
\hline 41LK181 & 1 & & 1 & 1 \\
\hline \multicolumn{5}{|l|}{ 41LK183 } \\
\hline \multicolumn{5}{|l|}{ 41MC199 } \\
\hline 41MC201 & 2 & 2 & & 2 \\
\hline 41MC209 & 1 & . & 1 & 1 \\
\hline \multicolumn{5}{|l|}{$47 M C 210$} \\
\hline \multicolumn{5}{|l|}{$47 M C 214$} \\
\hline $41 M C 217$ & & 1 & & \\
\hline
\end{tabular}


Lynn, Fox, and 0'Malley (1977:49). Size ranges are: length $55.60-115.10 \mathrm{~mm}$, width $53.90-94.60 \mathrm{~mm}$, thickness $18.00-39.95 \mathrm{~mm}$, weight $61.0-383.8 \mathrm{gm}$.

Specimens 4-7: Four of the trimmed cobbles (Fig. 8,k) also exhibit unidirectional and unifacial primary and secondary flake removals from one edge of the artifact, forming generally steep edge angles at the worked edge. Prior to these flake removals, however, the cobble was split to form a prepared platform for flake removals.

One specimen is irregular in outline and plano-convex in cross section. Another specimen is oval in outline and biconvex in cross section on one end. The biconvex end is the remnant of the original cobble, since the longitudinal splitting of this specimen experienced a hinge fracture (right angle break just before flake termination) before reaching the end of the cobble.

Two additional specimens are roughly rectanguloid and irregular in outline. Cross sections are biconvex on one and flat on the other. One of these specimens is of heat-treated petrified wood.

The chert specimen retains evidence of attempts to longitudinally split a tabular cobble. The altered end has then been trimmed by primary and secondary flaking to remove generally short, wide flakes and create a relatively steep edge angle. Size ranges are: length $72.75-120.20 \mathrm{~mm}$, width $39.70-75.05 \mathrm{~mm}$, thickness $14.40-33.60 \mathrm{~mm}$, weight $43.5-217.4 \mathrm{gm}$.

Specimens 8-10: Three trimmed cobble (Fig. 8,i) specimens are tabular cobbles which have been flaked primarily in one direction on one face and then flaked a few times on the other face. For the most part, these artifacts have a steep edge angle where the edge has been flaked predominantly in one direction with primary and secondary flake removals.

Two artifacts are generally trianguloid in overall shape and plano-convex in cross section. One is roughly ovoid in outline and wedgelike in cross section. Size ranges are: length 74.15-127.20 mm, width $42.00-76.60 \mathrm{~mm}$, thickness 27.80-30.20 mm, weight 101.1-346.8 gm.

\section{Trimmed Flakes (21 specimens)}

These are flakes that have undergone only marginal flaking; neither face of the artifact is completely covered by flake scars. They exhibit flaking on the perimeter at various locations. Either unifacial or bifacial flaking may occur, although bifacial flaking patterns on trimmed flakes probably could obscure the original flake's bulb of force and platform (and this would make it a chip). Our collection of trimmed flakes contained only two bifacial specimens.

The categories described below are based upon morphological characteristics. Since all of these artifacts are made from flakes, they exhibit a positive bulb of force and a platform. Morphological categories of trimmed flakes are determined by the location of the worked edges relative to the original flake's proximal end (i.e., the end with the bulb of force and platform). This morphological distinction was preceded by the determination of whether the flake was bifacially or unifacially trimmed (trimmed on both faces or just one face). 


\section{Unifacially Trimmed (14 specimens)}

These trimmed flakes have undergone flaking on only one face of the flake. Almost all of them have been flaked on the dorsal surface of the flake.

Specimens 1-3: Three unifacially trimmed flakes (Fig. 8,1) have been trimmed on the original flake's distal end and on two lateral edges. One specimen is a hard-hammer flake that is irregularly oval in outline and plano-convex in cross section. The distal end of this artifact has been trimmed by primary and secondary flakes that have created a relatively steep edge angle.

A second specimen is made on a large, roughly triangular, hard-hammer flake. Most of the dorsal surface retains cortex. Areas of trimming have been subject to primary and secondary flake removal and microscopic edge damage. Some incidental ventral face flakes have been removed, and these were taken from one lateral edge only.

The other specimen has no cortex and may have been subjected to heat treatment. It is irregular in shape. No edge wear, except very light abrasion, was noted on the ventral surface edges of this artifact. The dorsal surface edges reveal predominantly step fracture scars with some scalar flake scars. The lateral edges also are denticulated, while the end edge is not denticulated. Size. ranges are: length $34.55-91.05 \mathrm{~mm}$, width $30.90-68.60 \mathrm{~mm}$, thickness $7.60-25.10 \mathrm{~mm}$, weight $6.1-131.2 \mathrm{gm}$.

Another example of this kind of uniface was recorded (but not collected) at site 41 LK 31.

Specimens 4-5: Two unifacially trimmed specimens (Fig. 8,m) exhibit unifacial flake removals from the distal end of the original flake and on one lateral edge. The specimens retain a large amount of cortex on the dorsal surface, are oval in outline, and plano-convex in cross section. The specimens are made from hard-hammer percussion flakes.

Microscopic examination of the artifacts revealed predominantly scalar flake scars and some step fractures on the dorsal face of the worked edges but no apparent edge damage on the ventral face of the worked edges. Some protrusions were rounded and abrasion was light over the working edges. Sizes are: length 54.20 and $81.65 \mathrm{~mm}$, width 38.10 and $44.65 \mathrm{~mm}$, thickness 10.25 and $25.50 \mathrm{~mm}$, weight 24.0 and $102.6 \mathrm{gm}$.

Field notes from the 1977. Choke Canyon Reservoir survey indicate that an example of this subcategory of trimmed flakes also occurred at site 41 LK 31.

Specimens 6-13: A group of 8 unifacially trimmed flakes (Fig. 8,n) exhibits only one working edge: a lateral edge of the original flake. Little or no cortex is evident on the dorsal face. Two specimens were probably heat treated.

Three specimens exhibit microscopic edge damage in the form of scalar flake scars on the dorsal face of the lateral edge. It should be noted that the distal ends of these unifacially trimmed flakes have all been broken (either snapped or hinged). Four specimens exhibit no apparent edge damage while the 
edge of one specimen is lightly abraded. Size ranges are: length 24.40$54.05 \mathrm{~mm}$, width $17.25-44.55 \mathrm{~mm}$, thickness $5.50-16.40 \mathrm{~mm}$, weight $2.3-47.3 \mathrm{gm}$.

Field notes indicate that another trimmed flake was observed at site 41 LK 31 , but it was not collected.

Specimen 14: This flake (Fig. 8,0) has been worked only on the distal end of the original flake. The end of this flake is relatively broad, so a long working edge could have been made. Cortex appears on the dorsal surface. The artifact is ovoid in shape; its cross section is plano-convex. It is $55.00 \mathrm{~mm}$ long, $38.65 \mathrm{~mm}$ wide, $14.05 \mathrm{~mm}$ thick, and weighs $29.1 \mathrm{gm}$.

\section{Bifacially Trimmed (7 specimens)}

These items are (Fig. 8,p) generally ovoid to trianguloid in plan view, planoconvex in cross section, and are generally made from hard-hammer percussion flakes. Both faces of the flake have been worked either on the distal end of the flake and on at least one lateral edge, or on both ends and one lateral edge, or on both lateral edges. Two specimens have probably been heat treated.

Microscopic examination of one specimen revealed a steep edge covered primarily with step fracture scars and a few scalar scars. All scars were on the dorsal surface.

One specimen is worked primarily on the dorsal surface at the distal end of the original flake. This specimen retains extensive step fracture scars, a few scalar scars, and abrasion on the dorsal face on this end. One lateral edge of this artifact has been worked (by secondary flaking) on the ventral face and edge damage is not apparent.

Bifacial trimming has occurred on the distal end of one specimen, while unifacial trimming is limited to one lateral edge. Abrasion and step fractures abound on the dorsal face of the unifacially worked lateral edge, al though a few scalar scars were also observed. Extreme abrasion was observed on the bifacially worked end and on the other lateral edge. Conditions such as stream action may be responsible for the abrasion and may possibly be responsible for the limited nature of the bifacial retouch.

One specimen has been bifacially trimmed on both lateral edges. This flake is quite large and has been detached from a large core and trimmed in a few limited areas. A few Tocalized areas of heavy abrasion were noted with microscopic examination, along with bifacial scalar flake scars. Step scars are not common.

The bifacially trimmed Tateral edge of one specimen has not been used, but this specimen's distal edge has been unifacially trimmed and the dorsal face edge is extremely rounded and covered with primarily step fracture scars and a few scalar flake scars. No edge wear damage was apparent on the ventral face of this unifacially trimmed edge.

The remaining bifacially trimmed flake exhibited two different types of use-wear and may have been a multipurpose tool. One lateral edge had scalar flake scars 
on both faces of the edge. Both ends have also been used after being unifacially trimmed to form relatively steep edge angles. The proximal end is also unifacially trimmed and has slight abrasion and scalar flake scars as well as some step fracture scars on the ventral face. Size ranges are: length 46.45-90.55 mm, width $36.10-67.35 \mathrm{~mm}$, thickness $10.15-34.75 \mathrm{~mm}$, weight 22.7 $146.6 \mathrm{gm}$.

\section{Trimmed Chips (13 specimens)}

Trimmed chips are identical to trimmed flakes except that the striking platform of the flake is not present on chips. Trimming on these artifacts takes the form of primary and secondary flake removals on some portion of the chip's perimeter, and the flaking does not cover one or both faces of the chip. Artifact trimming may be either on one face (unifacial) or on two faces (bifacial).

Specimens 1-9: Nine of the trimmed chip specimens (Fig. 8,q) have had primary and secondary flakes removed from one face of the chip, and can be referred to as unifacially trimmed chips. A11 are generally irregular in shape except for one specimen which is roughly rectangular, and another specimen which is semicircular in outline. A11 of the specimens (except for one) are roughty plano-convex in cross section. The exception is biconvex in cross section. Except in three specimens, cortex almost completely covers the dorsal surface of the unifacially trimmed chips. Heavy patina covers one specimen. Grainy inclusions were observed in the chert of one artifact. Heat treatment is evident in two specimens and possibly another.

Primary and secondary flake scars are most pronounced on two specimens, and these artifacts also exhibited the steepest edge angles. In comparison, the remaining seven artifacts have fewer primary and secondary flake scars, and these are located in much smaller areas of the edge of the chips. Their edge angles are low except in one specimen which has a high edge angle. These latter artifacts are also much smaller in overall size. Microscopic examination of the two smallest specimens shows that the retouched edges also provide evidence of scalar flake scars and step fracture scars. These scars also extend along edges which have not undergone previous flaking in either primary or secondary flake form. The scalar flake scars and the step fracture scars extended on both faces of the edges involved, especially away from the loci of primary and secondary flaking. Light edge abrasion also exists near the microscopic edge scars.

One artifact exhibits a heavily abraded edge, primarily with scalar scars, and another exhibits only light edge abrasion. Heavy abrasion and rounding, numerous step fracture scars and a few scalar scars occur continuously along the trimmed edge, and these scars are located on the dorsal face of the worked edge.

One specimen is probably a multipurpose tool. The trimmed edge's dorsal face is lightly abraded and contains a few scalar flake scars. The other edge, which is untrimmed, exhibits deep scalar flake scars on both faces of the edge. 
The other three unifacially trimmed chips were also examined microscopically. One specimen exhibited a few scalar flake scars and mostly step fracture scars along the trimmed edge. These scars, which were readily apparent, were concentrated in several loci along the edge and were confined to the dorsal face of the edge. The other artifact does not have a very flat ventral surface (when compared to the previously described artifact) and exhibits different micro-wear along the retouched edge. Heavy abrasion, coupled with predominantly step fracture scars, is concentrated at various edge locations and upon both faces. A genera11y denticulated edge was also observed.

An additional unifacially trimmed chip is a large, generally oval piece whose unworked face is completely covered with cortex. This item exhibits a planoconvex cross section. The striking platform and bulb of force have been obliterated. Only localized and infrequent primary and secondary flakes have been removed from the thin edges of this specimen. These flakes have been taken from the cortex-free face of the chip and generally terminate in hinge fractures. A11 edges of the chip were examined with a microscope to view any possible edge use-wear. However, no identifiable edge wear was noted. Size ranges are: length $21.60-94.80 \mathrm{~mm}$, width 19.60-64.85 mm, thickness 3.60$33.15 \mathrm{~mm}$, weight 1.4-153.9 gm.

Other sites in Choke Canyon Reservoir that were recorded in 1977 and contained examples of unifacially trimmed chips were 41 LK 139 and 41 LK 174.

Specimens 10-13: These trimmed chips (Fig. 8,r) are distinguished by the bifacial removal of primary and secondary flakes (retouch) along their edges. One specimen is large and retains some cortex on both faces. This item is irregular in outline and roughly plano-convex in cross section. Both primary and secondary flakes have been removed from both faces of one edge of this chip. Microscopic edge wear analysis revealed little or no sign of damage of any form which could be indicative of the tool's use. This was one of the cases where no positive and regular evidence of use-wear could be identified on the edge of an artifact.

Three other specimens are (respectively) circular, roughly oval, and irregular in shape; all are plano-convex in cross section. Edge trimming on one specimen consists of primary and secondary flakes. Two edges have undergone hinge fracture and have not been trimmed, and one face has been more extensively trimmed than the other. Edge angles are not particularly steep. Microscopic examination of the trimmed edges reveals predominantly scalar flake scars with occasional step fracture scars. These scars are located primarily on the dorsal face (not the flat face) of the edge, and there is abrasion of this same face edge.

One artifact exhibits two steep edges which have been trimmed by deep, wide, and large primary and secondary flake removals from both faces, with the steep face having most of the flake removals. One edge has been hinge fractured. Microscopic use-wear was observed on al1 edges. The two edges which have been bifacially trimmed revealed heavy pitting and abrasion, especially at protrusion points. Step fracture scars also appear on both faces of these edges, but most of these scars appear on the face opposite the flatter (ventral) face. The fractured end of this artifact also exhibits micro-use wear. Both faces of the edge are rounded and abraded, and a few step fractures were recorded on one face. 
The remaining bifacially trimmed chip has alternately beveled edges and one trimmed end. While no bulb of force or platform was recognized on the ventral (flat) surface of this artifact, a point of extreme battering was noted on the untrimmed end. This may be the remnant of a bipolar flaking technique for flake removal from a core (Sollberger and Patterson 1976). The trimmed edges and one end have been formed by removal of short, wide primary and secondary flakes. One edge may have been further trimmed by pressure flaking. Both the trimmed edges and end revealed extensive abrasion and step fracture scars on one face of the edge (or end). Size ranges are: length $51.70-93.20 \mathrm{~mm}$, width 45.05-67.25 mm, thickness $11.95-32.65 \mathrm{~mm}$, weight 33.0-169.1 gm.

\section{UNIFACTAL ARTIFACTS (7 specimens; Table 10)}

This section wi11 provide a brief description of unifacial artifacts, i.e., those artifacts which have been completely (or almost completely) flaked on one face. If a flake or chip was imcompletely flaked on one face, then it was termed a unifacially trimmed artifact. Almost all of the items categorized as unifacial tools have been manufactured from flakes, and the relatively flat unmodified flake ventral surface also exists as the ventral surface for these artifacts.

Unifacial tool description and categorization follow Frkuska and Frkuska's (1977) discussion and classification scheme from the Hop Hill site in central Texas. These investigations utilized Crabtree's (1972:97) definition of a unifacial artifact, which is similar to the general definition indicated in the beginning of this section. Their definition also includes what we termed "unifacially trimmed flakes and chips"; this probably allows them a larger sample size for analysis. Our orientation is similar to Frkuska and Frkuska's, as we will report a series of metric and nonmetric measurements and observations to isolate "the definitive quality of a specific uniface or subgroup that makes it different from another specific uniface or subgroup" (Frkuska and Frkuska 1977:189). Morphological and technological description wil1 allow comparisons with similar artifact forms from previous archaeological studies from adjoining geographic areas (Weir 1976; Gunn and Mahula 1977) as wel1 as from previous archaeological studies in the Choke Canyon Reservoir area (primarily Lynn, Fox, and O'Ma11ey 1977).

\section{Complete Unifaces (3 specimens)}

Specimens 1-2: These specimens (Fig. 9,a) exhibit unifacial flake removals along all artifact edges. Both artifacts are trianguloid in shape and planoconvex in cross section. The dorsal surface of one specimen still retains a small amount of cortex, while the dorsal surface of the other specimen is completely free of cortex.

Both specimens are made from flakes and both retain steep edge angles on al1 edges. The steep edge angles are formed by both primary and secondary trimming along the extent of the artifact's perimeter.

Each unifacial artifact was examined microscopically at low power magnification of $10 \mathrm{X}$ and 20X. A11 edges of the perimeter were examined on both the dorsal and ventral sides. The lateral edges of one specimen exhibit scalar flake 
Figure 9. Lithic Artifacts: Unifaces and Bifaces. a, complete uniface, Specimens 1-2; b, complete uniface, Specimen 3; c, incomplete uniface, Specimens 1-2; d, incomplete uniface, Specimens 3-4; e, thick biface, ovate/ovoid, Specimens 1-3; f, thick biface, ovate/ovoid, Specimens 4-12; $\mathrm{g}$, thick biface, ovate/ovoid, Specimen 13-19; $h$, thick biface, round; $i$, thick biface, rounded end, Specimens 1-4; $j$, thick biface, rounded end, Specimens 5-7; k, thick biface, rounded end, Specimens 8-9; 1 , thick biface, rounded end, Specimens 10-11; m, thick biface, rounded end, Specimens 12-14; $n$, thick biface, beveled end; 0 , thick biface, small, end fragment; $p$, thick biface, small, medial fragment; $q$, thin biface, wide, base fragment; $r$, thin biface, wide, medial fragment; $s$, thin biface, wide, tip fragment. 


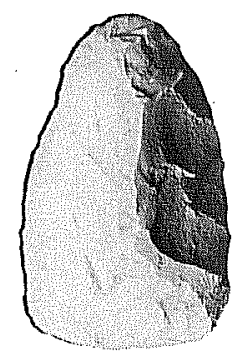

a

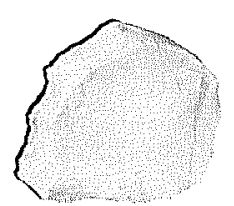

b

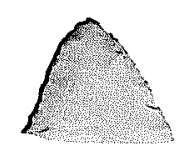

c

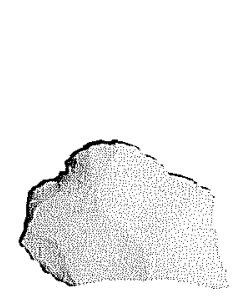

d

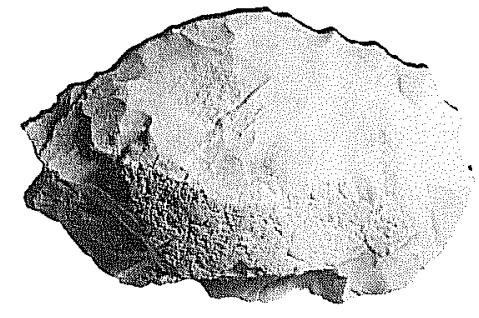

e

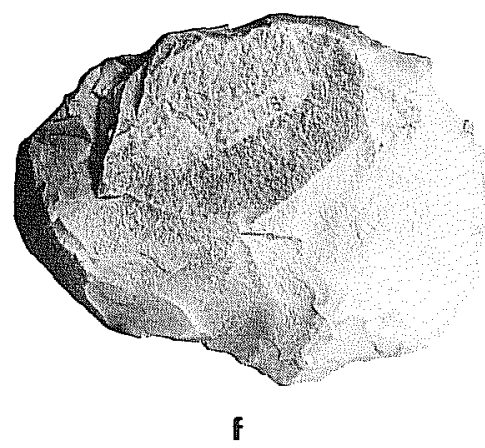

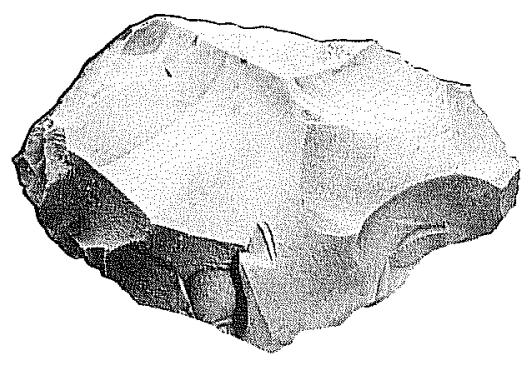

9

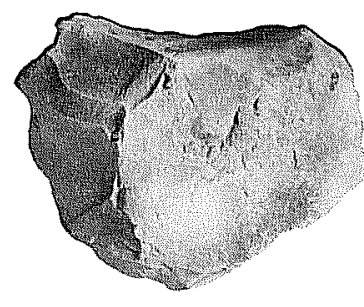

h

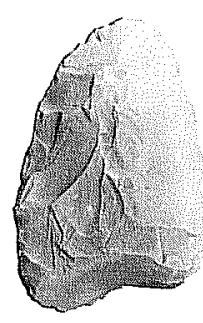

i
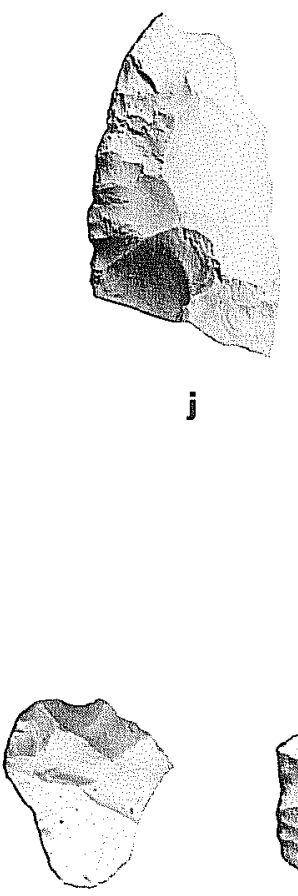

0

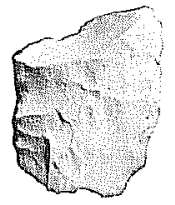

p

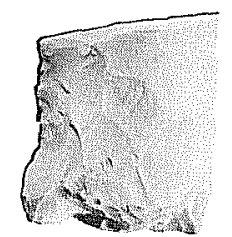

k

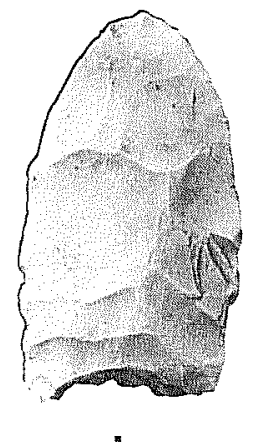

I

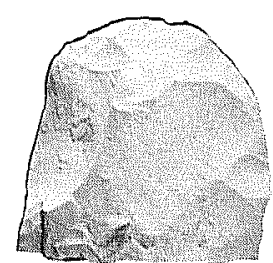

ตา

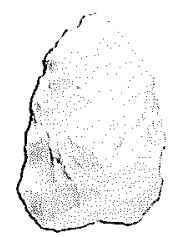

n

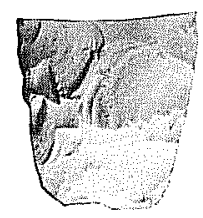

q

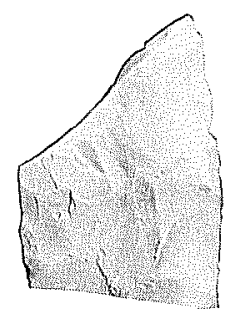

$r$

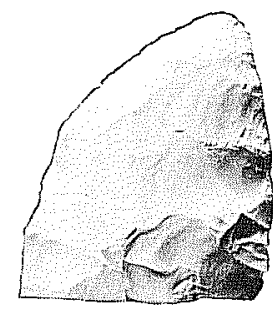

s 
TABLE 10. UNIFACIAL ARTIFACTS

Site Number

$41 L K 31$

$41 L K 32$

$41 L K 121$

$41 L K 152$

$41 L K 159$

$41 L K 171$

$41 \mathrm{LK181}$

$41 L K 183$

$41 M C 199$

$41 M C 201$

41MC209

$41 M C 210$

$47 M C 214$

$41 \mathrm{MC} 217$

$41 M C 225$

Isolated Find \#5
Complete

Incomplete

0 . 0

0

0

0

1

1

0

0

0

0

0

0

0

1

0

0

0

0

0

0

0

0
0

0

0

1

0

1

0
0
0
1
0
0
1
0
0
1
0
0
0
0
1


scars along with occasional step scars. These scars are located primarily on the dorsal face of the artifact. One lateral edge has a portion which exhibits predominantly step scars on both the dorsal and ventral surface. The ends of this specimen possess micro-wear edge damage in the form of primarily scalar flake scars with some step fractures. Edge damage occurs on both faces of the ends. Examination of the other artifact revealed similar patterns of microwear edge damage. Both artifacts have had secondary flaking on one face to shape the perimeters into a relatively straight edge. Sizes are: 1ength 71.10 and $72.65 \mathrm{~mm}$, width 43.05 and $45.45 \mathrm{~mm}$, thickness 12.30 and $18.40 \mathrm{~mm}$, weight 42.0 and $59.4 \mathrm{gm}$.

Specimen 3: This specimen (Fig 9,b) is a finished and complete uniface made from a flake. Cortex exists near the platform end of the uniface and along one lateral edge. The ventral side of this artifact still bears a negative bulb of force. This artifact has a generally ovoid shape and plano-convex cross section and retains high edge angles on its worked edges.

Microscopic examination reveals numerous step fractures and some scalar fractures, a11 of which are located on the dorsal face of the artifact. The general lack of micro-flake scars on the ventral surface combined with the type of edge micro-damage on the dorsal face probably indicate that this artifact was used for transverse action (scraping) of hard material (such as bone or antler), with the ventral face of the artifact being held closest to the material being scraped. The size is: length $55.75 \mathrm{~mm}$, width $54.10 \mathrm{~mm}$, thickness $20.80 \mathrm{~mm}$, weight $61.2 \mathrm{gm}$.

\section{Incomplete Unifaces (4 specimens)}

Specimens 1-2: These uniface fragments (Fig. 9, C) are triangular in shape, plano-convex in cross section, and have suffered a hinge fracture at one point along the perimeter of the artifact. Both items have relatively straight edges and evidence of secondary flake removals to shape the artifact. Both of these items retain no cortex, appear to have been heat treated, and were manufactured from flakes.

Microscopic edge damage in both cases is confined primarily to the dorsal face of the artifacts. Some sheen was observed on the ventral surfaces. The edge of the dorsal face of one artifact shows primarily scalar flake scars with an occasional step fracture as well as abrasion. Edge angles are not very steep. This artifact's perimeter also was well abraded. The fractured edge is untouched. The other specimen exhibited dorsal edge wear in the form of predominantly step fractures, some scalar fractures, and obvious abrasion. Steep edge angles are present on this artifact. The fractured edge has not been modified. Sizes are: length 26.55 and $48.40 \mathrm{~mm}$, width 32.65 and $42.05 \mathrm{~mm}$, thickness 8.10 and $10.15 \mathrm{~mm}$, weight 5.4 and $21.7 \mathrm{gm}$.

Specimens 3-4: These items (Fig. 9,d) are irregular in overall shape, planoconvex in cross section, and retain an edge that has been shaped. One specimen has probably been heat treated. Both specimens have been made from flakes, and both retain evidence of secondary flaking and straight edges. 
One specimen exhibits dorsal face edge wear in the form of both scalar and step fracture scars, in generally the same frequency. Ventral face edge wear is much less than the dorsal face, but numerous scalar and step fracture scars also occur on the ventral face edge. The other specimen exhibits predominantly dorsal edge wear, with scalar flake scars being more numerous than step fracture scars. Both specimens within this category present localized areas of light to medium abrasion. Sizes are: Tength 36.60 and $47.90 \mathrm{~mm}$, width 30.05 and $30.20 \mathrm{~mm}$, thickness 6.05 and $10.00 \mathrm{~mm}$, weight 6.2 and $12.8 \mathrm{gm}$.

\section{BIFACIAL ARTIFACTS (109 specimens)}

Bifaces are chipped stone tools with flake scars on both faces (Crabtree 1972:38). They are manufactured by reducing a cobble or a flake. During the manufacturing process flakes are removed from both faces using the same edge as a platform. As such, the edge of the biface generally describes a plane (Gunn and Ivey 1977:163). Bifaces generally have flake scars over at least one-half of both faces. However, in cases where cobbles (nodular or tabular) exhibit bifacial flaking along one or more edges, and the flake scars cover a considerable portion of the faces, we classify the artifacts as bifaces.

Bifaces are placed into categories based primarily on visual inspection of their general shape or morphology and technology or the appearane of the flake scars and the method of manufacture. Morphological nomenclature is used for each category. In many cases, categories are divided into subcategories based on finer morphological and technological divisions, e.g., bifaces less than $1.25 \mathrm{~cm}$ thick are termed thin. Function or type of edge damage on the tool is also used to subdivide categories.

Bifaces have been grouped into categories exhibiting similar characteristics or attributes for several reasons. This approach facilitates description and allows for comparison with bifaces from different areas, as well as with those recovered during other Choke Canyon studies. Biface categories in this study are generally comparable to those previously recovered from the Choke Canyon area and reported by Lynn, Fox, and O'Malley (1977), to those from the Hop Hill site in central Texas (Gunn and Ivey 1977), and to those included in the description of central Texas Archaic tool kits by Weir (1976). In some cases comparisons are made with accepted artifact types such as those put forth by Hester, Gilbow, and A1bee (1973).

Thick Bifaces (49 specimens; Table 11)

Ovatelovoid (19 specimens)

These bifaces are made from large tabular to slightly rounded cobbles or large flakes. We call them ovate (subrectangular) or ovoid (subtriangular) in shape. These bifaces characteristically exhibit cortex on one or both faces, but cortex generally covers less than $40 \%$ of the surface. The worked edges are convex and extend along we11 over $50 \%$ of the potential edge. Large percussion flakes, primarily with feathered terminations (tapered to a fine edge) but also some hinge terminations, were bifacially removed from the edge. Similar bifaces were observed at 34 of the 113 sites. All are biconvex in cross section with 
TABLE 11. THICK BIFACES

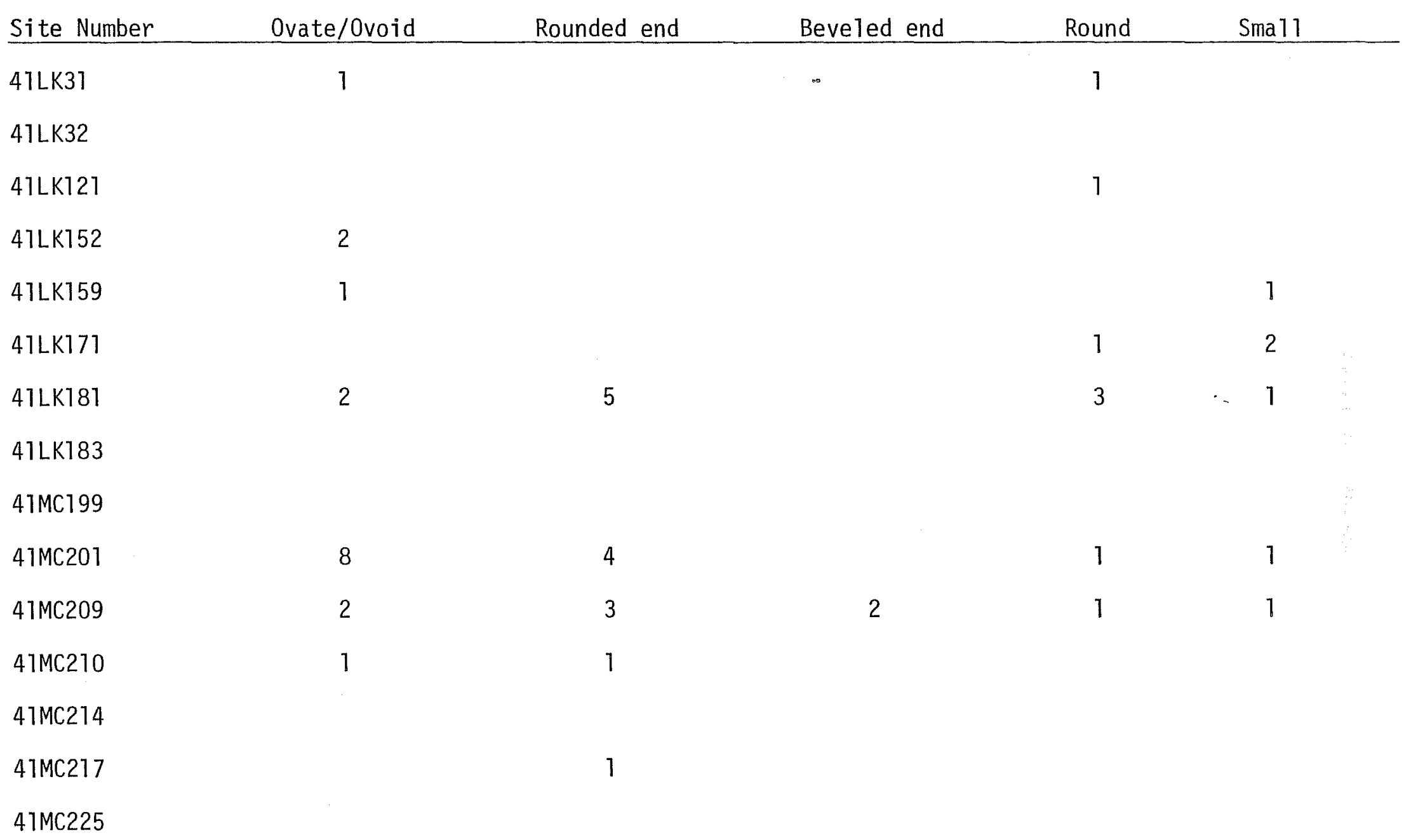


relatively high edge angles and sinuous edges. One specimen is of petrified palmwood. Six specimens were heat treated. Thick ovate/ovoid bifaces resemble "Oval and Ovate Bifaces" described by Gunn and Ivey (1977:177-179), "Group I Thick Bifaces" described by Lynn, Fox, and 0'Ma1ley (1977:61-63), and Weir's "Ovate Biface Cores" (1976:74-75). Bifaces in this category functioned primarily as cores, but some were used as tools, mainly for cutting and/or scraping materials such as wood or perhaps bone. These items may also have been subject to further reduction producing thinner bifacial tools.

Specimens 1-3: In these specimens (Fig. 9,e), flakes have been removed from the entire circumference, leaving cortex only on the interior of one face. They appear to be made from cobbles in that there are no obvious previous flake scars suggesting reduction of a large flake. Edges of these bifaces do not exhibit use-wear. Edge damage is primarily in the form of unifacial step fractures. This suggests that edge damage resulted from the intentional removal of flakes from the biface edge. These bifaces were probably used as cores with flakes being the desired product, or they may have been intended for further reduction to produce a thin biface tool. Size ranges are: length 92.45-105.00 mm, width 52.15-59.50 mm, thickness $30.55-33.20 \mathrm{~mm}$, weight 136.8$163.3 \mathrm{gm}$.

Specimens 4-12: These specimens (Fig. 9,f) exhibit cortex on both faces and small portions of the potential biface edge. They are made on cobbles. Edges are sinuous except where cortex remains. Small portions of the edge are unifacially flaked; other small portions exhibit cortex. These bifaces exhibit edge damage which is the result of the intentional detachment of flakes. Four have only this type of edge damage. Three specimens exhibit localized bifacial use-wear evidenced by scalar and step scars, but with a predominance of scalar scars on both faces. Two other specimens and one of those with longitudinal use-wear evidence transverse action in the form of both step and scalar scars along significant portions of the biface edge. Size ranges are: length $84.75-$ $113.10 \mathrm{~mm}$, width $52.15-81.45 \mathrm{~mm}$, thickness $26.20-54.05 \mathrm{~mm}$, weight 100.2-406.7 gm.

Specimens 13-19: These bifaces (Fig. 9,g) exhibit cortex on the edge and/or one face. They appear to have been made on large flakes as suggested by the presence of a platform or large flake scars on one face that could not have originated on the biface edge. Edges are characteristically sinuous being bifacially flaked, excepting small areas where cortex remains on one face at the edge. These bifaces exhibit edge damage from the intentional removal of large flakes. Five of these bifaces exhibit no readily detectable use-wear. One evidences slight transverse action use-wear consisting primarily of scalar scars with far fewer step scars, all of which are well worn. This wear pattern occurs at several places, but on one face only. The remaining specimen exhibits extremely abraded bifacial scalar scars and some step scars. Size ranges are: length 83.20-116.95 mm, width 40.00-74.20 mm, thickness 23.90-36.25 mm, weight 99. 1-236.8 gm.

\section{Rounded End (14 specimens)}

Bifaces in this category appear to be made from thick ovate/ovoid bifaces (as evidenced by the biconvex cross section) and from large flakes (as evidenced by portions of large flake scars that could not have originated from an earlier 
biface edge). Cross sections tend to be extremely biconvex, but some are almost plano-convex. Manufacture is by percussion, probably using a soft hammer. There is no evidence of fine trimming or pressure flaking. Edges are slightly sinuous to almost straight. Flake scars characteristically exhibit feathered terminations, but there are also numerous hinge terminations, especially on the coarser grained artifacts. Edge angles tend to be low. In three cases a small patch of cortex remains; two are on an edge and one is on a face. Edge angles are relatively high on specimens with cortex.

One artifact is of a dark brown glossy chertlike material which may have been heat treated. Three other artifacts also appear heat treated.

Only one specimen in the sample is considered to be complete, and a second specimen may have been reworked into a complete but stubby version. The complete specimen is similar to the bifacial clear Fork gouges (Hester, Gilbow, and Albee 1973; Lynn, Fox, and 0'Malley 1977:63, 67; Weir 1976:65), except that rounded end thick bifaces tend to be biconvex as opposed to plano-convex in cross section. "Group II, Form 3 Thick Bifaces" (Lynn, Fox, and O'Malley 1977: $63,65,69)$ are virtually identical to artifacts in this class. While most of rounded end, thick bifaces are fragments with rounded ends, their general shape and manufacturing techniques are very similar. In longitudinal cross section these specimens are thinnest: at the rounded end and thicken toward the opposite end. Similar specimens were observed at sites 41 MC 196, 41 LK 139, 41 LK 154, 41 LK 176, and 41 LK 182.

Specimens 1-4: These bifaces (Fig. 9,i) are trianguloid and exhibit a distinctive base. The base exhibits a higher edge angle than the lateral edges and is characterized by the removal of one large flake using the medial portion of one face as the platform. The result is a slightly indented base, and in three of the four cases smaller flakes have been removed from the edges of the base. It is suggested that these specimens were broken (probably during use), leaving a snapped end which was reworked primarily in an edge angle considerably less than a right angle (i.e., the angle of the snap). Use-wear is evident and similar on all specimens. Characteristically, wear takes the form of mostly scalar scars and fewer step fractures. Both types of scars are well worn (i.e., abraded), giving the appearance of a rounded edge. Use-wear tends to be bifacial on one lateral edge, unifacial on the other, and unifacial on portions of the base edge. Size ranges are: 1ength $49.00-64.95 \mathrm{~mm}$, width 37.70-51.25 mm, thickness 14.55-21.85 mm, weight 31.0-50.2 gm.

Specimens 5-7: These bifaces (Fig. 9,j) have medial snap fractures and their shape is trianguloid. The base ends have not been flaked. Use-wear is identical to that indicated for Specimens 1-4, except that none occurs on the bases. Size range is: width $40.65-48.50 \mathrm{~mm}$.

Specimens 8-9: These bifaces (Fig. 9,k) consist of base ends with portions of the lateral edges. Both have a medial hinge fracture. Use-wear on these artifacts is similar to that in Specimens $1-7$, but tends to be bifacial on both lateral edges and unifacial on the base of one specimen. The base of the other specimen and one lateral edge are extremely battered, resulting in many step fractures. The step fractures are confined to one face. We suggest that perhaps the latter tool did some light chopping, possibly of a medium material or even hard material such as bone. Sizes are: width 40.20 and $51.20 \mathrm{~mm}$. 
Specimens 10-11: These are two complete specimens, (Fig. 9,1) one of which is very short and may have been reworked. The bases of both artifacts are worked from one face to form a high edge angle. The lateral edges and the rounded end have a much lower edge angle. Edges exhibit use-wear similar to artifacts in the other specimen groups, but they tend to be bifacial on the lateral edges and rounded end. The base end has unifacial use-wear with a much higher incidence of step fractures. Sizes are: length 47.10 and $79.00 \mathrm{~mm}$, width 34.80 and $41.10 \mathrm{~mm}$, thickness 14.25 and $17.15 \mathrm{~mm}$, weight 25.7 and $65.7 \mathrm{gm}$.

Specimens 12-14: These bifaces (Fig. 9,m) are significantly larger than the other rounded end, thick bifaces. One is made from petrified palmwood. One (of chert) appears to be heat treated. No cortex remains on these bifaces. Two are biconvex in cross section. Two exhibit medial hinge fractures with the causal blow being struck from the missing end. One exhibits a snap fracture (the petrified palmwood). In longitudinal cross section, thickness increases from the end to the medial fracture. Edges are more sinuous than those of the smaller rounded end, thick bifaces. Edge angles are low. Flaking is by percussion and flake scars have mostly feathered terminations (some are hinge terminations). Secondary flaking has occurred on a 11 specimens. This category is 1ike "Group I, Form 6 Thick Bifaces" described by Lynn, Fox, and O'Malley $(1977: 59,62,64)$.

All three specimens exhibit edges evidencing use. Use-wear takes the form of relatively large scalar and step scars, with the former being predominant. While abrasion of these scars is apparent, it is significantly less than in the smaller rounded end, thick bifaces. Use-wear is bifacial and more evident on the rounded end than on the lateral edges. Size ranges are: width 50.75$61.75 \mathrm{~mm}$, thickness $13.20-20.10 \mathrm{~mm}$.

\section{Beveled End (2 specimens)}

These bifacially worked bifaces (Fig. 9,n) are thicker than $12 \mathrm{~mm}$ and are trianguloid to subtrianguloid in outline. One end is roughly pointed, while the opposite end exhibits a convex to straight steep bit formed by extensive unifacial primary and secondary flaking. Lateral edges are straight to slightly concave. Cross section of these thick bifaces are always plano-convex, which indicates a strong possibility that these items were manufactured from flakes. The most extensive flaking has occurred on the dorsal surface of the original flake and has removed al1 traces of cortex. Al1 perimeter edges, except the bit edge, of these two artifacts have been bifacially flaked. The bit edge of these artifacts has been steeply flaked primarily on one face. One specimen may have been heat treated.

These bifaces are most similar to the "Group II, Form 1" thick bifaces described by Lynn, Fox, and O'Malley $(1977: 59,63,67)$ from the previous survey of the Choke Canyon Reservoir. Morphologically similar specimens from adjoining areas have been recorded as "Group II, Form 1" thick bifaces from Cuero I Reservoir (Fox et al. 1974:40) and from Nuevo Leon, Mexico (Epstein 1969:34-43). They also resemble our rounded end, thick bifaces.

Microscopic examination for edge wear and damage on one specimen indicated extensive abrasion and numerous step fracture scars on the dorsal face of the 
lateral edges. The pointed end has been blunted and extreme abrasion and step fracture scars occur on the ventral face. The bit end showed much less abrasion and numerous scalar flake scars; a few step fracture scars are located primarily on the dorsal face of this edge.

Similar examination of the other artifact presented a different picture. The bit end was lightly rounded, and the lateral edges exhibited highly localized abrasion and step scar fractures at the loci of deliberate larger flake removals. slight abrasion was noted on the pointed end of the artifact. As a whole, usewear was not apparent and the edges were denticulated. Sizes are: 1ength 46.30 and $43.40 \mathrm{~mm}$, width 39.75 and $30.05 \mathrm{~mm}$, thickness 14.00 and $12.15 \mathrm{~mm}$, weight 18.9 and $18.6 \mathrm{gm}$.

Inspection of field notes from our survey indicates that similar gougelike thick bifaces were observed at 41 LK 127 (2 specimens), 41 LK 132, 41 LK 175, 41 LK 191, 41 LK 192, 41 MC 196, and 41 MC 205. The collected specimens described above were both from one site, 41 MC 209. In general, the gougelike thick bifaces recorded in the field were relatively thinner but larger in overall size with some dorsal cortex.

\section{Round (8 specimens)}

These bifaces (Fig. 9,h) are made on smal1, round to slightly tabular cobbles. They are generally biconvex in cross section, but one end forms a point and the other end is rounded. Approximately half of both faces and half of the potential biface edge have cortex. The worked edges are characteristicality curved and extend along approximately half of the potential biface edge. Large flakes (probably hard-hammer percussion), primarily with feathered terminations (but also some hinge terminations) were bifacially removed from the edge. Generally fewer than five flakes were struck from each face. Edge angles are high. A71 eight specimens are complete. One appears to be heat treated. This class of artifacts is similar to "Group I Core Tools" described by Lynn, Fox, and O'Malley (1977:49), to "End Bifaces, Oblique and Curved Choppers" described by Gunn and Ivey (1977:173), and to Weir's (1976:65, 74) "Latera1-cortex Bifaces and Ovate-biface Cores."

Five of the thick round bifaces do not exhibit significant use-wear but have edges that are battered at the loci of various flake detachments. Smal1 step fractures occur primarily on the edge near negative bulbs. This type of edge condition is probably the result of intentional flake detachment. Three specimens exhibit minimal bifacial use-wear along smal1 portions of the edge. Worn specimens tend to be smaller than unworn specimens. Use-wear takes the form of scalar and step scars on both faces. Abrasion is also evident on the tiny flake scars, especially along the edges. Size ranges are: length 56.80$74.25 \mathrm{~mm}$, width $49.05-75.50 \mathrm{~mm}$, thickness $26.00-51.20 \mathrm{~mm}$, weight 101.1$333.1 \mathrm{gm}$.

Small ( 6 specimens)

These bifaces (Fig. 9,0,p) are smaller versions of thick ovate/ovoid bifaces; however, only one example retains cortex (present on one face only). A11 
examples are extremely biconvex in cross section. None of the items is complete, but judging from the various fragments, shapes were ovate and ovoid with some specimens being rather elongated. Four are end fragments (Fig. 9,0), and two are medial fragments (Fig. 9,p). Fractures are both hinged and snapped. Lateral edges are characteristically convex, but some are straight and end edges are both rounded and pointed. Specimens exhibit only limited secondary percussion flaking, and edges are sinuous. Edge angles are high. One specimen is of dark brown petrified wood; large percussion flake scars with feathered and hinged terminations cover both faces. Three bifaces (chert) appear to be heat treated. Sma11, thick bifaces resemble "Group I, Form 10" and to a lesser degree "Group I, Form 7" thick bifaces described by Lynn, Fox, and O'Ma17ey $(1977: 62,63,65)$.

A11 of these bifaces have edges which are battered at the loci of various flake detachments. In general, edges have a very angular appearance, especially where flakes were detached. This type of edge condition probably results from intentional flaking. However, minimal use-wear is evident on all specimens. The petrified wood specimen (an end fragment) exhibits primarily scalar scars and some step scars, all of which are abraded and appear to be well rounded. The wear pattern is intermittently unifacial, but alternates between faces. Another end fragment exhibits bifacial use-wear in the form of deep scalar and step scars which are slightly abraded. The pattern is rather continuous along lateral edges. The largest end fragment is made from a very fine grain, glossy (heat-treated) material and exhibits an extremely irregular edge. Most of the edge fails to show use-wear, but a few protrusions do exhibit unifacial scalar scars which are slightly abraded. This suggests that the tool has been resharpened. The remaining artifacts (two medial and one end fragment) exhibit mostly step scars but some scalar scars. The pattern is intermittent and unifacial. It is confined to one face of any given lateral edge, but tends to occur on alternate faces of the lateral edges. Size ranges are: width $30.25-36.00 \mathrm{~mm}$, thickness 12.35-21.50 mm.

Thin Bifaces ( 41 specimens; Table 12)

Wide (9 specimens)

These specimens are three pointed end or tip fragments (Fig. 9,s), three medial fragments (Fig. 9,r), and three square end or base fragments (Fig. 9,q). A11 specimens exhibit medial snaps or hinge fractures. These different fragment types are placed in one category because the biconvex cross section, thickness, and width of the specimens, as well as manufacturing technology, are similar. Field drawings of complete bifaces with similar characteristics indicate that these bifaces are basically triangular in plan view. Lateral edges are roughly paralle1, tapering rapidly to a point at one end, and contracting slightly to form the base end, which is straight to slightly concave. Edge angles are low. Specimens exhibit bifacial secondary trimming along most or all of the worked edges. Edges tend to be somewhat sinuous, indicating a lack of fine trimming. Secondary trimming was probably accomplished through percussion flaking, perhaps with a soft hammer. Cortex is not present on these bifaces. Six were heat treated. This type of biface occurred frequently at survey-recorded sites. Similar artifacts were observed at sites 41 LK 124, 41 LK 149, 41 LK 185, 41 LK 191, 41 LK 201, 41 MC 196, 41 MC 204, and 41 MC 226 (2 specimens). Wide, 
TABLE 12. THIN BIFACES

\begin{tabular}{|c|c|c|c|c|c|c|c|c|}
\hline Site Number & Wide & Trianguloid & $\begin{array}{c}\text { Trianguloid } \\
\text { beveled }\end{array}$ & Rectanguloid & Elongated & $\begin{array}{c}\text { Concave } \\
\text { base }\end{array}$ & $\begin{array}{c}\text { Rounded } \\
\text { end }\end{array}$ & $\begin{array}{c}\text { Pointed } \\
\text { end }\end{array}$ \\
\hline 41LK31 & & 1 & & & & & & \\
\hline $41 L K 32$ & 2 & 2 & & & & & & 1 \\
\hline \multicolumn{9}{|l|}{ 41LK121 } \\
\hline \multicolumn{9}{|l|}{ 41LK152 } \\
\hline 41LK159 & 2 & 1 & & & 1 & & 3 & 3 \\
\hline 41LK171 & 1 & 1 & 1 & & & & & \\
\hline 41LK181 & & 1 & 2 & & 2 & 1 & & 1 \\
\hline 41LK183 & & & & 1 & & & & \\
\hline \multicolumn{9}{|l|}{ 41МС199 } \\
\hline 41MC201 & 2 & 1 & 3 & & 2 & 1 & 1 & \\
\hline $41 M C 209$ & 2 & & & & & & & \\
\hline \multicolumn{9}{|l|}{$47 M C 210$} \\
\hline \multicolumn{9}{|l|}{$41 \mathrm{MC} 214$} \\
\hline \multicolumn{9}{|l|}{$41 \mathrm{MC} 217$} \\
\hline \multicolumn{9}{|l|}{$41 M C 225$} \\
\hline $\begin{array}{l}\text { Isolated } \\
\text { Find \#3 }\end{array}$ & & 1 & & & & & & \\
\hline
\end{tabular}


thin bifaces are almost identical to "Triangular, Form 7" and "Lanceolate, Form 1" bifaces described and illustrated by Lynn, Fox, and O'Malley (1977:72-75).

These bifaces exhibit similar use-wear, but it varies from minimal to extensive. In some cases the edge is highly abraded. While wear is present on both faces of the edge, it tends to be more evident on one face. It is interesting to note that musse1 shells occurred at most sites where this type of biface was observed; perhaps it was associated with processing freshwater mussels. Size ranges are: width $38.45-50.35 \mathrm{~mm}$, thickness $8.10-10.15 \mathrm{~mm}$.

\section{Trianguloid (8 specimens)}

This category contains fragments of thin bifaces (Fig. 10,d) which were probably triaguloid in plan view. Four of the specimens are obviously trianguloid and are missing one corner. Three items are tip end only and are placed in this category because they are technologically and morphologically similar to the specimens missing only one corner. The tip only specimens are larger than those that are more complete. One edge fragment is included for the same reason. Edges are convex to straight, and bases, when present, are straight to convex.

These bifaces are made on flakes as indicated by the curved (concave-convex) appearance of the longitudinal section, by the presence of large flake scars which could not have originated at the biface edge, and by the cross sections which tend to be plano-convex. Secondary flaking tends to occur on both faces, but two specimens exhibit secondary flaking on only one face. Edges tend to be relatively straight, but on those specimens with little secondary flaking, edges are sinuous. The edge angle is low. Flaking is by percussion and flake scars tend to have feathered terminations, but many exhibit hinge terminations. None of the items retains cortex. Seven specimens appear heat treated. Thin trianguloid bifaces approximate "Triangular, Form 1 " and "Pointed End Fragments" described by Lynn, Fox, and O'Malley (1977:74, 75, 83, 84). Similar specimens were also observed at sites 41 LK 133, 41 LK 158, 41 LK 166, 41 LK 173, 41 LK 176, and 41 LK 195.

Use-wear evident on thin triangular bifaces is varied. Two specimens exhibit use-wear similar to that of thin triangular beveled bifaces (see below), and a similar function is suggested. Two items (one with a corner missing, and the edge fragment) exhibit edges with scalar scars overlain by numerous step scars; abrasion is evident, but limited in scope. The pattern occurs along most of one face of the edge with the opposite face being abraded or rounded with an occasional scalar scar. All three tip only fragments exhibit usewear similar to that described above, but on both faces and intermittentiy along lateral edges. The remaining specimen (a corner missing item) exhibits intermittent scalar scars which are slightly abraded or rounded. Artifacts in this category are heterogeneous in morphology and perhaps even more so in function. Size ranges are: length 42.40-61.10 mm, width 28.00-48.00 mm, thickness $7.05-12.55 \mathrm{~mm}$, weight $8.5-19.9 \mathrm{gm}$. 


\section{Trianguloid Beveled (5 specimens)}

Bifaces (Fig. 10,a,b) in this category are generally termed Tortugas (Suhm and Jelks 1962:249-250). They are trianguloid in plan view and have straight to slightly convex edges. The base is also straight to slightly convex. Cross sections are biconvex, with the lateral edge characteristically exhibiting bifacial beveling. Maximum thickness is in the medial portion of the biface. Base ends are thinned and feathered (one specimen exhibits a bifacially beveled base; it may have been broken and subsequently resharpened). The tip end tends to be almost diamond shaped in cross section, and all tips are missing. Four of the specimens exhibit a hinge fracture as if the causal force came from the tip end. The fifth specimen exhibits a snap fracture. This suggests that the tip was subjected to extensive use and was often broken while in use. All items exhibit bifacial secondary trimming resulting in relatively straight as opposed to sinuous edges. In plan view the edges are uneven almost to the point of slight serrations. All appear heat treated. Similar specimens were observed at sites 41 LK 124 (2 specimens), 41 LK 139, and 41 LK 158.

A11 specimens in this category have readily evident use-wear. The use-wear is remarkably uniform among the specimens. Use-wear is bifacial and exhibits extensive step scars and scalar scars. Step scars are predominant on one face; scalar scars are predominant on the opposite face. Both types of scars occur on both faces and along the lateral edges from tip to base, being more concentrated near the tip. Scars are highly abraded, resulting in the very rounded appearance of the edge. Use-wear is heaviest on the protrusions, and the edge appears crushed at various places between protrusions. Use-wear is also evident on the base, but tends to appear as sporadic unifacial scalar scars. Size ranges are: length $37.00-58.00 \mathrm{~mm}$, width $22.70-31.40 \mathrm{~mm}$, thickness 7.25 $9.65 \mathrm{~mm}$, weight 5.9-13.6 gm.

\section{Rectanguloid (3 specimens)}

These bifaces (Fig. 10,C) are probably made on flakes, judging from the twisted appearance of one artifact and the plano-convex cross section of another. However, two specimens exhibit a biconvex cross section. A71 three specimens are end or base fragments, and all exhibit a hinged medial fracture. Lateral edges are relatively straight and contract slightly near the base. The basal edges are convex. Secondary flaking is apparent on all specimens and al1 exhibit some fine or tertiary, perhaps pressure flaking. As a result, edge angles are low, and edges tend to be relatively straight as opposed to sinuous. One specimen is of petrified wood. Two specimens (chert) are heat treated. Thin rectangular bifaces closely resemble "Triangular, Form 7" thin bifaces described by Lynn, Fox, and O'Ma11ey (1977:76-77).

Use-wear is evident on all specimens. It takes the form primarily of numerous scalar scars, occasionally overlain by step scars. Scars are abraded, especially on the small protrusions. The pattern is bifacial and relatively continuous along both lateral edges of all three bifaces. Two specimens exhibit the same bifacial wear on the base, but the petrified wood item exhibits only unifacial wear on its base. Similar specimens were observed at $41 \mathrm{LK} 182$ and $41 \mathrm{LK}$ 194. Size ranges are: width $23.25-31.10 \mathrm{~mm}$, thickness $6.10-8.20 \mathrm{~mm}$. 
Figure 10. Lithic Artifacts: Various Bifaces and Ground Stone. a, thin biface, trianguloid beveled, Tortugas-like; b, thin biface, trianguloid beveled, Tortugas-1ike; c, thin biface, rectanguloid; $d$, thin biface, trianguloid; e, thin biface, elongated, Specimens 1-2, Abasolo-like; $f$, thin biface, elongated, Specimens $3-4$, Desmuke-1ike; $g$, thin biface, elongated, Specimen 5, Refugio-1ike; $h$, thin biface, concave base, Plainview1ike; i, Dare; j, Edgewood/Ensor; k, Edgewood/Ensor; 1, Gary; m, Frio; $n$, Pedernales; 0 , Pedernales; $p$, Angostura; $q$, Perdiz; $r$, miscellaneous biface, Specimen 1; s, miscellaneous biface, Specimen 7; $t$, miscellaneous biface, Specimen 4; u, miscellaneous biface, Specimen 8; v, miscellaneous biface, Specimen 2; w, miscellaneous biface, Specimen 3; x, miscellaneous biface, Specimen $5 ; y$, miscellaneous biface, Specimen $6 ; z$, miscellaneous biface, Specimen 9; aa, miscellaneous biface, Specimen 10; bb, ground stone, grinding stone (mano); $c c$, ground stone, incised; dd, ground stone, grinding stone, incised; ee, ground stone, grinding stab (metate). 


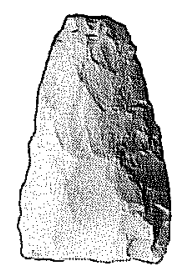

a

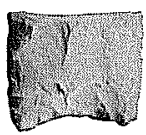

h

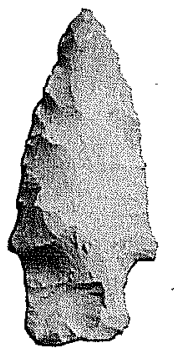

o

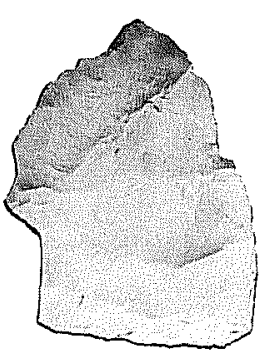

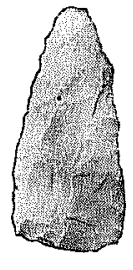

b

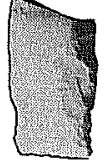

i

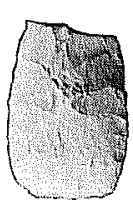

c

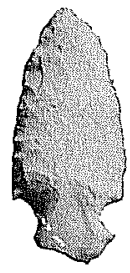

j

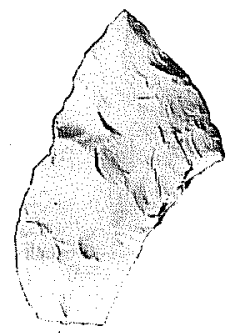

d

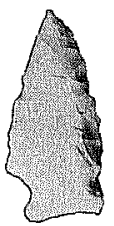

k

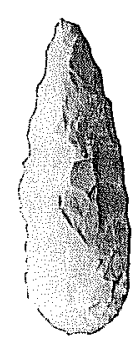

e

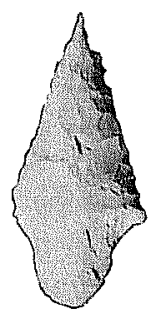

I

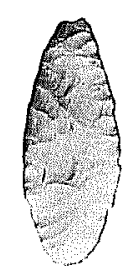

$f$

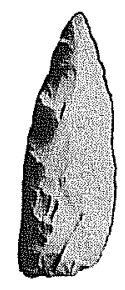

9
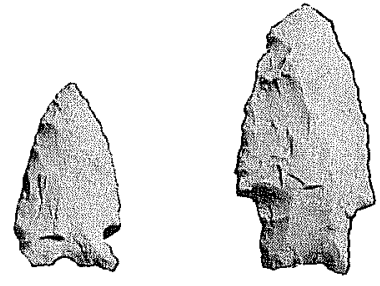

กา
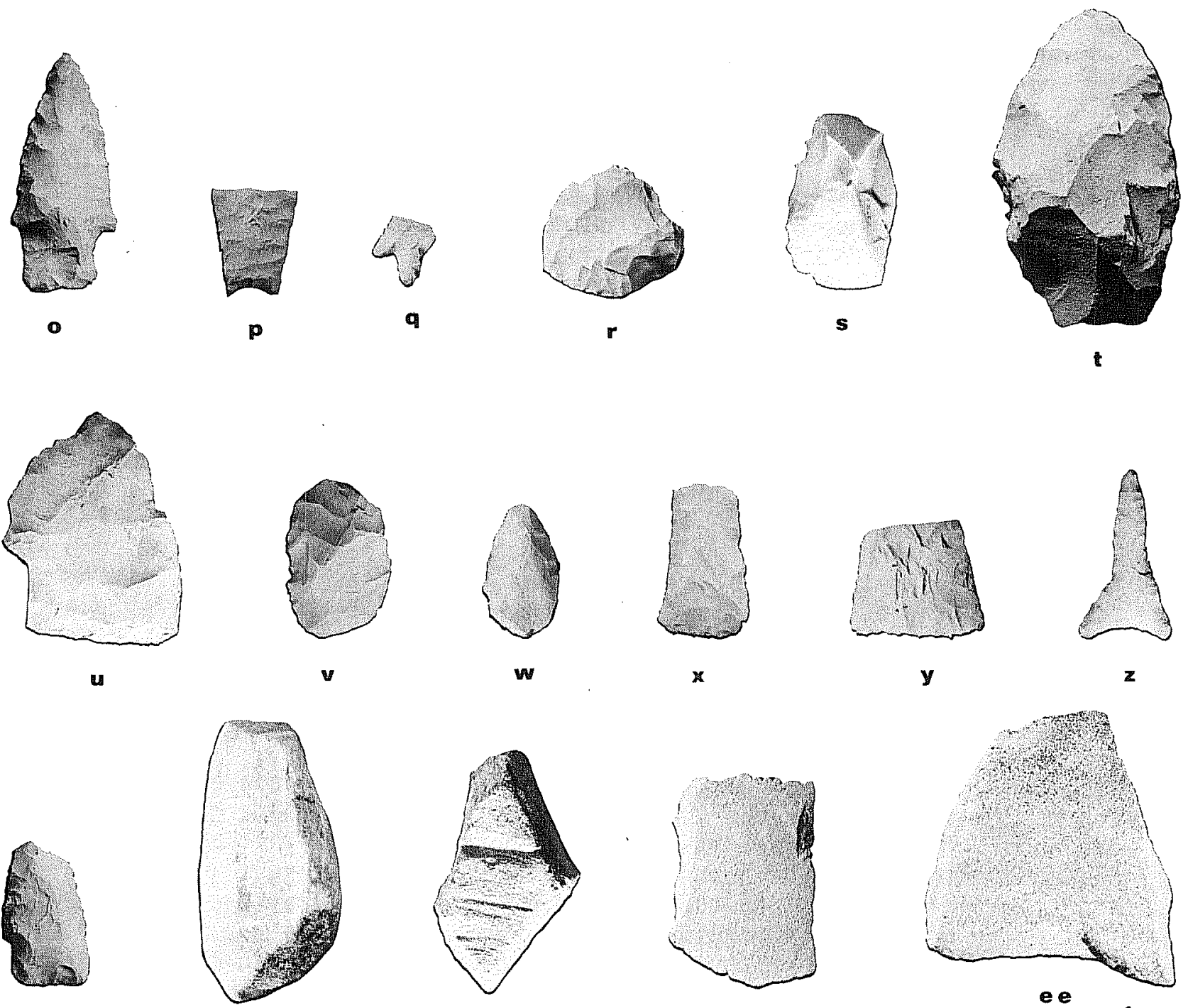

b b

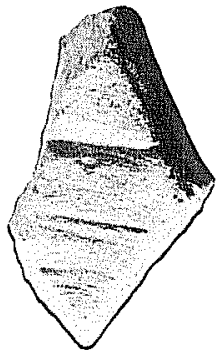

cc
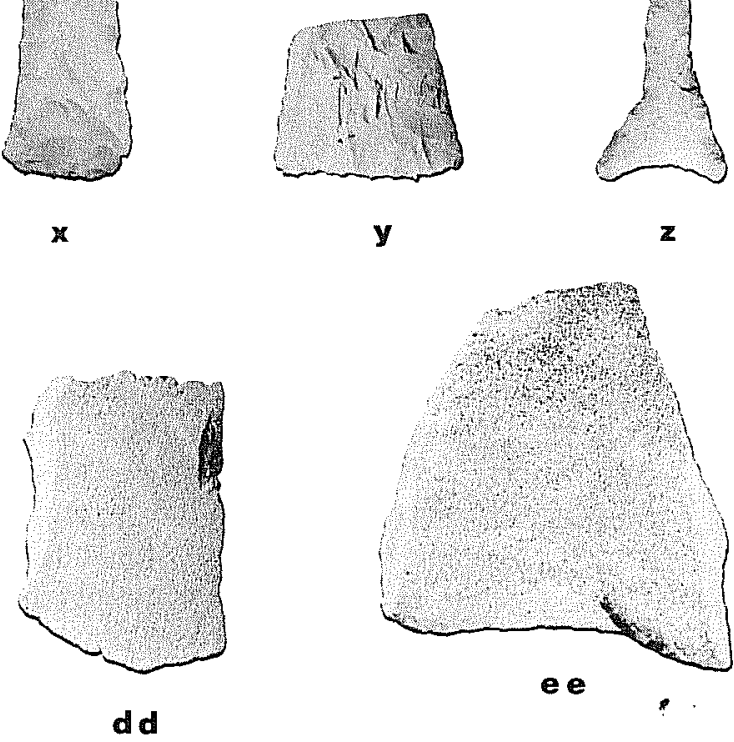

$\underbrace{0,1,1,15}$ 


\section{Elongated (5 specimens)}

Bifaces in this category are long and narrow. All exhibit a pointed end (tip) and a contracting base that is either pointed or very convex. Two similar specimens were observed at sites 41 LK 124 and 41 MC 213.

Specimens 1-2: These items (Fig. 10,e) appear to have been made on flakes, judging from the curved appearance of the longitudinal sections. In cross section they are biconvex, but one face is more convex than the other. Both exhibit secondary flaking. Most of the flaking is percussion, but some flake scars may be from pressure flaking. Edges retain a sinuous appearance. Flake scars exhibit feathered and hinge terminations. Flakes tend to terminate along the medial axis of both faces, resulting in a medial ridge on one face and an almost beveled appearance on the other face. Lateral edges are slightly convex and exhibit high edge angles. Both specimens exhibit markedly convex bases with edge angles smaller than those on the lateral edges. One lateral edge of the base is indented, giving the appearance of a slight single shoulder. These bifaces are like "Pointed/Ovate, Form $1 "$ thin bifaces described by Lynn, Fox, and $0^{\prime M a}$ Mley $(1977: 71,73)$ and, as they noted, the bifaces are also 1ike the Abasolo projectile point (Suhm and Jelks 1962:165-166).

Use-wear is not readily apparent on these specimens. Sizes are: length 53.40 and $64.75 \mathrm{~mm}$, width 20.50 and $22.15 \mathrm{~mm}$, thickness 9.30 and $12.60 \mathrm{~mm}$, weight 9.7 and $16.6 \mathrm{gm}$.

Specimens 3-4: These items (Fig. 10,f) appear to be made on flakes, judging from the curved appearance of the longitudinal sections. They are biconvex in cross section, with one face being more convex than the other. Both specimens exhibit fine pressure flaking which covers most of both faces. On one specimen, flake scars are parallel and extend from both edges to the medial axis. The edge angle is low and edges are sinuous. Both specimens have a contracting base which comes to a point on one specimen and is extremely convex on the other. The transition from blade to base is evident on both artifacts. Both appear heat treated. These bifaces are like "Contracting-Stem, Form 3" thin bifaces described by Lynn, Fox, and O'Malley $(1977: 76,79)$ and, as they noted, these bifaces are also like the Desmuke projectile point (Suhm and Jelks 1962:181-182).

Bifacial wear is heavy on the lateral edges of the blade portion of both artifacts. It takes the form of extensive and deep scalar scars overlain by step scars, with these scars and the edge of the bifaces being heavily abraded. In some places, the edge appears crushed. The pattern is relatively continuous along the entire edge, but is heaviest near the tip end. Sizes are: length 40.20 and $54.00 \mathrm{~mm}$, width 19.05 and $20.40 \mathrm{~mm}$, thickness 6.50 and $6.85 \mathrm{~mm}$, weight 5.4 and $7.5 \mathrm{gm}$.

Specimen 5: This specimen (Fig. 10,g) is markedly plano-convex in both sections and was made on a flake, as is indicated by portions of a large flake scar on one face. The convex face is beveled on both edges and the base is thinned. Blade edge angles are high and the base has a low edge angle. Secondary percussion flaking is evident on the convex face as is some pressure flaking. The flat faces exhibit only marginal trimming except near the tip where flake scars cover the entire face. Edges are slightly more sinuous than those of Specimens 3 and 4 . The specimen appears heat treated. This specimen resembles the 
"Pointed/Ovate, Form 2" thin biface described by Lynn, Fox, and 0'Malley (1977: $71,73)$. As these authors noted, such bifaces are similar to the Refugio projectile point (Suhm and Jelks 1962:241-242).

Use-wear on the lateral edges is like that on Specimens 3 and 4 and a similar function is suggested. However, the tip end is extremely abraded, and step scars are confined to both edges of one face. This pattern does not conform to any type of action described by Tringham et al. (1974), but it does suggest dri11 wear to us. Size is: length $54.30 \mathrm{~mm}$, width $19.10 \mathrm{~mm}$, thickness $7.25 \mathrm{~mm}$, weight $8.7 \mathrm{gm}$.

Concave Base (2 specimens)

These two items (Fig. 10,h) consist of base ends only and exhibit medial hinge fractures. Cross sections are biconvex. One specimen is made from common grainy brown chert, and the other is from a fine-grained brown chert which appears heat treated. The faces of both artifacts exhibit evidence of secondary percussion flaking and some pressure flaking. Flake scars exhibit mostly feathered terminations but some are hinged. Lateral edges are straight and basically parallel. The base is concave. All flaked edges are relatively straight as opposed to sinuous and edge angles are low. Basal thinning is evident on both specimens. The specimens are similar in shape to Plainview projectile points (Suhm and Jelks 1962:240-241). Both specimens evidence some grinding of the lateral edges near the base, a trait which is characteristic of Plainview points. In general, flaking is rougher than that associated with Plainview points.

As stated above, both specimens evidenced some edge grinding, but it is more evident on the specimen made of common grainy brown chert. In general, the edge damage is bifacial and well-worn step scars predominate. In addition to the bifacial wear, the specimen made from fine-grained brown chert exhibits unifacial step scars on alternate faces near the break. The step scars and the biface edge are wel1 rounded. Sizes are: width 27.35 and $27.60 \mathrm{~mm}$, thickness 6.05 and $8.05 \mathrm{~mm}$.

\section{Rounded End (4 specimens)}

This is a catcha11 category for smal1 rounded end fragments of thin bifaces of unknown shape. Similar specimens were observed at 41 LK 133, 41 LK 144, 41 MC 203, and 41 MC 205. Two exhibit snap fractures and two are hinge fractured. Three are made from common brown grainy chert, and one is from a pink fine-grained chert that is heat treated. Manufacture is by percussion. Three of the specimens have relatively straight edges, suggesting secondary flaking; one specimen exhibits sinuous edges. The edge angles tend to be low.

One specimen exhibits primarily unifacial use-wear in the form of scalar scars overlain by step scars, both of which are well rounded. The other three artifacts exhibit a similar wear pattern, but one which is bifacial; abrasion or rounding of the flake scars and edges is more evident. 


\section{Pointed End (5 specimens)}

This category is a residual one for the pointed ends of thin bifaces. All items exhibit a medial hinge or snap fracture. These artifacts probably represent the tip ends of artifacts commonly considered to be projectile points. One of the specimens was broken in such a manner as to have removed only the stem, leaving the entire blade. The base end retains evidence of notching at both corners. Two artifacts are made from common grainy brown chert, one is from a fine-grained brown chert that appears heat treated, another is from a very red grainy chert which appears heat treated, and the remaining one is from a very fine-grained-translucent white chertlike material. All items exhibit secondary percussion flaking over most of both faces, and two have smal1 flake scars that are probably the result of pressure flaking. Two specimens exhibit alternately beveled edges, and one is beveled or at least steeply trimmed on both edges of one face. These items are biconvex in cross section and have a high edge angle. The other two specimens are also biconvex in cross section, but one face is more convex than the other. They have low edge angles.

One specimen exhibits use-wear primarily in the form of scalar scars that are removed bifacially at high angles. Some flake scars are overlain by step scars. Abrasion is minimal. Use-wear occurs intermittently along most of both edges, but is most apparent near the medial fracture. Cutting of medium or hard materials is the suggested function. Use-wear on another specimen takes the form of a well-abraded edge and an occasional scalar scar, with abraded areas being more concentrated on one face than the other. Large step scars also occur adjacent to edges but seem to be the result of deliberate attempts to remove flakes. Use-wear suggests longitudinal action on medium or soft materials, with the tool being held at an angle (about $90^{\circ}$ ) to the surface being cut. The three specimens with beveled edges exhibit similar use-wear, which takes the form of steep step scars and some scalar scars concentrated on the beveled face; some abrading is noted near the edge; the opposite face is more abraded. Only one specimen exhibits this pattern on the tip end.

\section{Projectile Pointlike Bifaces (10 specimens; Table 13)}

Chipped stone artifacts which are thought to have been attached to the end of shafts and intended to pierce and dispatch prey when projected have been termed arrowheads (Wi1son 1898), arrow points, and spearheads (ibid.). By convention, the above artifacts are now most commonly referred to as projectile points. From a morphological standpoint, the term projectile point has been defined as "a bilaterally symmetrical, bifacially flaked stone tool consisting of two distinct parts: a distally pointed blade, and a haft element usually distinguished from the blade, by its assumed preparation for hafting by means of edge grinding, notching, lateral constriction or other modification" (Ahler $1971: 6)$. Despite the fact that there are "those artifacts which an archeologist would consistently classify as 'projectile points' on the basis of size and shape" (ibid.), there are also questionable artifacts. For example, it has been noted of Kinney points that "it is quite possible that the longest and broadest specimens (or even all of them) are knives rather than projectile points" (Suhm and Jelks 1962:201). These questionable artifacts are those which lack notching, stems, or obvious basal grinding (such as that which occurs on Paleo-Indian points). They were described in earlier sections of this chapter and include Abasolo, Desmuke, Plainview, Refugio, and Tortugas. 
TABLE 13. PROJECTILE POINTLIKE AND MISCELLANEOUS BIFACES

$41 L K 121$

$47 L K 152$

$A, B$

$41 L K 159$

1 Edgewood/Ensor

$412 K 171$

1 Edgewood/Ensor

E

$41 L K 181$

1 Frio, 1 Gary, 1 Perdiz

$41 L K 183$

$41 M C 199$

$41 \mathrm{MC} 201$

1 Pedernales

F, I

$41 M C 209$

1 Dare, 1 Pedernales

C, G

$41 M C 210$

$41 \mathrm{MC} 214$

1 Angostura

$41 \mathrm{MC} 217$

$41 M C 225$

Isolated Find \#2 
Bifaces which are notched, stemmed, or exhibit obvious basal grinding are termed projectile points, and are briefly described as being like established projectile point types, i.e., Pedernales-7ike or Angostura-like. It should also be noted that we use the term projectile point in a descriptive sense (as opposed to functional) in the same manner as we employ the term thin triangular biface. As previously noted, this is what we mean whenever we use type names in this report, although names are usually given without the "-like" appendage.

\section{Dare ( 1 specimen)}

This specimen (Fig. 10,i) easily fits the description of the Dare point (Suhm and Jelks 1962:179-188). The right edge of both faces is beveled, slight shoulders are present, and the stem is parallel sided. The specimen is made from a fine-grained reddish brown, heat-treated chert and is missing the distal end of the blade. Use-wear is evident on the blade portion only. It takes the form of numerous we11-abraded step scars that appear to be confined primarily to the edge and a small portion of the beveled face. Abrasion is apparent on the extreme perimeter of both faces, but more so on the edge of the biface, especially on small protrusions. This wear pattern is similar to that produced by intentional grinding of the edge as if to prepare the edge for additional flaking (Sheets 1973:217-218). It also resembles use-wear rsulting from scraping bone or antler (Tringham et al. 1974:191). The specimen is from site $41 \mathrm{MC} 209$. Size is: maximum width $17.9 \mathrm{~mm}$; minimum stem width $15.2 \mathrm{~mm}$ (length and weight not given due to incompleteness).

\section{Edgewood/Ensor (3 specimens)}

These specimens (Fig. 10,j,k) exhibit mixed characteristics similar to both Edgewood and Ensor types and, as has been noted, these two types could be combined (Suhm and Jelks 1962:183-184, 189-190). One specimen is made from a light gray grainy chert. It is wide and thin, with convex edges which have an almost serrated appearance. Both basal corners are missing. Use-wear is bifacial and consists primarily of abrasions; the tip is especially well rounded. This specimen if from 41 LK 171 and measures $46 \mathrm{~mm}$ in length, $29 \mathrm{~mm}$ in maximum width, $21.5 \mathrm{~mm}$ in minimum step width, and $6.55 \mathrm{~mm}$ in thickness; it weighs $9.4 \mathrm{gm}$.

One specimen ( $F i g .10, j$ ) is made from a light gray fine-grained chert. A11 four lateral edges are steeply trimmed, resulting in a beveled appearance. One lateral edge appears to have been broken and reworked. The edge condition is like that of the Darl projectile point. This specimen is an isolated find (number I-4). Size is: Tength $42.2 \mathrm{~mm}$, maximum width 19.75, minimum stem width $13.25 \mathrm{~mm}$, thickness $7.6 \mathrm{~mm}$, weight $6.7 \mathrm{gm}$.

One specimen (Fig. $10, k$ ) is made from a fine-grained pink chert that was probably heat treated. It is biconvex in cross section with a relatively high edge angle. The blade edges are convex and finely serrated. Use-wear is not readily observable. Edges are clean and sharp in appearance; the tool was probably not used after the edge was serrated. The specimen is from 41 LK 59. Size is: length $52 \mathrm{~mm}$, maximum width $23.45 \mathrm{~mm}$, minimum stem width $13.05 \mathrm{~mm}$, weight $10.0 \mathrm{gm}$.

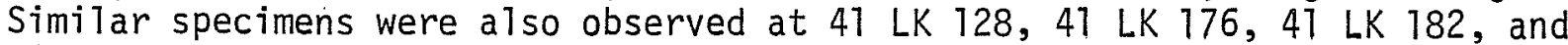
41 LK 187. 
Gary ( 1 specimen)

This specimen (Fig. 10,1) easity fits the description of the Gary point (Suhm and Jelks 1962:197-198) although it is well beyond the geographical range of the type. It is made from the common grainy brown chert. Edge use-wear is not readily evident on most of the blade. Rather, edges are clean and sharp in appearance as if the tool had not been used. However, the tip does exhibit use-wear in the form of many small step scars that are primarily unifacial on one edge and bifacial on the other edge. The scars, faces, edges, and tip are well abraded. This type of use-wear is similar to that resulting from boring (drilling) action, but striations were not noted (Tringham et al. 1974:188, 192). The specimen is from site 41 LK 181. Size is: length $58.90 \mathrm{~mm}$, maximum width $27.70 \mathrm{~mm}$, minimum stem width $15.5 \mathrm{~mm}$, thickness $7 \mathrm{~mm}$, weight $9.0 \mathrm{gm}$. It is very similar to the "Contracting-Stem, Form 4, Thin Biface" described by Lynn, Fox, and O'Ma11ey (1977:78-79).

\section{Frio (1 specimen)}

This specimen (Fig. 10,m) is like the Frio point as described by Suhm and Jelks (1962:195-196), including the U-shaped notch in the center of the base. It is - made from a fine-grained pinkish chert which is probably heat treated. One corner of the base is missing. Use-wear is present on the blade edges in the form of well-abraded step and scalar scars distributed evenly along the edge. Abrasion increases near the tip. The pattern of use-wear is bifacial along one edge and unifacial on the other. This specimen is from 41 LK 181. Size is: length $38.15 \mathrm{~mm}$, maximum width $22.15 \mathrm{~mm}$, minimum stem width $17.25 \mathrm{~mm}$, thickness $6.2 \mathrm{~mm}$, weight $5.5 \mathrm{gm}$.

\section{Pedernales (2 specimens)}

These specimens (Fig. 10, $n, 0$ ) most closely resemble the Pedernales point described by Suhm and Jelks (1962:235-236). One specimen (Fig. 10,n) is made from a fine-grained gray chert. Both the lateral and basal edges appear to be ground, as described by Ahler (1971:39). Use-wear is readily observable on only one lateral edge of the blade. It takes the form primarily of steep scalar scars, some of which are overlain by step scars on one face. This specimen is from $41 \mathrm{MC} 209$. Size is: length $55.05 \mathrm{~mm}$, maximum width $28.1 \mathrm{~mm}$, minimum stem width 17.95, thickness $8.1 \mathrm{~mm}$, weight $11.3 \mathrm{gm}$.

The second specimen (Fig. 10,0) is complete and made from a reddish brown medium-grained quartzitelike material that was probably heat treated. Grinding of the stem edges is not evident on this specimen, and it is markedly biconvex in cross section. Use-wear is not readily observable on this item. It is from the excavated hearth at site $41 \mathrm{LK} 201$. Size is: length $66.95 \mathrm{~mm}$, maximum width $29.8 \mathrm{~mm}$, minimum stem width $21.4 \mathrm{~mm}$, thickness $11.95 \mathrm{~mm}$, weight $20.2 \mathrm{gm}$. A similar specimen was also observed at 41 MC 203.

\section{Angostura (1 specimen)}

This specimen (Fig. 10,p) is the base end of an Angostura point as described by Suhm and Jelks (1962:167-168). It is made from a very fine-grained gray 
chert. Lateral and basal edges of the base have been ground. Flaking is predominantly in the form of bifacial, parallel flake scars which meet along the medial axis. The specimen was collected from the backdirt of an animal burrow at site 41 MC 274. Size is: width at the fracture $24.55 \mathrm{~mm}$, width at the base $15.10 \mathrm{~mm}$, thickness at the fracture $5.5 \mathrm{~mm}$.

\section{Perdiz (1 specimen)}

This Perdiz arrow point (Suhm and Jelks 1962:283-284) is made from a fine-grained tan chert and is missing one barb and most of the blade (Fig. 10,q). The specimen is one of the two obvious arrow points recorded or collected during the survey and it is from site 41 LK 181. Minimum stem width is the only complete measurement and is $6.35 \mathrm{~mm}$. A Scallorn point was observed at $41 \mathrm{LK} 128$.

\section{Miscellaneous Bifaces (10 specimens; Table 13)}

Items in this category are similar only in that they are bifacially flaked and do not readily fit into one of the other categories. They are individually described.

Specimen 1: This artifact (Fig. 10,r) appears to be made on a large flake, and some percussion flake scars are evident on both faces. It is circular in shape and made from a fine-grained gray chert. Its surfaces are lightly patinated and no cortex remains. It is plano-convex in cross section. Pressure flakes have been unifacially removed from portions of one edge. Edges are relatively straight and the edge angle is low. Use-wear is evident on the one edge exhibiting pressure flaking. It is bifacial and has steep scalar and step fractures which are extremely abraded. Step scars are predominant on one face. The edge is abraded and a few areas have a crushed appearance. This specimen was collected from site 41 LK 159. Size is: length $42.55 \mathrm{~mm}$, width $36.9 \mathrm{~mm}$, thickness $8.7 \mathrm{~mm}$, weight $15.1 \mathrm{gm}$.

Specimen 2: This is a small oval biface (Fig. 10,v) made from a fine-grained light brown chert. Both faces are covered with short percussion flake scars which result in relatively thin edges with a much thicker midportion. The edge on one side of the medial axis is very sinuous and the other edge is rather straight. The specimen is complete except for a small portion of one end which exhibits a hinge fracture. Use-wear, other than slight edge abrasion, is not readily evident on this artifact; it may be an exhausted bifacial core. The artifact is from site 41 LK 159. Size is: 1ength $47.15 \mathrm{~mm}$, width $31.0 \mathrm{~mm}$, thickness $13.35 \mathrm{~mm}$, weight $18.7 \mathrm{gm}$. A similar artifact was observed at 41 MC 196 .

Specimen 3: This biface (Fig. 10,w) is tear shaped and made on a flake of a light gray translucent chertlike material. One face is incompletely covered with percussion flake scars. The tip and one edge of the other face exhibit percussion flake scars. Some pressure flakes were also removed from both faces. The edge angle is low and the cross section is plano-convex. The specimen is complete. Bifacial use-wear is evident on all edges except the base. It takes the form of relatively continuous scalar scars, a few of which are overlain by step scars present in about equal numbers on both faces. The artifact is from site $41 \mathrm{MC}$ 209. Size is: length $38.2 \mathrm{~mm}$, width $21.7 \mathrm{~mm}$, thickness $7.2 \mathrm{~mm}$, 
weight $5.7 \mathrm{gm}$. Similar specimens were observed at sites 41 MC 209, 41 LK 185 (2 specimens), and 41 LK 191.

Specimen 4: Percussion flaking has removed all cortex on this thick oval biface (Fig. 10,t) made from the common grainy brown chert. The artifact is biconvex in cross section. The edge angle is relatively high and edges are sinuous. This specimen is similar to the rounded end, thick bifaces, specimens 1-2 and Specimens 10-11, except that the base (blunt end) is unifacially, not bifacially, flaked. Use-wear takes the form of scalar scars, some of which are overlain by step scars. These scars are distributed along both edges but are more evident in some areas. Both the scars and the biface edge are abraded. The pattern is unifacial on one lateral edge and bifacial on the other lateral edge. Use-wear was not noted on the base edge. This specimen is from site 41 LK 32. Size is: length $88.2 \mathrm{~mm}$, width $50.6 \mathrm{~mm}$, thickness $27.5 \mathrm{~mm}$, weight $112.3 \mathrm{gm}$.

Specimen 5: The artifact (Fig. 10, $x$ ) is rectanguloid in shape and made from a fine-grained brown chert. It is incomplete, missing what was probably the tip. The medial fracture is hinged. Both percussion and pressure flakes are evident. The base end is thinned, but the artifact thickens abruptly and the blade portion is beveled from both edges on one face; the other face is flat. The artifact is markedly plano-convex in cross section. Edges are straight as opposed to sinuous. One lateral edge is straight in plan view, and the other is concave; the base is convex. Use-wear is evident on the lateral edge and on the base edge. Both edges of the beveled face exhibit extensive, steep scalar scars, some of which are overlain by step scars. Abrasion is also extensive on the scars and on the edge. Lateral edges of the flat face are also well abraded and exhibit an occasional scalar scar. The base end exhibits bifacial wear primarily in the form of steep scalar scars that are equally distributed on both faces. The scars and the edge are well abraded. This type of wear pattern suggests that the lateral edges were subject to transverse action such as scraping and the base edge was used to cut. The specimen is from site 41 LK 181 . Size is: length incomplete, width $26.8 \mathrm{~mm}$, thickness $9.3 \mathrm{~mm}$, weight $12.8 \mathrm{gm}$.

Specimen 6: This artifact (Fig. 10,y) is the base end of a probable triangularshaped thin biface. The medial fracture is hinged. It differs from thin trianguloid bifaces in that it exhibits extensive pressure flaking, especially on one face. It is made from a fine-grained dark brown chert that may be heat treated. Edges are straight as opposed to sinuous. The edge angle is low and the artifact has a biconvex cross section. In plan view all edges are straight. Use-wear is not readily evident on this specimen. The edge is extremely angular in appearance, and this damage may have occurred during final trimming. This specimen is from site $41 \mathrm{MC} 201$. Size is: length incomplete, width $38.35 \mathrm{~mm}$, thickness $9.3 \mathrm{~mm}$, weight $10.0 \mathrm{gm}$.

Specimen 7: This specimen (Fig. 10,s) is a squarish corner fragment of what was probably a large thick biface. The specimen exhibits one hinge and one snap fracture. It is made from a fine-grained brown chert that may have been heat treated. Percussion flaking has produced relatively straight edges with a high angle. The specimen has a biconvex cross section. One edge is slightly convex in plan view; the other is straight. Use-wear is apparent on both flaked edges. This specimen is from site 41 MC 209. A11 measurements are of incomplete dimensions: length $32.45 \mathrm{~mm}$, width $49.8 \mathrm{~mm}$, thickness $19.5 \mathrm{~mm}$, weight $30.39 \mathrm{gm}$. 
Specimen 8: A large trianguloid specimen (Fig. 10,u) with portions of both corners missing is made from a fine-grained dark brown chert that was heat treated. One face exhibits short secondary percussion flake scars which extend from one edge to the other. The specimen exhibits rather low edge angles and is biconvex in cross section. Use-wear is not apparent on this specimen. Rather, the face near the edge of the side exhibiting smaller flake scars is very angular, and the opposite face near the edge lacks damage except at the negative bulb. This pattern is probably the result of the manufacturing process. The artifact is from site $41 \mathrm{LK} 31$. Size is: length $66.25 \mathrm{~mm}$, width (incomplete) $51.45 \mathrm{~mm}$, thickness $15.25 \mathrm{~mm}$, weight $51.9 \mathrm{gm}$. Similar bifaces were observed at sites 41 LK 31, 41 LK 132, and 41 LK 199.

Specimen 9: This is a complete T-shaped drill (Fig. 10,z) made from a finegrained pink chert that was heat treated. Edges are bifacially worked, as indicated by the presence of small flake scars. The base end is biconvex in cross section and exhibits a low edge angle. The blade or bit is diamond shaped in cross section and thus exhibits a high edge angle. Use-wear is most apparent on the bit, where highly abraded unifacial step scars occur on opposite edges but alternate faces. Near the tip, the pattern changes and step scars occur on both edges of one face. Heavy abrasion is present not only on edges but also on both faces of the bit. Some abrasion is also present on the edges and face of the base end. It seems that this tool may have been used as a perforator. The specimen was collected from site $41 \mathrm{MC} 201$. Size is: length $50.65 \mathrm{~mm}$, width at base $27.65 \mathrm{~mm}$, width midway on the bit $9.6 \mathrm{~mm}$, thickness $6.10 \mathrm{~mm}$, weight $5.5 \mathrm{gm}$.

Specimen 10: This artifact (Fig. 10,aa) is probably the base end of a projectile point which has been reworked along one lateral edge and along the end of the blade portion. It is made from a fine-grained tan chert. The stem appears to have been large and rectangular with a slight shoulder. The shouldered side of the artifact exhibits both percussion and pressure flake scars. The reworked edge exhibits percussion flake scars and is more sinuous than the other edge. Use-wear is not readily evident on the lateral edges or the base. The reworked blade end exhibits numerous scalar scars and an abraded edge. The item is an isolated find (number 2). Size is: length $42.2 \mathrm{~mm}$, width $23.45 \mathrm{~mm}$, thickness $7.05 \mathrm{~mm}$, weight $8.4 \mathrm{gm}$.

\section{DEBITAGE}

Flakes ( 571 specimens; Tables 14*, 15*)

The reduction of isotropic lithic materials by the application of force produces several kinds of debitage. Flakes are one of the most important kinds of debitage, and they can be recognized by numerous characteristics. On the dorsal (outer) surface, flakes can retain cortex and/or scars of previous flake removals (Chapman 1973:311). The ventral (inner) face, which originates from the interior of the core, usually exhibits a smooth surface, positive bulb of force, ripples (or "conchi"), the remnant of a striking platform, and force striations (cf. Chapman 1973; Speth 1972; Schaafsma 1977). The proximal end of the flake is the end that received the force and has the striking platform. Ventral ripple lines radiate outward from the flake's proximal end. Detailed 
TABLE 14. FLAKES*

Flakes were not collected from $41 \mathrm{MC} 209$ and $41 \mathrm{MC} 214$.

\begin{tabular}{|c|c|c|c|c|c|c|c|c|c|c|c|c|c|c|c|}
\hline \multirow{2}{*}{$\begin{array}{l}\text { Site } \\
\text { Number } \\
41 \text { LK31 }\end{array}$} & \multirow{2}{*}{$\begin{array}{c}\begin{array}{c}\text { Total } \\
\text { Number } \\
\text { of } \\
\text { Flakes }\end{array} \\
39\end{array}$} & FLK & $\begin{array}{l}\text { Tec } \\
\text { BFK }\end{array}$ & $\begin{array}{l}\text { ype } \\
\text { LD }\end{array}$ & PFK & IND & 6 & 5 & $\begin{array}{l}\mathrm{Siz} \\
4\end{array}$ & 3 & 2 & 1 & & $\begin{array}{l}17 \mathrm{~S} \\
2\end{array}$ & $\begin{array}{c}\text { Irface } \\
3\end{array}$ \\
\hline & & 26 & 8 & 3 & 2 & 0 & 0 & 1 & 4 & 22 & 12 & 0 & 0 & 22 & 17 \\
\hline $41 L \dot{K} 32$ & 102 & 71 & 23 & 4 & 4 & 0 & 0 & 1 & 5 & 64 & 32 & 0 & 1 & 40 & 61 \\
\hline $41 L K 121$ & 7 & 6 & 1 & 0 & 0 & 0 & 0 & 0 & 0 & 2 & 5 & 0 & 2 & 4 & 1 \\
\hline 41LK152 & 22 & 21 & 0 & 1 & 0 & 0 & 0 & 0 & 0 & 5 & 14 & 3 & 3 & 16 & 3 \\
\hline $41 L K 159$ & 63 & 38 & 17 & 0 & 8 & 0 & 0 & 3 & 28 & 32 & 0 & 0 & 1 & 25 & 37 \\
\hline $41 L K 171$ & 18 & 12 & 4 & 0 & 2 & 0 & 0 & 1 & 1 & 9 & 7 & 0 & 0 & 8 & 10 \\
\hline $41 L K 181$ & 35 & 30 & 5 & 0 & 0 & 0 & 0 & 0 & 4 & 24 & 7 & 0 & 2 & 19 & 14 \\
\hline 41 LK183 & 8 & 4 & 3 & 0 & 1 & 0 & 0 & 0 & 0 & 5 & 3 & 0 & 1 & 4 & 3 \\
\hline 41 MC199 & 7 & 7 & 0 & 0 & 0 & 0 & 0 & 0 & 1 & 5 & 1 & 0 & 3 & 3 & 1 \\
\hline $41 M C 201$ & 240 & 160 & 56 & 4 & 19 & 1 & 0 & 6 & 69 & 135 & 29 & 1 & 4 & 98 & 138 \\
\hline $41 M C 210$ & 15 & 14 & 0 & 0 & 1 & 0 & 0 & 1 & 1 & 9 & 4 & 0 & 3 & 9 & 3 \\
\hline $41 M C 217$ & 7 & 5 & 1 & 1 & 0 & 0 & 0 & 0 & 3 & 2 & 2 & 0 & 1 & 2 & 4 \\
\hline $41 M C 225$ & 8 & 3 & 1 & 0 & 4 & 0 & 0 & 0 & 5 & 2 & 1 & 0 & 0 & 2 & 6 \\
\hline
\end{tabular}


TABLE 14. (continued)

\begin{tabular}{|c|c|c|c|c|c|c|c|c|c|c|c|c|c|c|c|c|}
\hline $\begin{array}{l}\text { Site } \\
\text { Number }\end{array}$ & CT & $\begin{array}{r}\text { P1 } \\
\text { ST }\end{array}$ & $\begin{array}{c}\text { tform } \\
\text { MT }\end{array}$ & $\begin{array}{c}\text { Prepo } \\
\text { GD }\end{array}$ & $\begin{array}{r}\text { tion } \\
\text { CRS } \\
\end{array}$ & IND & FLT & $\begin{array}{l}\text { tfor } \\
\text { CRV } \\
\end{array}$ & $\begin{array}{r}\text { hape } \\
\text { TRI } \\
\end{array}$ & IND & FET & $\begin{array}{l}\text { Flak } \\
\text { RUN }\end{array}$ & $\begin{array}{l}\text { Term } \\
\text { FLT }\end{array}$ & $\begin{array}{l}\text { natiol } \\
\text { STE }\end{array}$ & ZTE & IND \\
\hline 41LK31 & 9 & 9 & 14 & 1 & 5 & 1 & 15 & 11 & 12 & 1 & 18 & 0 & 11 & 6 & 1 & 3 \\
\hline 41LK32 & 14 & 28 & 51 & 0 & 8 & 1 & 34 & 15 & 52 & 1 & 55 & 0 & 19 & 15 & 10 & 3 \\
\hline 41LK1 21 & 2 & 3 & 2 & 0 & 0 & 0 & 6 & 0 & 1 & 0 & 2 & 0 & 1 & 3 & 1 & 0 \\
\hline $47 L K 152$ & 7 & 7 & 4 & 0 & 4 & 0 & 16 & 2 & 3 & 1 & 8 & 0 & 5 & 6 & 2 & 1 \\
\hline 41LK159 & 6 & 14 & 35 & 0 & 8 & 0 & 21 & 8 & 34 & 0 & 24 & 0 & 20 & 7 & 9 & 3 \\
\hline 41LK171 & 2 & 4 & 10 & 1 & 1 & 0 & 10 & 3 & 5 & 0 & 3 & 0 & 8 & 4 & 2 & 1 \\
\hline 41LKlöl & 11 & 11 & 12 & 0 & 0 & 1 & 23 & 1 & 10 & 1 & 13 & 1 & 11 & 5 & 2 & 3 \\
\hline 41LK183 & 1 & 4 & 3 & 0 & 0 & 0 & 4 & 1 & 3 & 0 & 5 & 1 & 1 & 1 & 0 & 0 \\
\hline $41 M C 199$ & 4 & 2 & 1 & 0 & 0 & 0 & 4 & 1 & 1 & 1 & 3 & 0 & 2 & 1 & 1 & 0 \\
\hline $41 M C 201$ & 36 & 56 & 123 & 3 & 18 & 4 & 107 & 26 & 99 & 8 & 79 & 3 & 80 & 38 & 29 & 11 \\
\hline $47 M C 210$ & 3 & 3 & 6 & 0 & 3 & 0 & 6 & 4 & 5 & 0 & 4 & 1 & 2 & 7 & 0 & 1 \\
\hline $41 M C 217$ & 0 & 2 & 4 & 0 & 1 & 0 & 3 & 1 & 3 & 0 & 5 & 0 & 0 & 1 & 0 & 1 \\
\hline $47 M C 225$ & 0 & 2 & 6 & 0 & 0 & 0 & 4 & 1 & 3 & 0 & 2 & 0 & 1 & 2 & 1 & 2 \\
\hline
\end{tabular}


TABLE 14. (continued)

\begin{tabular}{|c|c|c|c|c|c|c|c|c|c|}
\hline $\begin{array}{l}\text { Site } \\
\text { Number }\end{array}$ & $\mathrm{FGC}$ & $\mathrm{CBC}$ & $\begin{array}{c}\text { Mater } \\
\text { CGC }\end{array}$ & 1 WTC & PTW & QTZ & OTH & $\begin{array}{l}\text { Heat } \\
\text { Treatment }\end{array}$ & Complete \\
\hline 41LK31 & 14 & 25 & 0 & 0 & 0 & 0 & 0 & 10 & 14 \\
\hline $41 L K 32$ & 41 & 53 & 6 & 0 & 2 & 0 & 0 & 21 & 55 \\
\hline $41 L K 121$ & 3 & 3 & 0 & 0 & 0 & 0 & 1 & 1 & 1 \\
\hline 41LK 152 & 8 & 11 & 0 & 0 & 0 & 1 & 2 & 6 & 7 \\
\hline 41LK159 & 30 & 31 & 1 & 0 & 1 & 0 & 0 & 19 & 17 \\
\hline $41 L K 171$ & 10 & 8 & 0 & 0 & 0 & 0 & 0 & 3 & 4 \\
\hline 41LK181 & 17 & 11 & 2 & 3 & 2 & 0 & 0 & 8 & 11 \\
\hline $41 L K 183$ & 3 & 4 & 0 & 1 & 0 & 0 & 0 & 1 & 3 \\
\hline $41 M C 199$ & 5 & 0 & 1 & 0 & 1 & 0 & 0 & 2 & 1 \\
\hline $41 M C 201$ & 121 & 106 & 5 & 0 & 4 & 1 & 3 & 53 & 51 \\
\hline $41 M C 210$ & 6 & 9 & 0 & 0 & 0 & 0 & 0 & 3 & 6 \\
\hline $41 \mathrm{MC} 217$ & 5 & 2 & 0 & 0 & 0 & 0 & 0 & 1 & 2 \\
\hline $41 M C 225$ & 6 & 2 & 0 & 0 & 0 & 0 & 0 & 5 & 2 \\
\hline
\end{tabular}




\begin{tabular}{|c|c|c|c|c|c|c|c|c|c|c|}
\hline \multirow{2}{*}{$\begin{array}{l}\text { Site } \\
\text { Number }\end{array}$} & \multirow{2}{*}{$\begin{array}{l}\text { Total } \\
\text { Number } \\
\text { of } \\
\text { Flakes } \\
\end{array}$} & \multirow{2}{*}{ Utilized } & \multicolumn{2}{|c|}{ Location of } & \multicolumn{2}{|c|}{ Utilizaton } & \multirow[b]{2}{*}{ MLT } & \multirow{2}{*}{$\begin{array}{r}\text { Type } \\
\text { TRN }\end{array}$} & \multicolumn{2}{|c|}{ Utilization } \\
\hline & & & & & & & & & LON & TLG \\
\hline $47 L K 31$ & 39 & 12 & 6 & 0 & 3 & 0 & 3 & 12 & 0 & 0 \\
\hline 41LK32 & 102 & 16 & 8 & 1 & 4 & 0 & 3 & 16 & 0 & 0 \\
\hline 41LK121 & 7 & 1 & 1 & 0 & 0 & 0 & 0 & 1 & 0 & 0 \\
\hline $41 L K 152$ & 22 & 10 & 5 & 0 & 2 & 0 & 3 & 5 & 2 & 3 \\
\hline $41 L K 159$ & 63 & 11 & 6 & 0 & 3 & 0 & 2 & 11 & 0 & 0 \\
\hline 47LK171 & 18 & 4 & 3 & 0 & 0 & 0 & 1 & 3 & 1 & 0 \\
\hline $41 \mathrm{LK} 181$ & 35 & 4 & 2 & 0 & 2 & 0 & 0 & 4 & 0 & 0 \\
\hline $41 L K 183$ & 8 & 2 & l & 0 & 0 & 0 & 1 & 2 & 0 & 0 \\
\hline $41 M C 799$ & 7 & 1 & 1 & 0 & 0 & 0 & 0 & 1 & 0 & 0 \\
\hline 41 MC201 & 240 & 54 & 34 & 2 & 12 & 0 & 6 & 51 & 1 & 2 \\
\hline $47 M C 210$ & 15 & 5 & 4 & 0 & 0 & 0 & 1 & 5 & 0 & 0 \\
\hline $47 \mathrm{MC} 217$ & 7 & 2 & 0 & 0 & 2 & 0 & 0 & 2 & 0 & 0 \\
\hline 47 MC225 & 8 & 1 & 0 & 0 & 1 & 0 & 0 & 1 & 0 & 0 \\
\hline
\end{tabular}

*Key to Table 15 is on page 277. 
descriptions of flake characteristics may be found in Mayer-Oakes (1973), Chapman (1973), and Speth (1972).

There exist numerous metric and nonmetric observations which can be applied to the analysis of flakes. For example, Reeves (1970) has produced a flake attribute list which covers 53 nonmetric and 25 metric observations. At the Hop Hill site in central Texas, Gunn and Mahula (1977) analyzed flakes according to 42 categories of observation (both metric and nonmetric). Other examples can be given; it is clear that the field of lithic flake technology can be extremely complex and time consuming. Analytical procedures for flakes should be directly related to the overall project research design and its objectives. Gunn and Mahula's (1977:235-255) analytical scheme provides a great deal of descriptive data. Using only some parts of this scheme can provide desirable information with some savings in time. The format used to describe the flakes obtained from the 1977 Choke Canyon project is a greatly condensed version of the Hop Hill flake technology format. In addition to specific provenience information, nine categories of information were recorded for each collected flake.

Each flake was first categorized according to its technotype (ibid.:237). Five categories were possible: (unspecialized) flake, bifacing flake, blade, pressure flake, and indeterminant flake.

Gunn and Mahula (1977:237) have described flakes in relation to the overall lithic reduction process:

If assumptions are made relative to the order in which each

flaking technique is most probabiy used in a reduction sequence, the order is sequential from flakes to pressure flakes. Unspecialized flakes are produced in the initial stages of any flaking tasks.

Bifacing flakes retain a remnant of the biface edge from which the flake was struck. They often retain an overhanging $1 \mathrm{ip}$, but not al1 lipped flakes are bifacing flakes: The dorsal surface of the flake must exhibit portions of the face of the biface which has been flaked. For the purposes of this report, a blade is a flake which is twice as long as it is wide. Both bifacing flakes and blades occur during the overal1 1 ithic reduction process as part of ". . .refined tool making" (ibid.). Pressure flakes are flakes which have been removed from the edge of an artifact ". . .by pressure with a tool such as an antier tine" (Schaafsma 1977:184). These flakes are characteristically long, thin, and slender, with noticeable ripple marks and irregular edges. Pressure flakes are quite easily broken. Gunn and Mahula (1977) note that pressure flakes occur last in the overall lithic reduction sequence; they are the products of final shaping and finishing as well as resharpening activities. Indeterminant flakes are specimens that could not be readily identified by the anaTyst.

Flake size is the second recorded category. We used a series of rings of known diameter as a measure of flake size (its largest dimension). The ventral face of the flake was held down on the rings when determining size. Size class intervals (in mm) were the following: 0-4.49, 4.49-10,10-20, 20-40,40-80, and greater than $80 \mathrm{~mm}$. A similar measuring procedure has been used by Katz (1976), 
Gunn, Mahula, and Sol1berger (1976), and Gunn and Mahula (1977). Our intention was to observe the general size characteristics of the flake technotypes.

Dorsal surface cortication is the third flake description category. The dorsal surface may be 1) completely covered with cortex (corticated), 2) partically covered with cortex, and 3) completely lacking in cortex (decorticated). These three states provide a good indication as to the stage of lithic reduction from which the flake has been produced (cf. Lynn, Fox, and O'Malley 1977:51).

The next category of flake description indicates the kind of striking platform that still exists on the proximal end of the flake. Platforms that have not been altered are still covered with cortex. If the striking platform has been altered by the previous removal of a flake, then the platform is termed a single facet platform. Multifaceted platforms have been prepared by the previous removal of two or more flakes on the platform (ibid.) Striking platforms are often prepared by rubbing a coarse-grained rock along the striking platform. These ground striking platforms are usually rounded and rough in appearance (Gunn and Mahula 1977:238). The force of the blow to remove a flake may be too great for the striking platform, and it may be crushed or shattered. The last kind of striking platform is an indeterminant platform, when its characteristics are not observable.

The fifth category of flake characteristic describes the shape of the striking platform. This is the outline of the platform when viewed from the side. Gunn and Mahula (ibid.) describe the three kinds of platform shapes and why they are important to record:

The platforms of normal flakes and bifacing flakes are quite distinct in many cases. The reason is apparent when the relationship of the two types of flakes to their respective parent masses is examined. A core is something of a block from which a flake is removed. The angle between the outer face and the platform is about $90^{\circ}$ or a little less. A biface, on the other hand, is a lenticular mass where edge angle becomes a striking platform. The result is a triangular platform.

A curved platform shape can be found on flakes removed either from a core or a platform (Gunn and Mahula 1977:238). We experienced difficulty in distinguishing among platform shapes' although we recorded them as well as we could, we do not consider platform shape to be a reliable indication of whether a flake was detached from a core or a biface.

The sixth flake descriptive category flake termination has also been strongly influenced by Gunn and Mahula (ibid.:239-240). Five kinds of flake end (distal) terminations can be recognized: feathered, flat, s-termination, z-termination, and runoff. Normal termination is seen as feathered, where the flake gradually tapers to a fine edge at the distal end. If the fracture front encounters the end of the parent material before tapering to a feather, the termination is a runoff. Broken terminations are classified by holding the flake with the ventral face down and with the break to the right. If the break protrudes at the top, it is termed an s-termination; if it protrudes more at the bottom, it 
is a z-termination. A flat termination is self-explanatory. Gunn and Mahula (1977:240) suggest that study of terminations may help to differentiate intentionally made terminations from those caused by manufacturing accidents.

Flake utilization is the next descriptive category. All flake edges were macroscopically examined for characteristic edge damage resulting from use-wear. If utilization (use-wear) did occur on a flake, the placement of the wear was indicated: it could occur on lateral edges (sides of the flake), at the proximal or distal end, at a corner or juncture of the lateral edges and either end of the flake, or it could occur at multiple locations.

The eighth category of flake description is 1ithic material. Seven 1ithic types were based on observation in Choke Canyon during the field survey. An $\mathrm{H}$ was added to the material type code if there was evidence of heat treatment (cf. Hester and Collins 1974). We use the term common brown chert to describe the medium-grained gray to reddish brown chert which is most common in the reservoir area. Coarse-grained cherts are the same basic material, but with larger, more easily detectable grains. Fine-grained chert is also the same basic material as common brown chert, but the grains are not macroscopically detectable. Other material types are a white translucent chert7ike material, quartzite, petrified wood, and other (miscellaneous).

Completeness is the last category used to describe flakes in our analysis. A flake is considered complete if it has a striking platform and feathered terminations on sides and ends. Any lateral, distal, or partial proximal snaps or terminations on a flake render it incomplete.

During the project, 571 flakes were collected from the tested sites and subsequently analyzed. Included are flakes from controlled and uncontrolled grab samples, surface collection units, and test pits.

Several general statements can be made regarding the flake collection as a whole. Interior flakes constitute the majority $(52.2 \%)$; secondary cortex flakes make up $44.7 \%$.

The flake technotype category provides some indication of whether a flake was detached from a core or a biface. If we consider the technotypes of unspecialized flakes ( 119 specimens) and bifacing flakes (297 specimens), then we can suggest that most of the flakes were probably removed from cores as opposed to bifaces. Almost half (47.5\%) of all the flakes exhibit a multifacet prepared platform; $25.4 \%$ of the flakes exhibit a single facet prepared platform. Only $16.6 \%$ of the flakes have a cortex platform, indicating that the vast majority of flakes were removed from a prepared platform. Flake size categories reflect a be11 curve, with $55.1 \%$ of the flakes being between 20 and $40 \mathrm{~mm}$ in size, $20.5 \%$ between 40 and $80 \mathrm{~mm}$, and $21.4 \%$ between 10 and $20 \mathrm{~mm}$. Very large flakes (greater than $80 \mathrm{~mm}$ ) constitute only $0.7 \%$ of the sample while very small flakes (4.49-10 mm) represent $2.3 \%$ of the flakes. Common brown (medium grain) chert and fine-grained brown chert constitute $92.3 \%$ of the sample. Of the flakes, $22.4 \%$ show evidence of utilization.

Of the flakes that show evidence of utilization (128), $57.8 \%$ showed use-wear on 1ateral edges, $23.5 \%$ on distal edges, $3.1 \%$ on proximal edges, and $15.6 \%$ on multiple locations. Transverse action (scraping) was probably done with $93.0 \%$ of 
the utilized flakes, longitudinal (cutting) action with $3.1 \%$, and both types of action with $3.9 \%$ 。

\section{Chips (457 specimens; Tables $16^{*}, 17^{*}$ )}

Chips are simply fragments of flakes which have had their proximal ends removed. These items retain flake characteristics, except that they lack a striking platform. Each item identified as a chip had the following information recorded: catalog number, specific provenience, type, size, general material type, heat treating, completeness, and utilization (edge wear).

Chip types are defined as follows: primary chips have dorsal surfaces completely covered with cortex, secondary chips have dorsal surfaces partially covered with cortex, and interior chips have no cortex on their dorsal surfaces. The amount of dorsal cortex on a chip is related to the stages of the 1 ithic reduction process (cf. Lynn, Fox, and O'Ma1ley 1977:52).

Chip size was determined by using the same graded rings used in the flake analysis; chip material types are also the same. A chip is considered incomplete if it has terminations or snaps on either lateral edge or at the distal end.

During the testing phase of the CRI survey, 457 chips were collected and subsequently analyzed. The majority $(68.5 \%)$ are interior chips, as was the case for flakes. Primary cortex chips are lowest in frequency $(3.9 \%)$, and secondary cortex chips represent $27.6 \%$ of the total. The vast majority of chips are between $10 \mathrm{~mm}$ and $40 \mathrm{~mm}$ in their maximum dimension. In general, chip attributes are similar to those observed for flakes, but there is a notable exception. Only $5.5 \%$ of the chips are classified as utilized, while $22.4 \%$ of the flakes are utilized. This suggests that flakes were more favored as a tool than were chips.

Twenty-five utilized chips were recorded from six sites in Choke Canyon. Two of these are primary cortex chips, eight are secondary cortex chips, and the remaining 15 are interior chips. Almost half of the collected specimens are from site $41 \mathrm{MC} 201$. Our data indicate that the vast majority of longitudinally utilized chips exhibit use-wear on a lateral edge.

\section{Shatter (29 specimens; Table 18)}

We have chosen to modify Schaafsma's (1977:183) term shatter to describe items, which are irregular pieces or chunks, lacking all evidence of being flakes or chips, but which are assumed to have been made by the deliberate application of force upon a core or cobble The definition used by Schaafsma combines chips with shatter, while we have separated these two items into different categories.

The 29 shatter specimens collected during the 1977 survey are generally large (some smaller specimens were collected), chunky, and irregular in shape. Modified faces are angular and smooth or very irregular and rough. One specimen is a fine-grained petrified palmwood while the remaining are chert. Two 
TABLE 16. CHIPS*

Chips were not collected from 41MC209 and 41MC214.

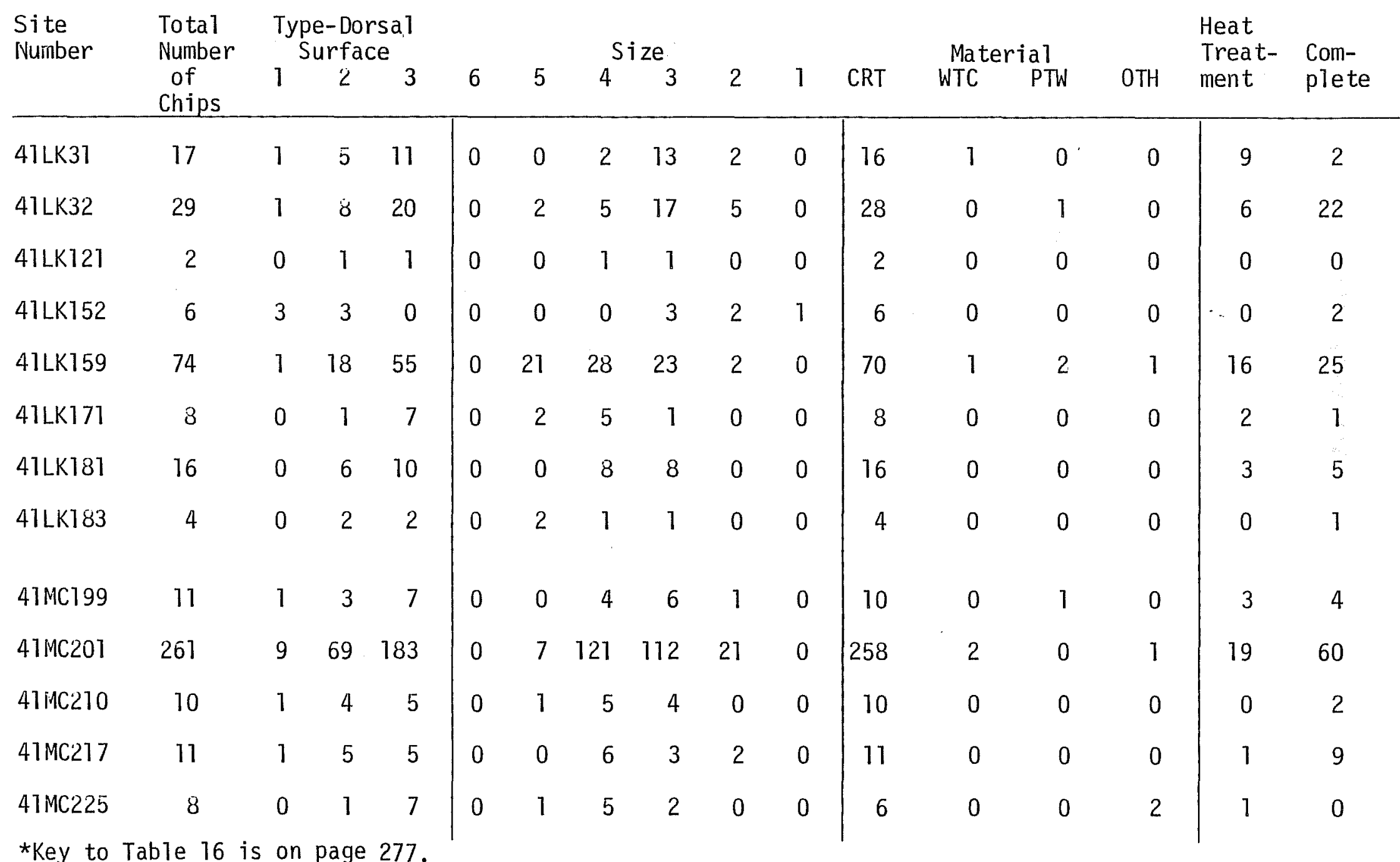




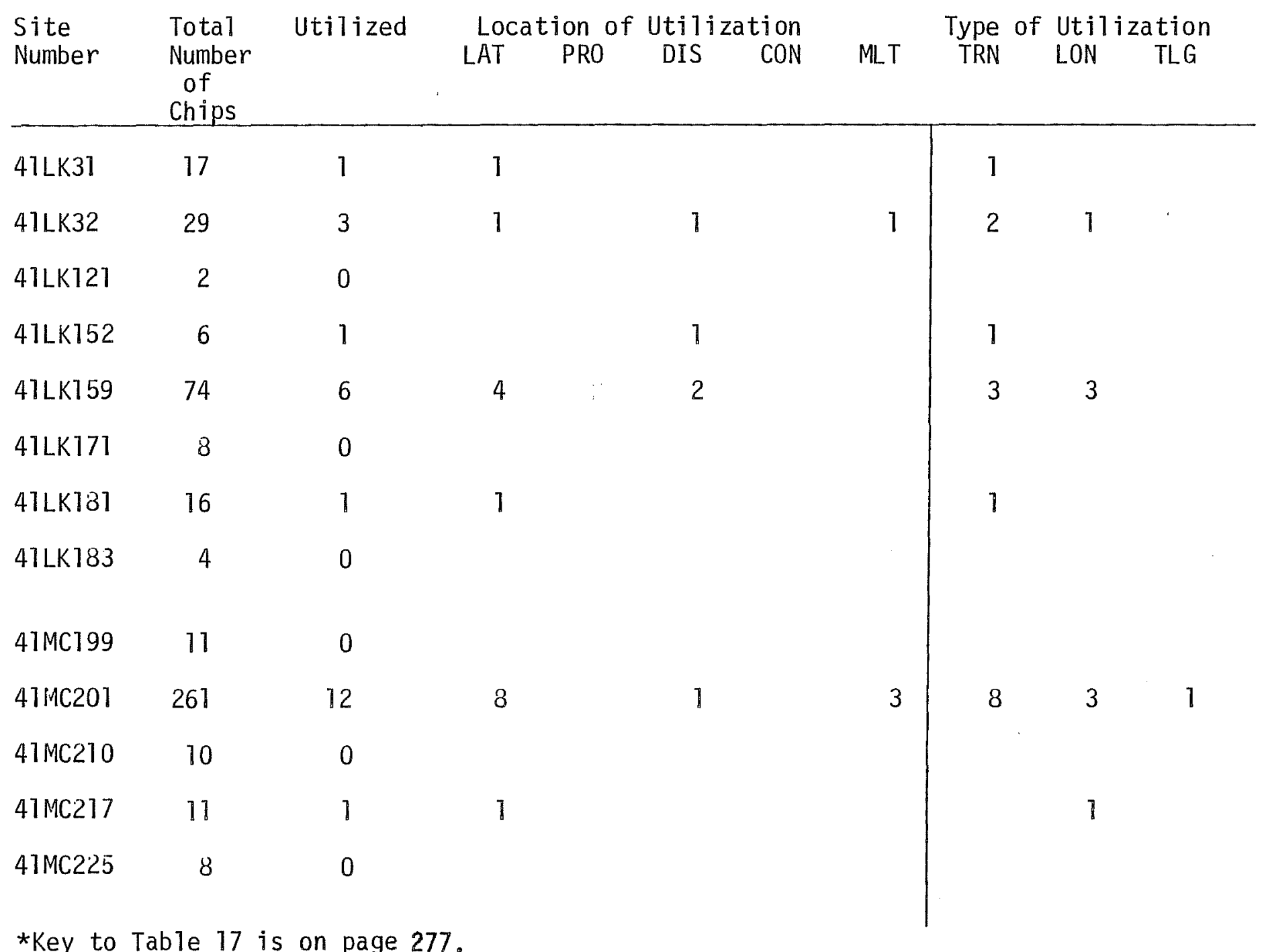


TABLE 18. LITHIC SHATTER, SPLIT COBBLES, HAMMERSTONES.

Site Number

Lithic shatter

Split cobbles

Hammerstones

41LK31

1

41LK32

4

41LK121

41LK152

7

41LK159

2

41LK171

1

41LK181

2

41LK183

41MC199

41MC201

10

1

41MC209

$41 M C 210$

1

1

$41 M C 214$

$41 M C 217$

2

41MC225 
specimens may have been subjected to heat treatment. Eight of the tested sites contain pieces of 1 ithic shatter.

Ground Stone (16 specimens, Table 19)

A11 items in this category are made from tabular medium-grained sandstone. Based on the relative curvature of the ground surface, general shape, incising, and completeness, items are placed into one of four subcategories.

GRINDING STONES (4 specimens)

Grinding stones (handstones/manos) exhibit a ground surface that is convex (Fig. 10,bb). They are thought to have been used with grinding slabs to grind or otherwise process vegetal seeds or fibers. One item is a small internal fragment (one that has been fractured on all four edges). Faint striations (probably caused by the grinding slab) are evident on the ground surface. One specimen is complete and wedge shaped in cross section, and trapezoidal in plan view. Size is: length $79.15 \mathrm{~mm}$, width $66 \mathrm{~mm}$, thickness $39.1 \mathrm{~mm}$. Another specimen is complete, ovoid in shape, and ground on one surface; two sides appear to have been shaped by chipping. Size is: length $94.1 \mathrm{~mm}$, width $75.5 \mathrm{~mm}$, thickness $33.9 \mathrm{~mm}$. The last specimen is basically ovoid in shape and shaped by chipping on two sides and on the unground face. Size is: length $125.5 \mathrm{~mm}$, width $116.5 \mathrm{~mm}$, thickness $29.25 \mathrm{~mm}$.

\section{GRINDING SLABS (5 specimens)}

Grinding slabs (metates) exhibit a ground surface that is concave or very thick in cross section (Fig. 10,ee). One specimen is a very thick (46.7 mm) edge fragment of a probable grinding slab. Another is a medial fragment of a thick $(43.65 \mathrm{~mm})$ bifacial grinding slab. Two specimens fit together to form a portion of a thin $(19.5 \mathrm{~mm})$, slightly concave grinding slab which is missing two of its four edges. Faint striations probably caused by a handstone are evident on the ground surface. Another specimen is one end of a thick (50 mm) grinding slab with oval-shaped basins on both faces. One specimen (10,ee) is an edge fragment of a relatively thin $(29.1 \mathrm{~mm})$ grinding slab which probably had a ground basin. The only complete grinding slab is long and rectanguloid in shape with elliptical-shaped basins on both surfaces. The basin on one face exhibits faint striations, probably from the action of the mano, as well as several larger and deeper striations which are partially obliterated. This suggests that a harder stone, perhaps a denticulated chert tool, was used to form the initial basin shape. The other face exhibits more of the deep striations, especially on the edge of the basin. Faint striations, probably from handstone action, are also visible. Size is: length $53 \mathrm{~cm}$, width $20 \mathrm{~cm}$, thickness $5 \mathrm{~cm}$.

\section{INCISED (4 specimens)}

These items (Fig. 10,cc,dd) exhibit grooves which have been incised into the face or edge of tabular pieces of sandstone. Tools of this nature are thought 
TABLE 19. GROUND STONE

\begin{tabular}{|c|c|c|c|c|}
\hline Site Number & Grinding stone & Grinding slab & Incised & Indeterminate \\
\hline 41 LK31 & $0 \ldots$ & & & \\
\hline 41LK32 & & & & 1 \\
\hline 41LK121 & $0 \ldots$ & & & \\
\hline 41LK15: & $0 \ldots$ & & & \\
\hline $41 L K 159$ & $0 \ldots$ & & & \\
\hline 41LK171 & $0 \ldots$ & & & $\therefore$ \\
\hline 41LK181 & 1 & 2 & 1 & \\
\hline 41LK183 & $0 \ldots$ & & & \\
\hline 47MC199 & $0 \ldots$ & & & \\
\hline 41 MC201 & 3 & & 3 & \\
\hline 41MC209 & & 3 & & \\
\hline $41 M C 210$ & $0 \ldots$ & & & \\
\hline $41 M C 214$ & $0 \ldots$ & & & \\
\hline $41 M C 217$ & $0 \ldots$ & & & \\
\hline 41MC225 & & & & 2 \\
\hline
\end{tabular}


to have been used to sharpen other tools such as bone awls or needles. Several also exhibit a ground face. One specimen (Fig. 10,Cc) is a small corner fragment of a relatively thick $(34.77 \mathrm{~mm})$ piece of sandstone. One face is ground flat and also exhibits four roughly parallel straight grooves Another is also a small and thinner $(30.15 \mathrm{~mm})$ corner fragment with one corner-ground face. A single straight groove is incised into the ground face. One specimen (Fig. 10, dd) is a small thin $(9.05 \mathrm{~mm})$ rectanguloid fragment with two edges missing. One face is ground (convex) and exhibits faint, perpendicular striations, probably from its use as a grinding stone. However, one unbroken edge exhibits eight grooves and notches incised into the edge; the other unbroken edge exhibits two grooves or notches. Another specimen is complete and does not exhibit a ground flat or curved surface that would suggest a function as a grinding slab or handstone. It is trapezoidal in shape. One end exhibits a groove which appears to have been incised into the sandstone. Near the edge of the other end there is a hole $(5.45 \mathrm{~mm}$ in diameter) that appears to have been bored at an angle through the face to the edge. The other edge of the same end exhibits a similar phenomenon, but the hole is much smaller and filled with compacted dirt; it may or may not be bored through, from face to edge. However, the incised groove is like those on other incised specimens. Size is: length $63.8 \mathrm{~mm}$, width $40.75 \mathrm{~mm}$, thickness $29.45 \mathrm{~mm}$.

\section{INDETERMINATE (3 specimens)}

These pieces are small and exhibit a flat ground surface, but it is not known whether they represent fragments of handstones, grinding slabs, or other kinds of ground stone. One specimen is composed of seven fragments and represents the face and a midsection of a larger piece of ground stone. Another is from the same site (41 MC 225) and same level of the BOR borrow area head pit; it may be part of the above described ground stone item. The last is composed of two fragments. It is a sma 11, relatively thick $(33.1 \mathrm{~mm})$ corner fragment exhibiting one flat ground surface. This is probably a grinding stone or mano fragment.

Hammerstones (5 specimens; Table 18)

Five cobbles exhibiting battering at one or more places were termed hammerstones. These artifacts are thought to have been used primarily as hammers in the manufacture of chipped stone tools. They may also have been used for pounding vegetal fibers or seeds. Alternatively, some of the tools in this category may have been intended for cores, but flakes could not be detached in the desired manner and this resulted in a battered edge. Considering the low number of hammerstones in the collection and the ready availability of cobbles suitable for hammerstones (this was observed during the survey and had been previously mentioned in Lynn, Fox, and O'Malley 1977), it is suggested that most cobbles used in hammering activities were subjected to minimal utilization (i.e., used once or twice for a short time) and did not develop substantial surface damage. Surface damage takes the form of numerous overlapping cones and step scars, resulting in an angular, rough texture.

Shape and material vary considerably among tools in this category. Three hammerstones are tabular in cross section. One specimen is ovoid in plan view, 
made from a fine-grained dark brown chert, and exhibits battering on one end which resulted in the removal of several flakes. Another is made from common grainy brown chert and is crescent shaped in plan view. It exhibits battering on both ends; the battering at one end resulted in the detachment of flakes from both faces. The third tabular hammerstone specimen is discoid in plan view and made from a coarse-grained purple quartzite. It is the smallest of the hammerstones in the collection, and most of the edge appears to have been battered. Two hammerstones are nodular. The larger hammerstone is egg shaped and made from a coarse-grained gray quartzite. Battering occurs on one end and portions of one face near the battered end. The other specimen is blocky in shape and made from common grainy brown chert. It exhibits battering on one corner of one end and on the edges of the opposite end where battering is concentrated at one corner. Size ranges are: length 50.00-137.00 mm, width 44.50-82.70 mm, thickness $29.15-80.00 \mathrm{~mm}$, weight $71.6-1168.9 \mathrm{gm}$.

\section{Heat-Fractured Rock (2049 specimens; Table 20)}

Heat-fractured rock is herein employed to describe 1ithic material which is considered to have been used in the construction of hearths. Lynn, Fox, and 0'Malley (1977:89) use the term thermally altered stone to describe hearth stone. We use heat-fractured rock as a descriptive term and distinguish it from intentionally thermally altered or heat-treated lithics. The latter process is directly related to chipped stone technology. Heat treating is intended to alter 1ithic raw material by making it more amenable to chipping or perhaps to produce raw material better suited for specific tasks. House and Smith (1975:75-80) have conducted experiments and successfully distinguished between burned hearth stones and heat-treated chipped stone. Most of the heatfractured rock from the study area is chert; sandstone is also common. Caliche or argillaceous 1imestone (Lynn, Fox, and 0'Malley 1977:89) occurs much less frequently, and other materials (e.g., quartzite, petrified wood, and siltstone) are observed only rarely. The vast majority of heat-fractured rock was collected from the surface collection units at the tested sites. A small amount (less than 1\%) was excavated from test pits and, in a few cases, heat-fractured rock was collected as part of the controlled and uncontrolled grab samples to document the occurrence of a particular material type.

Our descriptions of the major material types are based on observations of relatively intact hearths which are recognizable as concentrations of heatfractured rock. The most obvious characteristic of heat-fractured rock is the red to dark gray or black color. Chert tends to spal1 and exhibit many hairline fractures. Large cobbles tend to break into amorphous, but angular pieces. We have the impression that greater heat and/or prolonged exposure to heat produces smaller and darker colored chunks. Heat-fractured sandstone is generally reddish brown in color. Apparently heat also softens sandstone and causes it to fracture into small rectangular chunks. Smaller pieces, in general, may well be the result of more intense heat or prolonged exposure to heat, as is suggested for heat-fractured chert. Heat-fractured caliche is also very distinctive. It tends to exhibit a light to dark gray color which extends we11 into the body. Apparently heat also softens caliche; after fracturing (and perhaps with weathering), the pieces tend to be more rounded in appearance than other types of heat-fractured rock. 
TABLE 20. HEAT-FRACTURED ROOCK*

\begin{tabular}{|c|c|c|c|c|c|}
\hline Site Number & Chert & Sands tone & Caliche & Other & Total weight \\
\hline $41 L K 32$ & .064 & .003 & .013 & .023 & .103 \\
\hline 41LK121 & 1.383 & 0 & .042 & .001 & 1.426 \\
\hline $41 L K 152$ & 1.751 & 0 & 0 & 0 & 1.751 \\
\hline $41 L K 171$ & .037 & .017 & .151 & .042 & .247 \\
\hline $41 L K 181$ & .749 & .174 & 2.062 & .751 & 3.736 \\
\hline $41 L K 183$ & .124 & 0 & .008 & .006 & .138 \\
\hline $41 \mathrm{MC} 209$ & & & & & not collected \\
\hline $47 M C 210$ & 1.311 & 1.102 & 0 & .062 & 2.475 \\
\hline $47 M C 274$ & 0 & 0 & 0 & 0 & 0 \\
\hline $41 \mathrm{MC} 217$ & 1.134 & .021 & 0 & .145 & 1.300 \\
\hline $41 M C 225$ & .001 & .043 & 0 & 0 & .044 \\
\hline Total weight & 17.169 & 10.717 & 2.435 & 1.467 & 31.238 \\
\hline
\end{tabular}


Heat-fractured rock comprises the majority (52.6\%) of cultura11y related materials in the Choke Canyon Reservoir area. Since our collection procedures were designed to recover all recognizable cultural items, heat-fractured rock also constitutes the major portion of the collected materials. These items were cataloged according to material type and provenience. All pieces of heatfractured chert from a particular $1-\mathrm{m}^{2}$ grid (within a $4-\mathrm{m}^{2}$ collection unit) have the same catalog number; heat-fractured sandstone chunks from the same provenience have a different catalog number. Heat-fractured rocks were described and analyzed according to material type, weight, and size. Size was measured by placing the artifacts on a sheet marked with concentric circles. The largest circle which encompassed the rock determined its size. Five categories were established as follows: 1) less than $2 \mathrm{~cm}$;2) $2-4 \mathrm{~cm}$; 3) $4-8 \mathrm{~cm}$; 4) 8-16 cm; and 5) greater than $16 \mathrm{~cm}$. A11 items of the same material and from the same provenience were then weighed to the nearest tenth of a gram. Results are presented in Table 20 .

\section{Other Lithic Materials}

SPLIT COBBLES (10 specimens; Table 18)

A variety (both in size and material) of chert cobbles has been modified by splitting in longitudinal or transverse or both directions. No evidence could be found of bulbs of force or striking platforms on the majority of the specimens. A11 faces that have not been split are covered with cortex. Faces that have been split are generally straight or angular and have not undergone subsequent modification after being split. Six of the 10 split cobbles were recovered from site 41 LK 152, a quarry site.

\section{ALTERED GRAVELS (4 specimens)}

Three pieces of small chert gravel and one piece of quartzite have been altered by the removal of one to three primary and secondary flakes. These flake removals are from one face of each item; the remainder is covered with cortex. The number of flake removals from each item, the small size of the items, and the lack of apparent use-wear al1 combine to suggest that these gravels have been naturally altered. However, many of the flake scars appear to have negative butbs of force and/or striking platforms, which suggest cultural alteration.

\section{PETRIFIED WOOD (5 specimens)}

Five tabular specimens of petrified wood, generally large in size, were collected. They exhibit large, angular fractures on one or more edges. Examination of the fractured edges failed to produce evidence of a bulb of force or striking platform. Our conclusions are that these items were altered by an unknown method (or methods). A11 specimens were recovered from site 41 LK 152 (probably a quarry). Obvious artifacts made from petrified wood have already been described in the chipped stone sections. 
UNALTERED SANDSTONE (19 specimens)

A17 items are from site 41 MC 225, test pit number 1. Judging from their color and texture, these sma11, amorphous pieces of sandstone are probably fragments from the several ground stone artifacts recovered from the test pit at 41 MC 225 . The ground stone artifacts were probably broken when the area was mechanically cleared of brush and/or during excavation and screening; alternatively, some of the fractures may be the result of natural weathering. Two of the pieces appear to be stream worn and their occurrence at the site is probably a result of natural forces. One piece was recovered from level 1, 17 pieces from level 2, and one piece is from level 3.

\section{UNALTERED GRAVELS AND COBBLES (18 specimens)}

During field operations, these specimens were thought to be cultural artifacts. Most of the items were recovered from 1/4-inch screened material from test pits at sites 41 MC 199 and 41 MC 201. A11 items were closely examined for evidence of human modification, but these specimens lacked such evidence. Eight sites are represented by our collection of unaltered gravels and cobbles. The vast majority of these chert specimens were very small gravels.

Other Materials

\section{Ceramics (1 specimen)}

One specimen of aboriginal ceramics was observed at 41 LK 176. The sherd is a thin body fragment with a dark gray paste and quartzite temper. The exterior and interior are undecorated and reddish in color.

\section{Burned Clay (7 specimens)}

These items are pinkish brown to tan in color and are irregular in size and shape. They are also fragmentary and easily broken. Most of the items were collected from 41 LK 31 . One specimen exhibited striation on one edge, but the cause of these striations cannot be determined. We agree with the earlier observations of Lynn, Fox, and O'Malley (1977:89) concerning the nature of burned clay; they attributed the occurrence of some of their burned clay specimens to recent brush-burning activities. As a matter of fact, contemporary circular burned areas (with ash stains) containing burned clay nodules were observed throughout the survey area, and we recorded these in field notes. Each site (41 LK 32, 41 LK 159, and 41 LK 171) from which burned clay was collected also contained recent brush-burning areas.

\section{Faunal Remains}

BONE (15 specimens)

Bone was collected from five sites, and all were small pieces and fragments. Cultural association of some type can be assigned to bone fragments from three 
sites. Two burned bone fragments were recovered from the surface of the historic component at 41 LK 159. Both pieces are small fragments of the articular surface of what was probably a long bone of a medium size animal, perhaps rabbit or chicken. Considering that the bone was burned, it seems reasonable to conclude that it is associated with other historic surface materials, and the animal from which the bone came was probably a food source for the recent historic inhabitants of 41 LK 159.

Bone was also excavated from two sites which are presumably aboriginal and prehistoric in nature. The test pit at site 41 MC 201 yielded one small fragment of unburned bone recovered from a level with heat-fractured rock and charcoal. This fragment is small and thick, and probably is from a large mammal. Because the bone fragment was from a level with hearth materials, it is probably associated with cultural activities, but the fact that the bone is unburned casts some doubt on this suggestion. Burned bone was also recovered from two levels of the test pit at site $41 \mathrm{MC} 225$. Level 2 produced seven tiny fragments, only one of which was burned; it is similar in nature to the one recovered from 41 MC 201. Level 3 yielded two fragments of burned bone. One is relatively thick and probably from a large animal. The other is a small hollow bone fragment, probably from a small animal. Since other cultural materials (e.g., ground stone, chipped stone, and heat-fractured rock) were recovered from the same levels, these bone fragments probaply represent cultural activities, namely processing of at least two kinds of animals.

The uncontrolled grab sample from the backdirt of the Bureau borrow area head pit at 41 LK 31 included a fragment of a partially mineralized bone that may be from a turtle. While cultural materials were recovered from the same backdirt, the relationship of the bone is unknown. Two other bone fragments which appear to be very recent were recovered from the surface and are not associated with cultural activities. One bone is complete and part of the controlled grab sample at 41 LK 121. The bone is a metatarsal of a medium-sized animal. The other bone is from the surface collection unit at $41 \mathrm{LK} 32$. It is a long bone midsection from a medium-sized animal. The other bone is from the surface collection unit at $41 \mathrm{LK} 32$. It is a long bone midsection from a medium-sized animal. Cultural association is doubtful for the bone from 41 LK 121 and 41 LK 32 due to its surface provenience and recent (unweathered) appearance.

\section{MUSSEL SHELL (84 specimens; Table 21)}

Pieces of mussel shell (Unio sp.) were surface collected from eight tested sites during the 1977 survey. The vast majority of these items were fragmentary and often fairly smal1 in size. Nineteen pieces were at 1east $90 \%$ complete, and were classified as whole specimens. These specimens all retained the articular hinge of the mussel and most, if not all, of the remaining oval shel1.

The prehistoric inhabitants of the Choke Canyon area undoubtedly utilized river mussels as a food source and extracted them from moist, muddy stream and tributary banks.

Evidence of cultural modification is suggested from the appearance of the musse? shell. A few of the specimens collected and numerous specimens observed in the field have a dull gray color instead of the natural chalky white with a multicolor sheen. Such a color change is taken to be evidence of burning, either 
TABLE 21. MUSSEL AND GASTROPOD SHELL

Site Number

$41 L K 31$

$41 L K 32$

$41 L K 121$

$47 L K 152$

$41 L K 159$

$41 \mathrm{LK} 171$

$41 L K 181$

$41 \mathrm{LK} 183$

$41 M C 199$

$41 M C 201$

41MC209

$41 M C 210$

$41 \mathrm{MC} 214$

$41 \mathrm{MC} 217$

$41 M C 225$
Mussel shell (complete and fragments)

Gastropod she11 (complete)

present; not col

13

33

5

16

7

2

0

0

011 ected

0

0

0

6
1

18

10

0

12

7

250

present; not collected

1

16

present; not collected
8
0
1
0 
to cook the river mussel prior to consumption or to dispose of the river mussel after consumption (i.e., throwing the remains of a meal into the campfire).

Two specimens recorded in the field at 41 LK 128 exhibit another kind of cultural modification. These shells have been altered by grinding one edge of the shell (one specimen) and by boring a hole into the shell (one specimen). The function(s) of these two specimenss is not known, but shells made into pendants have been previously reported from the reservoir area (cf. Lynn, Fox, and O'Ma1ley 1977:92).

\section{GASTROPOD SHELL. (324 specimens; Table 21)}

Analysis of the gastropod samples collected during the 1977 Choke Canyon Reservoir survey was aimed primarily at identifying the genus of the whole individuals represented in our collection. Size of the individuals was also recorded. An overall initial examination indicated that many Rabdotus specimens were quite large in comparison to other individuals of the same genus. A size classification was then arbitrarily established for Rabdotus specimens, with smal1 specimens being $20 \mathrm{~mm}$ or less in length and large specimens being greater than $20 \mathrm{~mm}$ in length. Length was recorded by holding each specimen with the aperture face down over a series of rings of known diameter. To be considered as a "whole" specimen, at least $75 \%$ of the she11 had to be present. Fragmentary specimens were only recorded as existing; they were not counted. A11 gastropods were recorded by their provenience within one of the $1-\mathrm{m}^{2}$ grids of a $4-\mathrm{m}^{2}$ collection unit at a particular site. Gastropods were collected from sites 41 LK 31, 41 LK 32, 41 LK 121, 41 LK 159, 41 LK 171, 41 LK 181, 41 MC 199, 41 MC 201, 41 MC 210, and 41 MC 217. No gastropods were recorded from 41 LK 152, 41 LK 183, 41 MC 209, 41 MC 214, and 41 MC 225. However, no surface collection units were used at 41 MC 209 and 41 MC 214. Examination of field notes from the survey indicates the presence of gastropods at 41 LK 183 and 41 MC 209. No gastropods were observed at 41 LK 152, 41 MC 214, and 41 MC 225. Two of these sites (41 LK 152 and 41 MC 214) are upland sites, and 41 MC 225 is presently covered in coastal Bermuda grass.

\section{Miscellaneous ( 3 specimens)}

Several other items were recorded and collected. These are unique specimens whose characteristics are described below. No analysis of these items was undertaken. A piece of yellow ochre was collected at 41 LK 32, near a large Bureau of Reclamation borrow pit. Previous archaeological reports (Lynn, Fox, and O'Malley 1977) had not documented the presence of this material in the Choke Canyon Reservoir area.

At 41 MC 201 , a fragment of wood was recovered from the third level of test pit 1. Examination of the wood fragment indicated possible initial cellular substitution with minerals, which would be expected with woody substances thought to be several thousand years old.

Another specimen was surface collected from 41 MC 201. It is a piece of soft gypsum, which probably does not occur naturally in the survey area and may have been brought to the site by an aboriginal occupant. 
Historic Artifacts

Historic artifacts or materials from the Choke Canyon study area are readily recognizable as being items of nonaboriginal manufacture. For purposes of this report, historic materials are considered to have been made by people of mainly European extraction. It is possible that such historic materials were utilized and in some cases manufactured by Native Americans under the supervision of Europeans (Tunne11 and Newcomb 1969; Scurlock and Fox 1977; Fox 1979). However, there is as yet no documented evidence of this occurring in the Choke Canyon area. Aboriginal groups undoubtedly exploited the Choke Canyon area during the Historic Period, but no definite evidence of such activity was recognized.

The objective of the historic materials analysis was multifold. We wanted to be able to date the occupation of the sites and to determine the substantive activities at those sites as well as possible. We also wanted to contribute to the body of information concerning the relationships between specific sites and the historic occupation of the reservoir area as a whole.

Historic artifacts are divided into four major material groups: metal, ceramics, glass, and other materials such as petroleum products and construction mortar. This follows the analytical scheme used by Lynn, Fox, and O'Malley (1977). Within each of the material groups there are smaller subdivisions based primarily on particular material types or on function.

\section{Metal}

In the Choke Canyon study area all items made from metal are considered to be historic in age. They are divided into four functional categories: household items (e.g., lock hasp, rake, wagon parts, farm machinery), construction items (e.g., wire, nail, hinge), ammunition (e.g., cartridges), and personal items (e.g., buttons, pens). Metal items were recovered from 41 MC 201, 41 MC 214, and 41 LK 159. Items recovered from these sites generally date during the last half of the 19th and the first half of the 20th centuries.

\section{HOUSEHOLD ITEMS}

Nine specimens from what appears to have been a cast-iron wood stove were collected from 41 MC 214. These pieces (three of which fit together) form part of the outer she11 and interior of what seems to be one stove, judging from the texture, weight, and thickness $(2.65-4.5 \mathrm{~mm})$ of the metal. One smal1 piece with a11 edges broken exhibits the molded letter "G"; another fragment, also broken on all edges, is embossed with an " $N$ " and a " $W$ " that are separate and appear to be part of two different words. Two other pieces may also be from the same stove, but they are heavier, finer textured and generally thicker than those parts more definitely associated with the stove. One of the heavier pieces is angular in shape, broken on two ends, and has a hole for a stove or machine bolt. The other piece is an edge fragment of a heavy circular item with a beveled edge; the raised, molded figure "№ 7 " occurs on the face. This item may be part of a lid covering one of the stove's burners. Four fragments that may also be pieces of a cast-iron woodburning stove or perhaps some other item were recovered from 41 LK 159. These pieces are similar in thickness 
$(3.03 .5 \mathrm{~mm})$, texture, and weight to those recovered from $41 \mathrm{MC} 214$. One of the fragments is broken on all edges, but portions of two distinct words are embossed on one surface, "ROCKW..." and "TENN ..." suggesting that the item was manufactured in Rockw... Tennessee.

A variety of kitchen utensils was collected from 41 MC 214. These were: 1) the handleless half of a cast-iron skillet (about $20 \mathrm{~cm}$ in diameter, $5 \mathrm{~mm}$ high, and $2.6 \mathrm{~mm}$ thick); 2) about one-fifth of a cast-iron Dutch oven with legs (about $26 \mathrm{~cm}$ in diameter, $11 \mathrm{~cm}$ high, and $6.05 \mathrm{~mm}$ thick); 3) about half of a cast-iron tea kettle in two parts (about $23 \mathrm{~cm}$ in diameter, with a $15-\mathrm{cm}$ opening in the top, $12 \mathrm{~cm}$ deep, and $3.85 \mathrm{~mm}$ thick); 4) a smal1 portion of the edge or rim of a cast-iron skillet that was about $8.2 \mathrm{~cm}$ high, $3.85 \mathrm{~cm}$ thick; and 5) a tin pitcher with soldered seams and handle, about $22 \mathrm{~cm}$ high and $14 \mathrm{~cm}$ wide near the base.

Tin cans and fragments occurred at 41 MC 214 and 41 LK 159. A11 tin cans from 41 MC 214 exhibit soldered seams. One retains the "hole-in-top" and three others and their associated fragments exhibit similar characteristics on the overlapping soldered seams and/or a soldered and fitted top and bottom. Judging from the more complete specimens, these cans were about $12 \mathrm{~cm}$ high and $10 \mathrm{~cm}$ in diameter. Allowing for some distortion, these are probabiy No. $21 / 2$ or 3 cans (Fontana and Greenleaf 1962:73). Two of these tin cans have been modified by making two holes (one near the seam) on opposite sides of one end and adding a ferrous wire handle. Another specimen is similar in size and has a fitted bottom, but the top is rolled and a handle appears to have been soldered to the seams (which are folded). A smaller tin can measuring about $8 \mathrm{~cm}$ high and $4.5 \mathrm{~cm}$ in diameter exhibits overlapping seams and a fitted bottom, all of which are soldered. The top, however, has an embossed ring which was intended to accommodate a removable $1 \mathrm{id}$. One tin can is large, measuring about $24 \mathrm{~cm}$ high and $18 \mathrm{~cm}$ in diameter; it exhibits overlapping seams. One end is missing and the other was soldered but has been modified (rounded inward) to facilitate attaching a secondary ferrous wire handle. There is also a small nail hole near the top. The remaining tin can collected from 41 MC 214 is a large lard can with overlapping seams and a fitted base, all of which are soldered. Attachments for a wire handle are soldered on opposite seams. This can is unusual in that it was presumably made from seven pieces of metal: two for the sides, as opposed to the more usual one-sided piece; two for the handle attachments; one each for the top (missing) and bottom; and probably a one-piece wire handle. This can is embossed with an oval, within which occur a balance, a star, and the words "ANGLO AMERICAN PACKING \& PROVISION CO., TRADE MARK, PURE REFINED LARD." The soldered-seam tin cans, including the "hole-in-top" type, were invented in 1810 and lasted until the 1900s, but seemed to have been most popular in the United States from the 1860s to the early 1900s; by 1922 the modern open-top tin can had come into general acceptance (ibid.:68-73). A11 49 tin can fragments from 41 LK 159 lack evidence of soldering and appear to be the modern "open-top" tin can.

\section{FARM/RANCH EQUIPMENT}

This is in part a catchall category for items which could not be readily identified. Items from 41 MC 214 include 1) a wrought-iron lock hoop; 2) a wroughtiron tine from a rake or pitch fork; 3 ) a heavy metal (cast-iron) ring measuring 
$10.6 \mathrm{~cm}$ in diameter, $5.2 \mathrm{~cm}$ in height, $1 \mathrm{~cm}$ thick at one end and $.65 \mathrm{~cm}$ at the other end (this item may be part of a wagon wheel assembly); and 4) five small, flat, angular pieces of thin, tinlike metal, four of which were perforated during manufacture and one of which exhibits a nail hole. While these items may be pieces of farm machinery, their function is unknown and they might be classified as household items. A similar piece of thin metal exhibiting a metal stud bradded to the flat piece was recovered from 41 LK 159, and its function is also unknown. A tinlike piece that appears to be manufactured to cover the end of a piece of leather (harness or bridle?) was also collected from 41 LK 159. None of these items is readily identifiable.

\section{CONSTRUCTION ITEMS}

Three items from 41 MC 214 are placed in this category. One piece of heavy and twisted ribbon wire measuring $1.05 \mathrm{~m}$ in length, $1.54 \mathrm{~cm}$ in width, and $2.4 \mathrm{~mm}$ in thickness was collected from the site. The wire was probably used to construct a fence for livestock. This type of ribbon wire is most similar to BrinkMartelle barbed wire. It consisted of a single strand of round barbed wire stretched longitudinally with a smooth strand of twisted ribbon wire to form a single strand. The Brink-Martelle barbed wire was patented in 1885, but was apparently never widely distributed (McCal7um and McCal7um 1965:265-266). Except for the lack of attached barbs, which could have fallen or rusted off, the twisted ribbon wire from 41 MC 201 is like the Brink-Twist barbed ribbon wire.

The Brink-Twist wire was patented in 1879 and was seemingly more popular than its successor, the Brink-Martelle type (ibid.:255-256). This type of ribbon wire was designed by Jacob and Warren M. Brinckerhoff of Auburn, New York. It was stocked in south Texas hardware stores shortly after 1881 (McCallum and McCa11um 1965:149).

The only square nail collected during the entire project came from inside the main structure at 41 MC 274. It is too bad7y rusted and burned to measure or describe in detail. The remaining item is a rectangular three-hole (each side), wrought-iron door hinge similar to those that can be purchased today at any hardware store.

\section{AMMUNITION}

Ammunition was recovered from 41 MC 201, 41 MC 214, and 41 LK 159. A .44 caliber spent cartridge with a headstamp "W.R.A. CO, .44, W.C.F." was recovered from 41 MC 214. This cartridge was used for the Model 1873 Winchester rifle and the Colt single-action revolver manufactured by the Winchester Repeating Arms Company of New Haven, Connecticut (Logan 1959:137). Another spent cartridge was collected from $41 \mathrm{MC} 201$ (which is within $300 \mathrm{~m}$ of $41 \mathrm{MC} 214$ ). It lacks a headstamp and is badly damaged but is similar to several .44 caliber cartridges patented between 1869 and 1875 (ibid.:90-91, 136-138). Presumably both .44 caliber cartridges could have been fired from the same revolver. A .30 caliber spent rifle cartridge with the headstamp "PETERS, .30 U.S.G." and a stainless steel primer was collected from 41 LK 159. This artifact was made some time after the introduction of the noncorrosive primer in 1927 (Moore 1963:74-75). 


\section{PERSONAL ITEMS}

Items placed in this category from 41 MC 214 were two small keyhole covers. One is very smal1, made from thin iron (probably wrought), and shaped to fit into a box (possibly a jewelry box) enclosing the locking mechanism. It exhibits two slightly inset holes, probably for nails or screws, and one keyhole-shaped hole in the center. This artifact may have been for use on a larger box or perhaps a drawer. A we11-worn Lincoln penny dated 191? was collected from 41 LK 159, as well as a metal four-hole button measuring $1.74 \mathrm{~cm}$ in diameter. The remaining specimen is a nonferrous short, tubelike fitting, that was probably part of a bal1-point pen or mechanical pencil. It was collected from 41 LK 159.

\section{Ceramic}

Most of the ceramic items collected during the project are small fragments which lack maker's marks and are too small to provide reliable, finely bracketed dates. In order to allow for easy comparability among the various Choke Canyon studies, the type collection established during the Lynn, Fox, and O'Malley (1977) study was used to classify our ceramics. Ceramics are divided into four material categories: 1) terra-cotta, 2) stoneware, 3) earthenware, and 4) porcelain. Ceramic artifacts were collected from only two sites, 41 MC 214 and 41 LK 159. A11 items which could be assigned a range of dates fal1 within the last quarter of the 19th century and the first half of the 20th century.

\section{TERRA-COTTA}

Terra-cotta is a low-fired, unglazed pottery (Memmott 1971:243) which is generally reddish in color and commonly used for floor and roof tiles. Three pieces of reddish brown terra-cotta that are probabiy fragments of roofing tiles were collected from 41 LK 759 . The one piece large enough to determine its morphology is a medial fragment, with a11 sides broken. It is rectangular in cross section. One surface is smooth and one is corrugated. The corrugated surface exhibits a series of parallel ribs about $1.5 \mathrm{~cm}$ wide and $3 \mathrm{~mm}$ high. Ribs are separated by a distance of $7 \mathrm{~mm}$.

\section{STONEWARE}

For purposes of this report, stoneware is considered to be a ware which is thicker and has a softer paste than earthenware (it is easily cut or scratched with a knife blade). The paste is usually pinkish or dark gray in color. Stoneware sherds in this collection are primarily from large containers with flat bottoms, such as jugs or storage vessels.

\section{Salt-Glazed Exterior}

A11 sherds in this groups are from 41 MC 214. Two wheel-turned sherds which are part of the base and body clearly fall into this group. One of the sherds is slightly burned. They exhibit a very glossy brown-slipped (resembling 
Albany) interior and a salt-glazed exterior with an orange peel texture (Schuetz 1969:23-24). The paste is soft and pinkish brown in color. One other body/base sherd is similar in size and shape, but is too badly burned to discern the type of surface treatment. It is similar in shape and thickness to the burned body/base sherd with a brown interior slip and a salt-glazed exterior; it could be part of the same vessel. Three burned body sherds also have the brown-slipped interior and the salt-glazed exterior. Judging from the thickness of the body sherds, they may be from the same vessel as the burned body/ base sherd. If so, two vessels are represented in the collection. This type of ware is similar to that described from the Elmendorf kiln near Berg's Mi11, Texas. The Elmendorf kiln was producing utility ware from 1885 to 1916 or 1917 (ibid.:23). Al1 sherds in this group are from straight-walled vessels. The base sherds are uniform in curvature and indicate that the vessels were flat bottomed and about $17.5 \mathrm{~cm}$ in diameter.

Another wheel-turned specimen is burned and has the same provenience as the above sherds. This specimen has a salt-glazed exterior and the interior is similar to that of one of the burned sherds with a brown-slipped interior. The exterior is stamped (in indented letters) with I. SUTT or SUTL. The stamp may be part of the word Suttles. The Suttles kiln operated at La Vernia, Texas, from 1872 to 1910 , producing utility wares with a salt-glazed exterior and a terra-cotta colored interior that "looks like an unfired red clay slip" (Schuetz 1969:24). However, considering the fragmentary and burned condition, it can only be suggested that this sherd might have been manufactured at the Suttles kiln.

\section{Bristol-Glazed Exterior}

The single body fragment under this heading is from 41 LK 159. It resembles the Bristol glaze (opaque, glossy white to cream colored) (ibid.:23) below the shoulder. The shoulder itself is unglazed and above the shoulder is a brown slip which also occurs over the interior portion of the sherd. In comparison (with the specimens in the type collection), it is very much like the BristolGlazed Exterior jug which was manufactured by the Western Stoneware Company of Monmouth, I1linois after 1900 (Lynn, Fox, and O'Malley 1977).

\section{Brown Glaze Exterior}

One small body sherd is from 41 LK 159 . The sherd is thin and exhibits a brown glossy slip on the exterior and a lighter brown or tan slip on the interior. The paste is very soft and pink in color.

Another fragment is a rim/neck sherd with a light brown, almost gold-colored glaze on the exterior and portions of the interior. The lower portion of the interior exhibits a clear glaze. The size and shape of this sherd are similar to those of the ginger beer bottles described by Schuetz (1969:26) which were manufactured in Scottand and were in use from the 1860s to the 1880s. 


\section{Alkaline-Glazed Exterior}

The rim sherd and one body sherd under this heading are from 41 MC 214 . These sherds are identical to those in the type collection and have an alkaline glaze which exhibits the "characteristic green glassy surface and crackling" (Lynn, Fox, and O'Ma7ley 1977:195). The paste and surfaces are enough alike to have come from the same vesse1. Based on the curvature of the rim and body sherds, the vessel was a large bowl. Dates were not available for this type of ware.

\section{EARTHENWARE}

In this report, earthenware is considered to be a ware that is generally thinner and harder than stoneware. Earthenwares are usually glazed, and with time both faces tend to exhibit significantly more crazing than do stoneware glazes. The paste tends to be white or lighter in color than that of stoneware; it is also harder (difficult to cut or scratch with a knife). Most of the earthenware in this collection represents plates, cups, and saucers.

\section{Solid Glazed}

One bowl sherd from 41 MC 214 has a cream-colored or light tan paste. The exterior has a clear glaze on a decorated (embossed) outer surface and a white glaze on the interior surface. The other specimen (two sherds which fit together) is a plate rim sherd from 41 LK 159 . It has a white paste and exhibits a green glaze on both surfaces. Like the specimen described by Lynn, Fox, and O'Malley (1977:188), it has a molded rim and as a result appears to be banded because of variations in hue.

\section{Clear, Embossed}

Two specimens are described under this heading. One is a vertical handle to a cup or small serving bowl. The other specimen is badly burned but appears to be a horizontal handle from a serving bowl. Both have a white paste and clear glaze. The embossed designs are narrow parallel ridges separated by shallow grooves. These artifacts are from 41 MC 214.

\section{Hand-Painted Geometric}

A11 sherds in this group appear to be from the same large-mouthed jar (about $6 \mathrm{~cm}$ in diameter). The paste is white and very hard. A thick clear glaze has been applied to both surfaces. The one rim sherd has a raised lip and is void of designs, as are three of the body sherds. Ten of the body sherds exhibit blue-green lines applied under the glaze. The pieces are too fragmentary to determine the motif, but the general design is one of parallel lines, some of which are connected by diagonal lines. Onty one specimen exhibits a curved Tine. The lines' edges are diffused and the hue varies, even within a given 1ine. Similar sherds have not been reported from the Choke Canyon area, and neither a date nor source of manufacture can be assigned. However, we would guess that the vessel is Mexican in origin. 


\section{Clear, undecorated}

All items in this group have a white paste and a clear glaze applied to both surfaces. Three specimens are fragments of plates, and two of these are badly burned. Two are base sherds from plates. One exhibits a small portion of a shield design maker's mark. The other is badly burned, but retains a portion of a shield design maker's mark like that on the unburned specimen. The maker's mark on the burned sherd is also stamped with the word "CHINA." However, we were not able to identify this maker's mark. Another sherd is part of the rim of a heavy serving dish. All of the above sherds as well as two cup fragments are from 41 MC 214.

Three clear glaze, undecorated sherds were collected from 41 LK 159. They appear to be fragments of the same cup.

\section{Porcelain}

Porcelain sherds from the collection have a very hard white paste and a clear glaze applied to both surfaces. All porcelain sherds are from 41 LK 759 . One sherd is a portion of the base of a saucer. Another sherd exhibits a stamped maker's mark, "MADE IN GERMANY." This type of maker's mark is reported on porcelain manufactured in the the 20th century (Schuetz 1969:22). One of the sherds is a very small piece that could be from any part of a plate, saucer, or cup. Part of a transfer-printed pink rose occurs on the exterior of the remaining porcelain sherd. This sherd is probably part of a cup, judging from its curvature. Considering the thickness, texture, paste, and glaze of the procelain sherds, all could easily be from the same set.

\section{Glass}

A total of 92 glass artifacts were surface collected from two sites, 41 LK 159 and 41 MC 214, plus one isolated find (I-1). The majority of these items were from cylindrical bottles and jars. Our analysis will follow the glass descriptions presented in the earlier Choke Canyon survey report (Lynn, Fox, and 0'Malley 1977:196-207, Appendix III), with glass color and morphology being the means for classification and discussion. Distinctive maker's marks wil1 be matched to examples in Toulouse (1971) for potential dating.

The major breakdown of the classification of glass artifacts will begin with a color classification. Within each color category, morphological characteristics will be considered for further classification. Previous occurrences, as reported from the earlier Choke Canyon survey, will also be indicated where appropriate.

\section{CLEAR}

Morphological subdivision of transparent glass ranged from flat windowpane glass to rectangular embossed specimens to curved jar basal fragments and rims. Most of these specimens were recovered from 41 LK 159. 


\section{Windowpane}

Five fragments of transparent windowpane glass were recorded and collected from 41 LK 159. A11 specimens have been subjected to heavy natural scratching and wear, and exhibit a light smoky patina. Four of the specimens are quite thick, ranging from $5.50 \mathrm{~mm}$ to $6.55 \mathrm{~mm}$ in maximum thickness. One example of thin windowpane glass, measuring $2.05 \mathrm{~mm}$ in maximum thickness, was also recorded from 41 LK 159. Thickness of the thin specimen is comparable to examples recorded at 41 MC 185 (Lynn, Fox, and 0'Malley 1977:204, Appendix III). The thickness range at 41 MC 185 has been compared to windowpane thicknesses at other sites occupied after 1850, in particular the Carrington-Covert House, the late component of Mission Concepción, and Fort Phantom Hill (Roberson 1974; Mallouf ms.; Scurlock and Fox 1977:87). Thick specimens of windowpane glass have not been previously described.

\section{Container}

One item from 41 LK 159 is a thick, large basal fragment of a transparent gallon jug or jar. The interior is completely smooth, while the exterior is embossed with a maker's mark and is covered with wavy lines, making it difficult to see through the glass bottom. Portions of the container side remain, and a name, DURAGLAS, appears on one side near the junction of the side and bottom portions. The partial remains of a number, ?628, appear on another side, opposite the name. One seam line exists around the fragment where the bottom and side portions meet, and another seam line encircles the maker's mark and extends up the side past the other seam line to the fracture of the specimen. The maker's mark is:

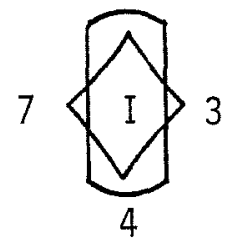

This mark was used by the Owens-I1linois Glass Company. The number 7 indicates that the Alton, I7linois plant produced this specimen, and the number 3 indicates that the production date was the third one after 1929, or 1931. However, the DURAGLAS sea1 on the side has been produced only since 1940, according to Toulouse (1971:403). A similar mark (without the DURAGLAS sea1) was recorded on a glass basal fragment from 41 MC 175 (Lynn, Fox, and 0'Malley 1977:200).

One transparent glass fragment was surface collected from 41 LK 159. A multicolored sheen patina is apparent on this artifact. The morphology of this specimen suggests that the original container was rectangular; this shape produces straight ridges and panels. This panel fragment is marked with the letters: MORDLIN. No additional markings were observed on this specimen.

Lorrain (1968:44) has noted that lettered panel bottles were initially made around 1867. Lettered panel bottles often contained patent medicines or bitters and were popular the last four decades of the 19th century (Lynn, Fox, and 0'Ma1ley 1977:200). 
Three unmarked transparent panel glass body fragments were also surface collected from 41 LK 159.

Two thin rim fragments and one thick rim fragment were surface collected from 41 LK 159. A11 are mold-manufactured transparent glass pieces of wide-mouthed jars. Rim elements of raised ribs running below and parallel to the top of the rim indicate that these fragments were originally canning jars. Lids were clamped down with wire. This attachment is called the bail-latch or lightning stopper and was initiated in 1875. Since most early jars of this type were made of light-colored glass, these clear fragments probably date much later than 1875 (Munsey 1970:146). No additional marks were observed on these specimens.

One example of a transparent body sherd exhibiting rectangular molding was surface collected from 41 LK 159 . This specimen is possibly from the broken canning jars just described.

Fourteen body fragments of transparent glass were recovered from 41 LK 159. One transparent glass body fragment was collected from 41 MC 274. A71 of the fragments collected from 41 LK 159 are slightly curved. Their spatial position (near the canning jar rim fragments) may indicate that these fragments are from the body of one or more canning jars also on the site. There is no patina on these fragments. The fragment from 41 MC 214 is irregular in shape and thickness, and has a slight seam across one side.

\section{AQUAMARINE (2 specimens)}

These items were surface collected from 41 MC 214 and are basal bottle fragments. One has an exterior seam running up from the base on the side. Previous work in Choke Canyon recorded aquamarine glass fragments from many sites in the reservoir area (Lynn, Fox, and O'Ma11ey 1977:Appendix III).

The fragments exhibit patination and contain sharp fracture lines along their interiors where the bottom of the bottle has broken. Bases are rounded and smooth. Both fragments are essentially the same thickness and look like they could have been from the same bottle, but do not fit together.

ROSE (1 specimen)

This item exhibits the straight sides of panel bottles, but it has no markings. It was collected from 41 MC 214. This fragment has three sides remaining, and is broken from the area of the panel bottle near the base, where the thickness of the glass increases and the interior surfaces begins to flare in toward the base. A multicolor sheen and patination occur primarily on the exterior bottle surface.

GREEN (17 specimens)

Three green glass body fragments and 14 burned green glass fragments were surface collected from 41 MC 214. No time diagnostic items were observed within 
the collected fragments. Previous archaeological survey work noted the presence of various kinds of green glass fragments at Choke Canyon sites 47 LK 66, 41 LK 73, 41 MC 15, 41 MC 74, 41 MC 166, and 41 MC 185.

Three fragments were surface collected from 41 MC 214, outside of the structural remains. Two specimens are thick (averaging $6.40 \mathrm{~mm}$ maximum thickness) and dark green; it is almost impossible to see through one of them. The remaining body sherd is much 1ighter in color and much thinner (about $3.0 \mathrm{~mm}$ maximum thickness). Al1 specimens are fragments of a cylindrical bottle. No other marks were observed on them. Natural scratching and abrasion and light patina were also noted on these specimens.

Three burned fragments retain enough morphological characteristics to indicate that they were once rim portions of a green glass container. Intense heat has obliterated all other details of these fragments. A11 were collected from the interior of the structural remains at 41 MC 214.

Eleven other fragments of burned green glass were recovered from within the structural remains at 41 MC 214 . Fire has reduced these items to amorphous Tumps; only their color can be determined with any certainty.

\section{PURPLE (2 specimens)}

One of these items is a rim fragment and the other is a body fragment; they came from 41 LK 159.

The curvature of the rim indicates that one specimen came from a bowl. Exterior embossing occurs below the rim and lip, but the designs are not diagnostic. An interior and exterior seam runs parallel to the top of the rim, about in the middle of the lip. Ticking occurs immediately below the rim. No other markings appear on this fragment; the interior is smooth. This artifact may be part of a candy bowl or serving dish.

The other specimen is thinner and lighter in color. Intricate floral (?) embossing appears on the exterior of this fragment, while the interior is smooth.

\section{WHITE (4 specimens)}

These specimens came from 41 LK 159. Two of them fit together. None can be considered culturally or temporally diagnostic.

Two form a portion of the base of a small white glass jar. This jar had a flat bottom, but the method of closure on the top cannot be determined from these pieces. The white glass is relatively thick and almost opaque, giving a milky appearance to the jar glass. Two exterior ribs line the base of the jar, and two exterior ribs also appear closer to the top of the jar. The interior is completely smooth. Seams were not observed.

Two other specimens are smal1 and thin with slight curvature, and both probably came from the body of a white glass container. 
AMBER (39 specimens)

Amber glass fragments were the most numerous among the collection of glass fragments. When combined with clear glass materials, more than $60 \%$ of the collection has been categorized. Seven previously recorded historic sites in the Choke Canyon Reservoir area contained examples of amber glass, with 41 MC 185 containing the greatest number and variety of specimens (Lynn, Fox, and O'Malley 1977: Appendix III). Amber glass containers generally hold light-sensitive products (Schuetz 1969:29).

One complete bottle has a narrow mouth, a flaring rim, and has been machine made, since the mold seam runs up the sides and onto the top of the rim. Volume marks (in 50-m1 increments) are embossed on one side. Seam marks indicate that this cylindrical bottle was made after 1903 (Lynn, Fox, and 0'Malley 1977:197). Given the volume markings on the side, this container probably held medicine for veterinary work, and was probably closed with a rubber or plastic stopper. A wire fragment is still attached around the rim. The bottom is marked as follows:

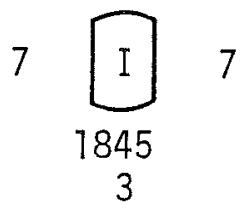

The bottle was made by the Owens-I17inois Glass Company at Alton, I11inois (Toulouse $1971: 265,403$ ). The additonal numbers below the seal make dating uncertain. This specimen was part of isolated find \#1.

Another rim fragment was also recorded in the same isolated find as the veterinary medicine bottle described above. This rim is also machine made and is morphologically similar to the rim of the complete specimen, except that it is somewhat larger in overall size, with a larger flared rim and two extra ridges beginning to run down the side of the bottle. It also has a wire fragment attached to its rim, and probably served the same purpose as the complete specimen.

One amber glass rim fragment was surface collected from $41 \mathrm{LK}$ 159. This specimen probably had a narrow mouth, much like a contemporary beer bottle. The rim lip is not prominent, and no seam was observed. A multicolor sheen patina exists on this item.

Isolated find \#1 produced two basal specimens of an amber glass bottle. One has the numeral 6 or 9 embossed on the bottle while the other is unmarked. Both have a multicolor sheen. Given their provenience (in association with the veterinary medicine bottle), these items probably came from a veterinary medicine bottle. 